DENIZE MONARIS

\title{
"Avaliação do potencial adjuvante da flagelina FliC $i$ de Salmonella enterica sorovar Thyphimurium no desenvolvimento de uma vacina contra leptospirose"
}

Dissertação apresentada ao Programa de PósGraduação Interunidades em Biotecnologia USP/Instituto Butantan/IPT, para obtenção do Título de Mestre em Biotecnologia.

\section{São Paulo}


DENIZE MONARIS

\section{"Avaliação do potencial adjuvante da flagelina FliC $i$ de Salmonella enterica sorovar Thyphimurium no desenvolvimento de uma vacina contra leptospirose"}

Dissertação apresentada ao Programa de PósGraduação Interunidades em Biotecnologia USP /Instituto Butantan/IPT, para obtenção do Título de Mestre em Biotecnologia.

Área de concentração: Biotecnologia

Orientadora:

Dra. Patrícia Antonia Estima Abreu de Aniz

Co-orientadora:

Dra. Ângela Silva Barbosa 
DADOS DE CATALOGAÇÃO NA PUBLICAÇÃO (CIP)

Serviço de Biblioteca e Informação Biomédica do

Instituto de Ciências Biomédicas da Universidade de São Paulo

(c) reprodução total

Monaris, Denize.

Avaliação do potencial adjuvante da flagelina $\mathrm{FliC} i$ de Salmonella enterica sorovar Thyphimurium no desenvolvimento de uma vacina contra leptospirose / Denize Monaris. -- São Paulo, 2010.

Orientador: Patrícia Antonia Estima Abreu de Aniz.

Dissertação (Mestrado) - Universidade de São Paulo. Instituto de Ciências Biomédicas. Programa de Pós-Graduação Interunidades em Biotecnologia USP/IPT/Instituto Butantan. Área de concentração: Biotecnologia. Linha de pesquisa: Desenvolvimento de vacinas.

Versão do título para o inglês: Evaluation adjuvant activity of Salmonella FliCi flagellin in the development of a vaccine against leptospirosis.

Descritores: 1. Leptospirose 2. Vacinas 3. Adjuvantes 4. Flagelina FliCi 5. Leptospira interrogans I. Aniz, Patrícia Antonia Estima Abreu de II. Universidade de São Paulo. Instituto de clências Biomédicas. Programa de Pós-Graduação em Biotecnologia III. Título. 


\section{UNIVERSIDADE DE SÃO PAULO}

Programa de Pós-Graduação Interunidades em Biotecnologia

Universidade de São Paulo, Instituto Butantan, Instituto de Pesquisas Tecnológicas

Candidato(a): $\quad$ Denize Monaris.

Título da Dissertação: $\quad$ Avaliação do potencial adjuvante da flagelina FliC $i$ de Salmonella enterica sorovar Thyphimurium no desenvolvimento de uma vacina contra leptospirose.

Orientador(a): $\quad$ Patrícia Antonia Estima Abreu de Aniz.

A Comissão Julgadora dos trabalhos de Defesa da Dissertação de Mestrado, em sessão pública realizada a

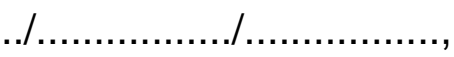
( ) Aprovado(a)
( ) Reprovado(a)

Examinador(a): Assinatura:

Nome:

Instituição:

Examinador(a): Assinatura:

Nome:

Instituição:

Presidente: $\quad$ Assinatura:

Nome:

Instituição: 


\section{FACULDADE DE MFDICINA VETERINÁRIA E ZOOTECNIA}

\section{CERTIFICADO}

Certificamos que o Projeto intitulado: "Avaliação do potencial imunogênico e vacinal de proteínas recombinantes de Leptospira interrogans, utilizando como adjuvantes a flagelina $\mathrm{FliCi}$ de Salmonella entérica sorovar Thyphimurium e hidróxido de alumínio", protocolado sob o n¹561/2008, utilizando 200 (duzentos) hamsters, sob a responsabilidade do Prof. Dr. Silvio Arruda Vasconcellos, está de acordo com os princípios éticos de experimentação animal da Comissão de Bioética da Faculdade de Medicina Veterinária e Zootecnia da Universidade de São Paulo e foi aprovado em reunião de 11/02/09.

(We certify that the Research "Evaluation of immunogenic and vaccine potential of recombinant proteins of Leptospira interrogans, using flagelin FliCi of Salmonella enterica sorovar Thyphimurium and aluminum hydroxide as adjuvants", protocol number 1561/2008, utilizing 200 (two hundred) hamsters, under the responsibility Prof. Dr. Silvio Arruda Vasconcellos, agree with Ethical Principles in Animal Research adopted by Bioethic Commission of the School of Veterinary Medicine and Zootechny of University of São Paulo and was approved in the meeting of day 02/11/09).

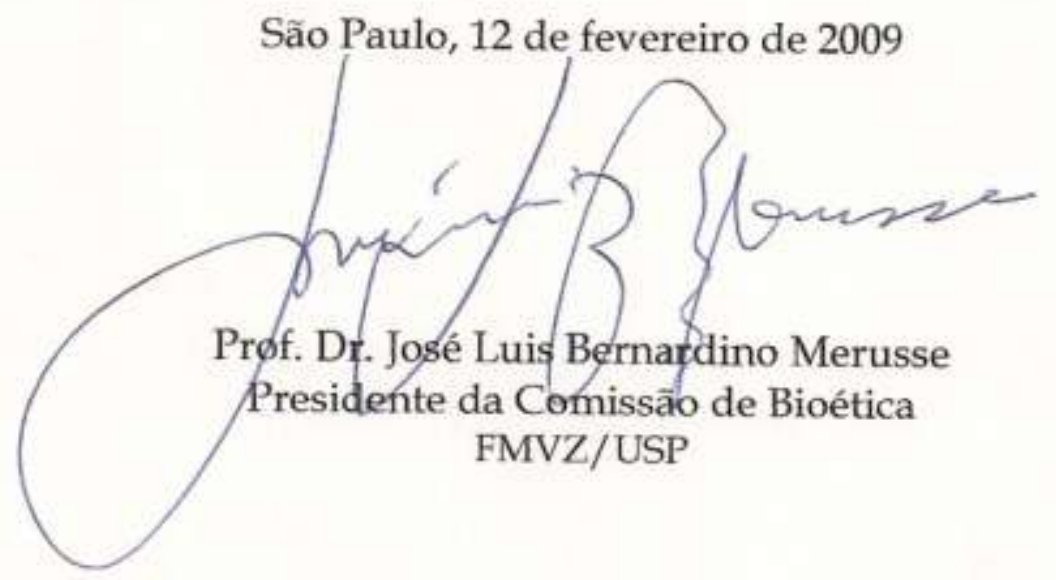


A

Comissāo de Ética em Experimentação Animal - CEEAFCF/USP

Faculdade de Ciências Farmacêuticas da USP

Senhor(a) Presidente(a),

Declaro, para os devidos fins, que o projeto do professor Dr. Silvio Arruda Vasconcellos "Avaliaçāo do potencial imunogênico e vacinal de proteínas recombinantes de Leptospira interrogans, utilizando como adjuvantes a flagelina FliCi de Salmonella enterica sorovar Thyphimurium e hidróxido de alumínio" aprovado pelo comitê de ética da Faculdade de medicina veterinária e Zootecnia da USP tem como colaboradora a prof. Dra. Patrícia Antonia Estima Abreu de Aniz, do Instituto Butantan.

Atenciosamente,

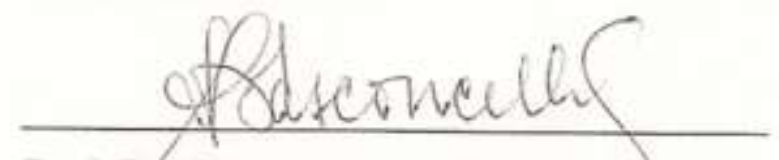

Prof. Dr. Silvio.Arruda Vasconcellos

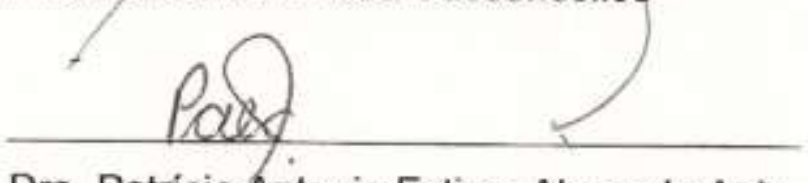

Dra. Patricia Antonia Estima Abreu de Aniz 
A Deus, as minhas orientadoras, a minha família e a Sta. Catarina de Alexandria, a quem dedico minha devoção... 


\section{AGRADECIMENTOS}

Ser Bióloga foi mais do que uma decisão, foi uma inspiração... por isso, agradeço a Deus pelos dons recebidos e a oportunidade de estudar e trabalhar no que realmente amo, pois tenho certeza de que é um trabalho muito importante e representa um pequeno passo em direção à pesquisa de uma vacina contra leptospirose.

A realização deste Mestrado foi um sonho almejado e conquistado, e neste caminho não estive sozinha, fui abençoada com pessoas capacitadas que tornaram este trabalho possível.

Com muito carinho agradeço:

Às minhas orientadoras, Dra. Patrícia A. E. Abreu de Aniz e Dra. Ângela Silva Barbosa, que me acolheram em seu laboratório, acreditaram, apostaram e incentivaram-me. Vocês são exemplo de cientistas, comprometidas e dedicadas, que ensinam e despertam o amor à pesquisa científica. E numa singela comparação digo: Assim como uma professora toma a mão de um aluno em suas primeiras lições, a Patrícia me ensinou os primeiros passos nos caminhos da Ciência e despertou, em mim, o gosto do trabalho na bancada de um laboratório. Foi um privilégio ter conhecido e trabalhado com vocês. Muito obrigada!

À minha família... meus pais Wilson e Cleide, minhas irmãs Elaine, Márcia e Aline, meus cunhados Jaime, Adriano e Marcelo. Amo minha família, amo estar na presença deles. Com nossa convivência diária aprendi muito sobre a vida: amar e respeitar. Obrigada pela presença nos momentos especiais da minha vida.

Ao Anderson, responsável por me ensinar que o amor é um dom recíproco e incondicional e que supera obstáculos. No silêncio das palavras, sempre paciente, está ao meu lado apoiando e acreditando nos meus sonhos.

Às minhas amigas e companheiras de laboratório, Ludmila B. Silva, Karolina S. R. Nunes, Ligia P. Ricardi, Vanessa Matos, Tatiana R. Fraga, Mónica Castiblanco, Adriana Martinez, Demétria e Daniela Bastos. Sou privilegiada por estar na companhia de pessoas de bem, cada uma com seu jeito singular, que conheci e aprendi a respeitar. Formamos um grupo especial, de ótimo convívio, conversas, troca de experiências, auxílio nos trabalhos e muitas, muitas risadas. A amizade é fundamental e agradeço por fazerem parte da minha história.

Meus sinceros agradecimentos aos colaboradores deste projeto:

Ao Dr. Silvio Arruda Vasconcellos, Zenaide, Gisele e Amane do Laboratório de Epidemiologia e Zoonoses Bacterianas (FMVZ-USP), que me permitiram usar as dependências do laboratório, pela manutenção das culturas de leptospira e auxílio no trabalho com os animais. 
À Dra. Maria Elisabete Sbrogio-Almeida do Centro de Biotecnologia (Instituto Butantan) e ao Dr. Luis Carlos de Souza Ferreira do Departamento de Microbiologia (ICB-USP), que me disponibilizaram a bactéria $S$. Thyphimurium para a obtenção da flagelina FliCi.

Ao Dr. Marcelo de Franco e sua aluna Tatiane Canhamero do Laboratório de Imunogenética (Instituto Butantan) pela colaboração, uso das dependências e equipamentos do laboratório para a realização dos RTq-PCR.

À Dra. Roxane Maria F. Piazza, Dra. Elizabeth A. L. Martins e Dr. Paulo Lee Ho do Instituto Butantan, que abriram as portas e me permitiram utilizar as dependências e equipamentos de seus laboratórios, obrigada.

Ao Conselho Nacional de Desenvolvimento Científico e Tecnológico (CNPq) e a Pró-Reitoria de Pós-Graduação da USP pelo apoio financeiro.

Aos professores e funcionários do Programa Interunidades em Biotecnologia da USP por todo o ensinamento e trabalho prestado, sou muito grata.

Aos demais pesquisadores, estudantes e funcionários do Instituto Butantan que tornaram a convivência diária um grande aprendizado. 


\section{Sabedoria}

O princípio da Sabedoria é o mais sincero desejo da instrução; a preocupação com a instrução é o amor;

o amor é a observância de suas leis; a observância de suas leis é a garantia de incorruptibilidade, e a incorruptibilidade faz estar junto de Deus. (Sb 6, 17-19)

De fato, ela é mais bela que o Sol e supera todas as constelações. Comparada à luz, ela é mais brilhante: pois a luz sucede a noite, ao passo que contra a Sabedoria, o mal não prevalece. (Sb 7, 29-30)

Conhecedora da ciência de Deus é ela quem seleciona as suas obras. Se a riqueza é um bem desejável na vida, que há de mais rico do que a Sabedoria, que realiza todas as coisas? ( $\mathrm{Sb} 8,4-5)$ Assim, o desejo da Sabedoria conduz à Deus.

"A fé e a razão são as duas asas com as quais o espírito humano alça voo para contemplar a verdade" Papa João Paulo II

"A pouca ciência afasta de Deus, mas a muita ciência aproxima de Deus" 


\section{RESUMO}

MONARIS, D. Avaliação do potencial adjuvante da flagelina FliCi de Salmonella enterica sorovar Thyphimurium no desenvolvimento de uma vacina contra leptospirose. 2011. 110 f. Dissertação (Mestrado em Biotecnologia) - Instituto de Ciências Biomédicas, Universidade de São Paulo, São Paulo, 2011.

A leptospirose é uma zoonose de importância global causada por espiroquetas patogênicas do gênero Leptospira, que colonizam os túbulos renais e são liberadas ao ambiente externo pela urina. Algumas vacinas contra esta doença estão sendo usadas, porém promovem proteção apenas contra os sorovares presentes na preparação e falham em induzir imunidade de longa duração. A flagelina, proteína estrutural do flagelo bacteriano, liga-se ao receptor Toll-like 5 (TLR-5) e promove a ativação da resposta imune inata com subsequente resposta imune adaptativa. Esta proteína é considerada um adjuvante promissor para o desenvolvimento de vacinas. Este trabalho avaliou o potencial adjuvante da flagelina FliCi de Salmonella enterica sorovar Thyphimurium na indução de resposta imunoprotetora em uma formulação vacinal acelular composta pela porção C-terminal da proteína LigA (LigAc) e por seis prováveis lipoproteínas de membrana externa recombinantes de Leptospira interrogans sorovar Copenhageni como alternativa profilática para a leptospirose. As sequências codificantes de seis lipoproteínas e da LigAc foram clonadas no vetor de expressão pAE em E. coli. As proteínas recombinantes foram purificadas por cromatografia de afinidade a metal a partir da fração solúvel (Lp25, Lp21, Lp22) ou do sedimento de corpúsculos de inclusão (Lp11, Lp30, Lp35 e LigAc). A flagelina FliC $i$ foi obtida a partir do sobrenadante de cultura de S. enterica sorovar Thyphimurium precipitado com acetona. Os espectros de dicroísmo circular realizados com as proteínas purificadas e as análises feitas por gel SDS-PAGE mostraram que os protocolos de purificação estabelecidos foram adequados para a obtenção das proteínas com rendimento e pureza suficientes e estas mantiveram a conformação estrutural. Hamsters imunizados com LigAc ou LigAc co-administrada com o pool das proteínas acrescidas de FliC $i$ ou $\mathrm{Al}(\mathrm{OH})_{3}$ apresentaram altos títulos de anticorpos contra as proteínas recombinantes e foram protegidos do desafio letal (86-100\%). Os animais imunizados com o pool $+\mathrm{Al}(\mathrm{OH})_{3}$ foram parcialmente protegidos $(50 \%)$ e os animais vacinados com o pool + FliCi morreram com sintomas de leptospirose. Animais controle negativos imunizados com PBS acrescido de FliC $i$ ou $\mathrm{Al}(\mathrm{OH})_{3}$ morreram e os animais imunizados com vacina comercial, bacterina com FliC $i$ ou $\mathrm{Al}(\mathrm{OH})_{3}$ sobreviveram ao desafio (90-100\%). Somente os grupos imunizados com a 
vacina comercial, bacterina e Pool + LigAc + FliCi apresentaram redução na colonização renal (0-28\%). Dados preliminares sugerem um aumento da expressão dos genes das citocinas Th1 e Th2 nos grupos que apresentaram proteção e diminuição do número de animais portadores. Em conjunto, estes resultados demonstram que o desenvolvimento de novas formulações vacinais contra a leptospirose, utilizando proteínas recombinantes purificadas como antígenos e a flagelina FliC $i$ como adjuvante, é um caminho promissor.

Palavras-chave: Leptospira interrogans. Vacinas. Adjuvantes. Flagelina FliCi. Leptospirose. 


\begin{abstract}
MONARIS, D. Adjuvant activity of Salmonella enterica serovar Thyphimurium FliCi flagellin in the development of a subunit vaccine against leptospirosis. 2011. $110 \mathrm{p}$. Master thesis (Biotechnology) - Instituto de Ciências Biomédicas, Universidade de São Paulo, São Paulo, 2011.
\end{abstract}

Leptospirosis is a global zoonotic disease caused by pathogenic spirochetes of the genus Leptospira that colonize the renal tubules of wild and domestic animals and are excreted in the environment by their urine. The available vaccines against leptospirosis do not confer cross-protection against the leptospiral serovars not included in the preparation and induce short-term immunity. Flagellin is a structural protein of the bacterial flagellum that binds to Toll-like receptor 5 (TLR-5), eliciting the innate and subsequently the adaptative immune response. This protein is considered as a promising adjuvant in the development of vaccines. In the present study, we evaluated the adjuvant activity of Salmonella enterica FliC $i$ flagellin in the protective immunity induced by the C-terminal portion of LigA ( $\operatorname{LigAc}$ ) and also by six other novel recombinant leptospiral outer membrane lipoproteins (OMP) of Leptospira interrogans serovar Copenhageni. The coding sequences of the above-mentioned proteins were cloned in pAE vector for expression in E. coli. The recombinant 6xHis-tagged proteins were purified by nickel affinity chromatography from the soluble (Lp25, Lp21, Lp22) or the insoluble (Lp11, Lp30, Lp35 e LigAc) fraction. Native FliCi from S. enterica serovar Typhimurium was purified from culture supernatant and precipitated with acetone. Circular dichroism spectroscopy revealed that the recombinant proteins preserved their structural integrity, and high purity and yields were observed by SDS-PAGE analyses. Immunization of hamsters with LigAc or LigAc coadministered with OMPs cocktail, both with FliC $i$ or $\mathrm{Al}(\mathrm{OH})_{3}$, induced robust antibody responses against recombinant proteins, and conferred protection after challenge (90-100\%). Animals inoculated with OMPs cocktail with $\mathrm{Al}(\mathrm{OH})_{3}$ were partially protected (50\%) and those immunized with OMPs cocktail with FliC $i$ died with symptoms of leptospirosis after challenge. Control animals vaccinated with PBS with $\mathrm{Al}(\mathrm{OH})_{3}$ or FliCi died with symptoms of the disease, and hamsters vaccinated with a commercial vaccine, bacterin with $\mathrm{FliC} i$ or $\mathrm{Al}(\mathrm{OH})_{3}$ survived $(90-100 \%)$ after challenge. Moreover, only groups inoculated with the commercial vaccine, bacterin or LigAc coadministered with OMPs cocktail and FliCi as adjuvant showed reduced bacterial load in kidneys (0-28\%) with significant enhancement of gene expression of both Th1 and Th2 
cytokines. Taken together, our data pave the way for the development of novel vaccine formulations against leptospirosis, using recombinant proteins and $\mathrm{FliC} i$ as adjuvant.

Key-words: Leptospira interrogans. Vaccines. Adjuvants. FliCi flagellin. Leptospirosis. 


\section{LISTA DE FIGURAS}

Figura 1: Representação esquemática do vetor de expressão pAE.......................................31

Figura 2: Representação esquemática do plano de ensaio de imunoproteção em hamsters...41

Figura 3: Fluxograma do processo de expressão e purificação de proteínas recombinantes..48

Figura 4: Análise da purificação das proteínas recombinantes.............................................50

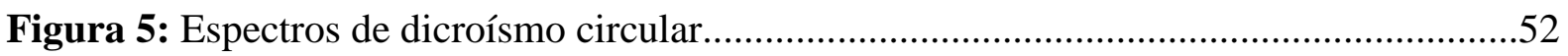

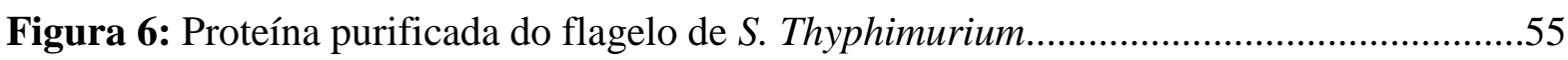

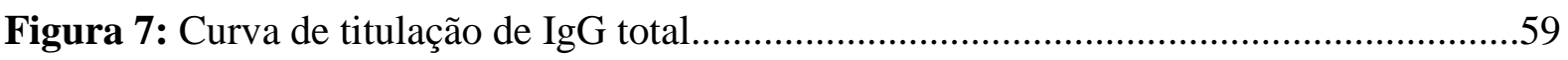

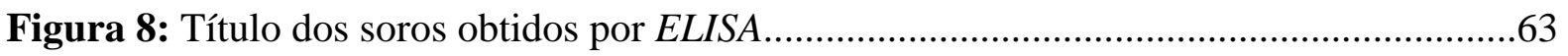

Figura 9: Valores de absorbância a 492nm obtidos por ELISA.........................................65

Figura 10: Western Blotting das proteínas recombinantes................................................66

Figura 11: Western Blotting da proteína LigAc recombinante..........................................67

Figura 12: Porcentagem de hamsters sobreviventes após desafio.....................................69

Figura 13: Macerado de rim em meio semi-sólido de Fletcher............................................72

Figura 14: Laminas histológicas coradas pela prata de corte de rins dos animais sobreviventes ao desafio. .75

Figura 15: Teste de soroaglutinação microscópica (SAM) ...............................................77

Figura 16: Teste de inibição de crescimento de leptospiras................................................. 80

Figura 17: Produtos amplificados por PCR, análise da expressão de citocinas......................82

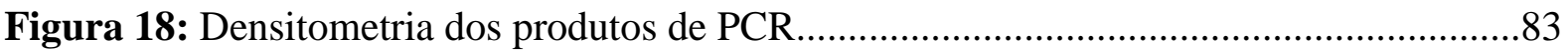

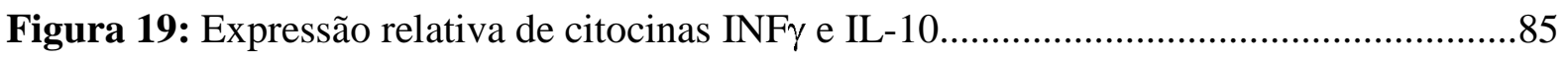




\section{LISTA DE TABELAS}

Tabela 1 - Oligonucleotídeos usados nas clonagens e acesso no GenBank............................32

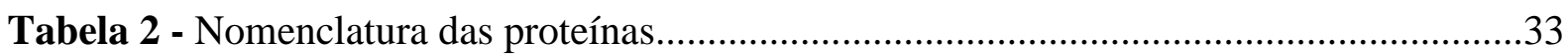

Tabela 3 - Preparação das doses para o ensaio de imunoproteção..........................................39

Tabela 4 - Oligonucleotídeos utilizados para detecção da expressão de citocinas..................46

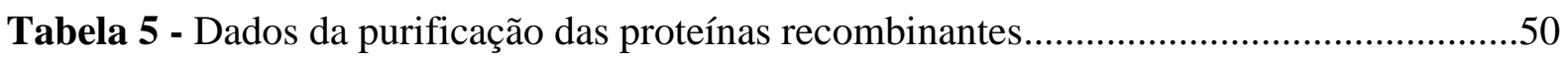

Tabela 6 - Predição teórica da estrutura secundária das proteínas recombinantes....................54

Tabela 7 - Proteção conferida pela imunização de hamsters.................................................72

Tabela 8 - Cultura do macerado do rim dos animais sobreviventes ao desafio.......................74

Tabela 9 - Resultado do teste de aglutinação microscópica................................................78

Tabela 10 - Titulação dos soros da segunda sangria de hamsters imunizados utilizando teste

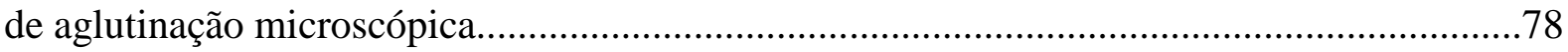

Tabela 11 - Comparação entre os animais sobreviventes em relação à colonização renal e expressão relativa dos genes de citocinas obtidos por PCR ....................................................86 


\section{LISTA DE ABREVIATURAS E SIGLAS}

\begin{tabular}{|c|c|}
\hline$\mu \mathrm{g}$ & microgramas \\
\hline$\mu 1$ & microlitros \\
\hline Abs & Absorbância \\
\hline $\mathrm{amp}$ & Ampicilina \\
\hline BSA & Albumina bovina sérica \\
\hline cDNA & DNA complementar \\
\hline $\mathrm{CD}$ & Dicroísmo circular \\
\hline DNA & Ácido Desoxirribonucléico \\
\hline DO & densidade óptica \\
\hline dNTP & deoxinucleotídeo trifosfato \\
\hline EDTA & Ácido etileno diamino tetra-ácido \\
\hline ELISA & $\begin{array}{l}\text { Enzime linked immunossorbent assay } \\
\text { (ensaio de adsorção imuno-enzimático) }\end{array}$ \\
\hline EMJH & $\begin{array}{l}\text { Ellinghausen McCullough Johnson Harris } \\
\text { (meio de cultura padrão para leptospiras) }\end{array}$ \\
\hline IFN- $\gamma$ & Interferon gama \\
\hline $\operatorname{IgE}$ & Imunoglobulina $\mathrm{E}$ \\
\hline IgG & Imunoglobulina $\mathrm{G}$ \\
\hline IL-10 & Interleucina 10 \\
\hline IL-12p40 & Interleucina $12 \mathrm{p} 40$ \\
\hline IL-4 & Interleucina 4 \\
\hline IPTG & isopropil- $\beta$-D-tiogalactosídeo \\
\hline $\mathrm{kDa}$ & kilo Dalton \\
\hline LB & Luria Bertani (meio de cultura para E. coli) \\
\hline LB-amp & Luria Bertani com ampicilina \\
\hline LIC & Leptospira interrogans sorovar Copenhageni \\
\hline Lig & leptospiral Ig-like protein \\
\hline LPS & Lipopolissacarídeo \\
\hline M & molar \\
\hline MAT & $\begin{array}{l}\text { Microscopic Agglutination Test } \\
\text { (teste de aglutinação microscópica) }\end{array}$ \\
\hline
\end{tabular}




\begin{tabular}{|c|c|}
\hline $\min$ & minuto \\
\hline $\mathrm{ml}$ & mililitros \\
\hline $\mathrm{mM}$ & milimolar \\
\hline $\mathrm{m} / \mathrm{v}$ & massa/volume \\
\hline $\mathrm{nm}$ & nanômetro \\
\hline OPD & o-dihidrocloreto de fenilenodiamina \\
\hline $\mathrm{pb}$ & pares de bases \\
\hline PBS & $\begin{array}{l}\text { Phosphate Buffer Saline } \\
\text { (tampão fosfato) }\end{array}$ \\
\hline PBS-T & Tampão fosfato contendo Tween 20 \\
\hline PBMC & $\begin{array}{l}\text { Peripheral Blood Mononuclear Cell } \\
\text { (células mononucleares do sangue periférico) }\end{array}$ \\
\hline PCR & $\begin{array}{l}\text { Polimerase Chain Reaction } \\
\text { (reação em cadeia pela polimerase) }\end{array}$ \\
\hline PMSF & Phenilmetilsulfonyl fluoride \\
\hline RNA & Ácido Ribonucléico \\
\hline RNAm & Ácido Ribonucléico mensageiro \\
\hline RT-PCR & Reação em cadeia pela polimerase via transcriptase reversa \\
\hline RT-qPCR & Reação em cadeia pela polimerase em Tempo Real \\
\hline rpm & rotações por minuto \\
\hline SDS & Dodecil sulfato de sódio \\
\hline SDS-PAGE & Eletroforese em gel de poliacrilamida contendo SDS \\
\hline seg & segundo \\
\hline $\mathrm{T} 7$ & promotor do fago $\mathrm{T} 7$ \\
\hline TAE & Tampão Tris-acetato e EDTA \\
\hline TBE & Tampão Tris-borato e EDTA \\
\hline TEMED & Tetrametiletilenodiamina \\
\hline Th1 & Célula T auxiliadora tipo 1 (T-helper 1 - resposta imune celular) \\
\hline Th2 & Célula $\mathrm{T}$ auxiliadora tipo 2 (T-helper 2 - resposta imune humoral) \\
\hline TLR-5 & Toll Like Receptor type 5 \\
\hline Tris & hidroxidometil amino-metano \\
\hline $\mathrm{V}$ & volts \\
\hline $\mathrm{v} / \mathrm{v}$ & volume/volume \\
\hline
\end{tabular}




\section{SUMÁRIO}

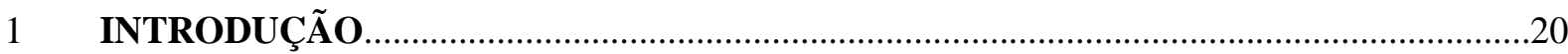

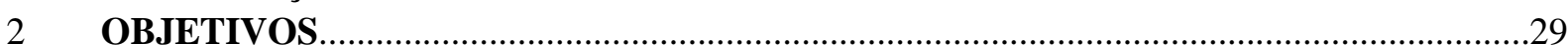

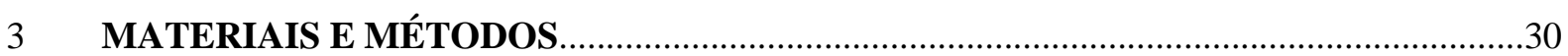

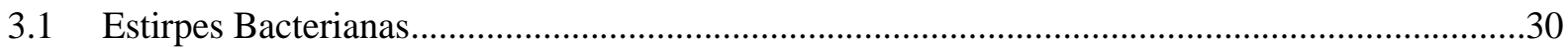

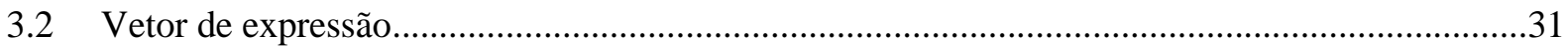

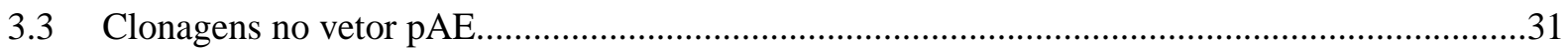

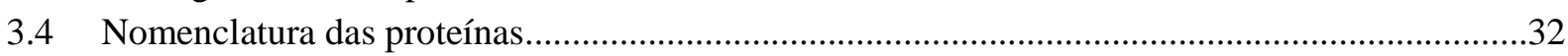

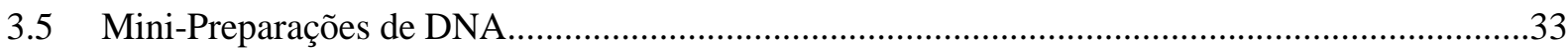

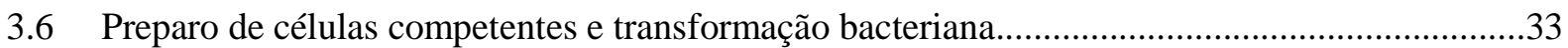

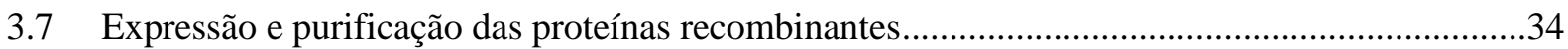

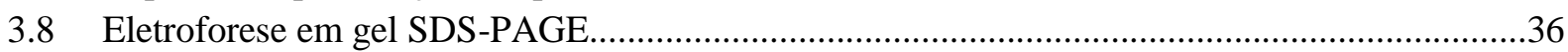

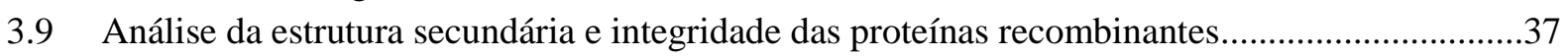

3.10 Obtenção da flagelina FliCi de Salmonella enterica sorovar Thyphimurium...............................37

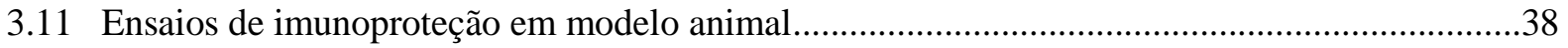

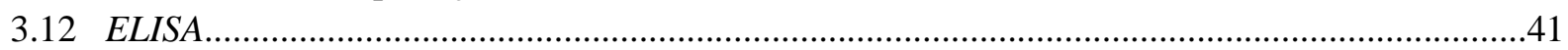

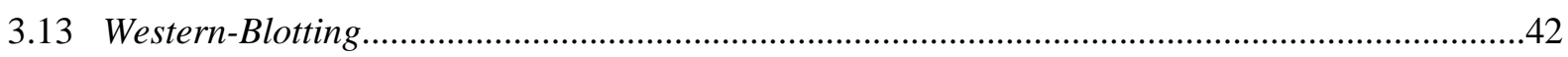

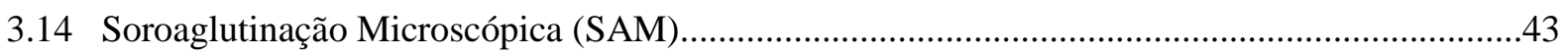

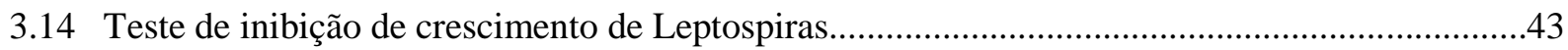

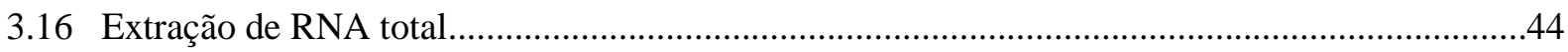

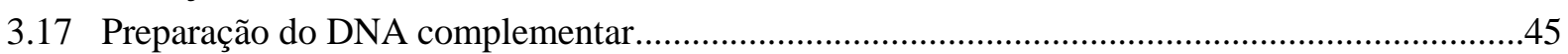

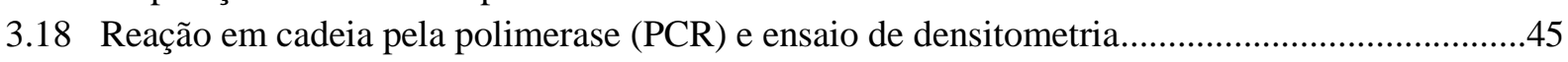

3.19 Reação em cadeia pela polimerase em Tempo Real (RT-qPCR)..............................................46

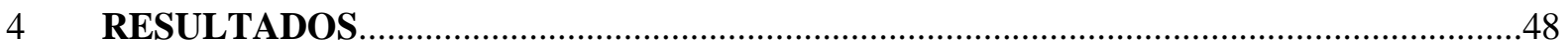

4.1 Purificação e caracterização de proteínas recombinantes............................................................48

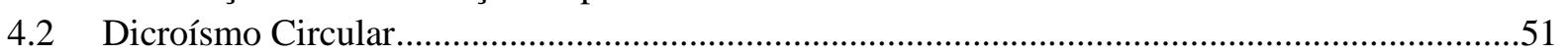

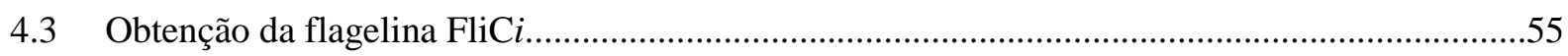

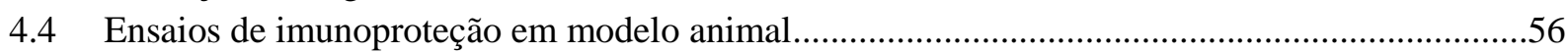

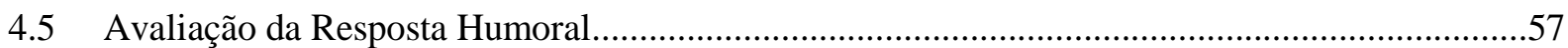

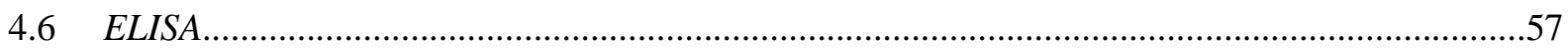

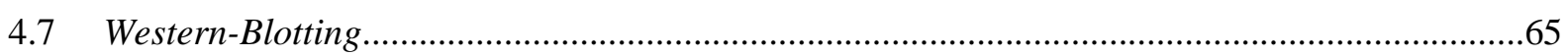

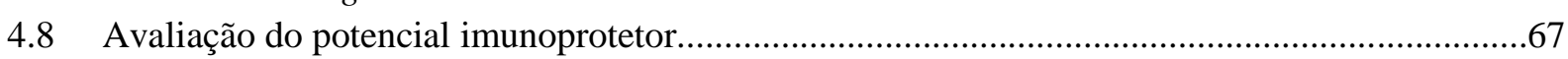

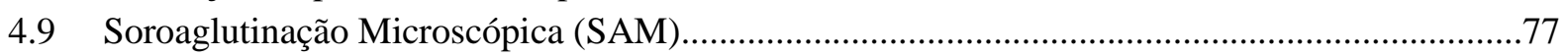

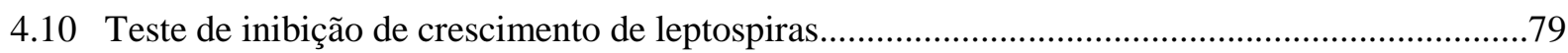

4.11 Análise da expressão dos genes de citocinas de resposta Th1/Th2 ............................................81

4.12 Comparação dos dados de sobrevivência, estado de portador renal e expressão dos genes de

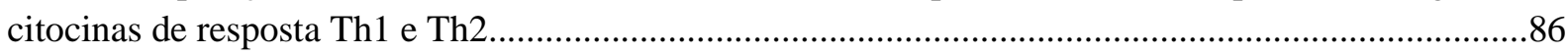

5 DISCUSSÃO

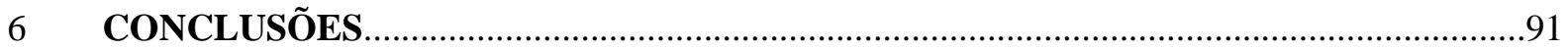

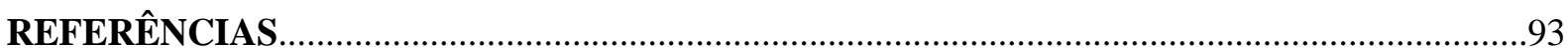

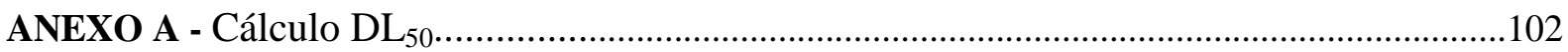

ANEXO B - Desvios-padrões das médias das curvas de titulação................................................105 


\section{INTRODUÇÃO}

A leptospirose é uma zoonose de importância mundial. É causada por espiroquetas patogênicas do gênero Leptospira, que colonizam os túbulos renais de animais silvestres ou domésticos e são liberadas no ambiente externo pela urina. A transmissão ocorre por meio de contato direto com animais infectados ou, mais frequentemente, pela exposição à água, alimentos e solo contaminados com sua urina (BHARTI et al., 2003; FARR, 1995).

Até 1989, o gênero Leptospira era dividido em duas espécies. A espécie $L$. interrogans (senso lato) que compreendia todas as estirpes patogênicas, e a L. biflexa (senso lato) com as cepas saprófitas (LEVETT, 2001). Posteriormente, o gênero foi reclassificado, com base em análises de hibridação DNA-DNA, constituindo diferentes espécies genômicas. São conhecidas oito espécies patogênicas: L. interrogans (senso estrito), L. alexanderi, L. borgpetersenii, L. kirschneri, L. noguchii, L. santarosai, L. weilii e L.alstoni; duas espécies saprófitas, como a L. biflexa (senso estrito) e a L. wolbachii e um grupo intermediário com cinco espécies, dentre as quais, a L. inadai e L.fainei, cuja patogenicidade não foi confirmada (YASUDA et al., 1987; BRENNER et al., 1999; FAINE et al., 1999; KO et al., 2009).

As leptospiras também são classificadas em sorovares definidos por reações de aglutinação após absorção dos soros com antígenos homólogos. Os sorovares antigenicamente relacionados são reunidos num mesmo sorogrupo. Existem cerca de 250 sorovares de leptospiras patogênicas e saprófitas descritos em 23 sorogrupos (FAINE et al., 1999). Esta variedade antigênica se deve à heterogeneidade da estrutura na composição do LPS (lipopolissacarídeo). A classificação fenotípica em sorovar é amplamente utilizada devido à sua importância epidemiológica e clínica, embora, não se correlacione com a classificação genética (LEVETT, 2001; ADLER e MOCTEZUMA, 2010).

Cada sorovar de leptospira está, geralmente, adaptado a uma espécie particular de hospedeiro, conhecido como hospedeiro de manutenção (reservatório). Neste, a doença manifesta-se de maneira subclínica e crônica com eliminação de leptospiras pela urina (leptospirúria) durante longo período ou por toda a vida, tornando-o a principal fonte de contaminação ambiental para as outras espécies animais, denominadas hospedeiros acidentais, que desenvolvem a forma clínica da doença (FAINE et al., 1999; KO et al., 2009).

Em áreas urbanas, os principais reservatórios de leptospiras são os roedores sinantrópicos das espécies Rattus norvegicus (rato de esgoto), Rattus rattus (rato de telhado) e Mus muscullus (camundongo). Os seres humanos são hospedeiros acidentais e a transmissão entre pessoas é rara, apesar das leptospiras serem eliminadas por vários meses após a 
infecção. A L. interrogans prevalece como a espécie que mais causa leptospirose em seres humanos em todo o mundo (LEVETT, 2001).

As bactérias do gênero Leptospira são móveis, aeróbias estritas e diferenciam-se de outras espiroquetas por possuírem a célula terminada em gancho e dois flagelos periplasmáticos (LEVETT, 2001). Não se coram bem com corantes bacteriológicos convencionais e são visualizadas utilizando-se microscópio de campo escuro ou de contraste de fase. Podem ser demonstradas nos tecidos por impregnação pela prata ou pelo emprego de imunohistoquímica (ALEXANDER et al., 1986). As leptospiras sobrevivem em solo úmido ou na água, que tenham pH neutro ou alcalino (LOMAR et al., 2000).

A incidência de leptospirose é significativamente mais alta em países tropicais do que em países de clima temperado, provavelmente porque o clima quente e úmido favorece a sobrevivência das leptospiras. A infecção em humanos está principalmente relacionada à exposições ocupacionais, recreativas e esportivas em países desenvolvidos, já que profissionais como veterinários, agricultores e trabalhadores de serviços de água e esgoto, por exemplo, ou praticantes de esportes aquáticos, podem ter contato direto com a urina de mamíferos hospedeiros (LEVETT, 2001). Em países subdesenvolvidos, a doença está diretamente relacionada às condições inadequadas de moradia, ausência de saneamento básico e à alta infestação por roedores infectados (KO et al., 1999; LOMAR et al., 2000; BHARTI et al., 2003).

No Brasil, a leptospirose é considerada um problema de saúde pública. É bastante disseminada principalmente em épocas de chuvas, pois muitas áreas estão sujeitas a alagamentos e possuem saneamento básico deficiente São relatados mais de 10.000 casos de leptospirose grave todo ano (REIS et al., 2008; SISTEMA ÚNICO DE SAÚDE, 2009). Na pecuária, a leptospirose tem causado grandes perdas econômicas por influenciar o potencial reprodutivo do rebanho. Nos bovinos, por exemplo, provoca infertilidade, mastites, abortos, natimortalidade e decréscimo na produção de leite e de carne (FAINE et al., 1999).

As leptospiras patogênicas invadem os tecidos do hospedeiro através da penetração pela pele lesada ou mucosas da boca, narina e olhos. Podem também penetrar pela pele íntegra quando imersa em água por longo tempo. Espalham-se no organismo pela corrente sanguínea e causam lesões, principalmente, no fígado e rins, onde produzem hemorragia e necrose tecidual, resultando na disfunção desses órgãos (VINETZ, 2001; FAINE et al., 1999).

As manifestações clínicas da leptospirose humana ocorrem em duas fases distintas. $\mathrm{Na}$ fase aguda ou septicêmica, o paciente apresenta febre alta, dores de cabeça, mialgias. A seguir, pode ocorrer um período com aparente melhora. Posteriormente, a fase imune inicia-se 
com o retorno do estado febril, produção de anticorpos aglutinantes e excreção de leptospiras pela urina. A maioria dos casos de leptospirose apresenta-se sob a forma leve ou moderada, cujos sintomas são os descritos para as fases aguda e imune. A leptospirose grave raramente apresenta-se bifásica. Inicia-se com sintomas bastante intensos, como dor nas panturrilhas e febre e evolui para doença ictérica com insuficiência renal e hemorragia pulmonar, representando 5 a $10 \%$ do número total de casos, podendo chegar a $40 \%$ de letalidade (LEVETT, 2001; VINETZ, 2001).

Os animais domésticos e de criação mais comumente acometidos são cães, bovinos, suínos e equinos. As manifestações da leptospirose canina são septicemia e comprometimento hepático e renal. Em bovinos e suínos, a doença séptica é mais comum em jovens, enquanto o abortamento é a principal manifestação em adultos. A uveíte recidivante é a ocorrência mais comuns em equinos (FAINE et al., 1999).

O tratamento do paciente com leptospirose é feito com antibióticos (doxiciclina e penicilinas) que reduzem as chances de evolução para a forma grave. As pessoas com leptospirose sem icterícia podem ser tratadas em casa. As que desenvolvem as formas graves da doença necessitam de internação com tratamento intensivo (BHARTI et al., 2003; LEVETT, 2003).

O diagnóstico clínico da doença não é fácil, devido à variedade de sintomas e ao fato de serem semelhantes aos de outras doenças, como febre amarela, dengue, malária, hepatite e gripe. Pode ser confirmado por meio de testes sorológicos como a aglutinação microscópica (MAT), técnica de referência indicada pela Organização Mundial da Saúde para leptospirose humana ou animal, que emprega suspensões de leptospiras vivas como antígeno (LEVETT, 2001, 2003). Normalmente, o MAT demora até duas semanas para confirmar o diagnóstico clínico da doença. O diagnóstico errado pode levar à progressão para formas mais graves, inclusive com hemorragia pulmonar, que geralmente leva os pacientes ao óbito.

O controle da leptospirose envolve medidas difíceis de serem adotadas, como a eliminação de roedores e a melhoria das condições de moradia da população. Dadas as dificuldades em se implementar tais medidas, tem havido um aumento da incidência da doença em países tropicais, o que reforça a necessidade de desenvolvimento de uma vacina eficiente (FAINE et al., 1999).

As vacinas comerciais disponíveis até o momento consistem em preparações de culturas de leptospiras de diferentes sorovares de L. interrogans inativadas pela ação do calor e/ou formol (bacterinas). São amplamente usadas na pecuária e, licenciadas para uso humano somente em Cuba, Rússia, China e Argentina. Todas apresentam baixa eficiência, pois 
promovem proteção, usualmente, contra os sorovares presentes na preparação e falham em induzir imunidade de longa duração, o que requer administração anual ou semestral (FAINE et al., 1999; BHARTI et al., 2003). Além disso, contêm uma série de contaminantes oriundos do processo de obtenção, como componentes do meio e lipopolissacarídeos (LPS), que têm sido associados aos efeitos adversos observados (LEVETT, 2001; ADLER e MOCTEZUMA, 2010).

Como alternativa, tem sido proposto o desenvolvimento de uma vacina multivalente com o emprego de proteínas de membrana de Leptospira que, além de estarem envolvidas na interação das bactérias com as células do hospedeiro, também são bastante conservadas entre as diferentes espécies e sorovares. Sonrier et al. (2000) demonstraram que extratos protéicos de L. interrogans foram capazes de induzir proteção contra diferentes sorovares, enquanto frações de lipopolissacarídeos conferiram proteção apenas contra sorovares presentes na preparação. Neste sentido, várias proteínas de membrana externa, lipoproteínas, toxinas e fatores de virulência de Leptospira spp. já foram identificadas e suas formas recombinantes têm sido avaliadas como candidatos vacinais em modelos animais (WANG et al., 2007).

Recentemente, foram sequenciados seis genomas de Leptospira spp, sendo de dois sorovares de L. interrogans (Lai e Copenhageni) (REN et al., 2003; NASCIMENTO et al., 2004a, b), de duas estirpes de L. borgpetersenii sorovar Hardjo-bovis (L550 e JB197), (BULACH et al., 2006) e de duas estirpes da espécie saprófita L. biflexa sorovar Patoc I (Paris e Ames) (PICARDEAU et al., 2008).

As análises computacionais destas sequências têm contribuído para a identificação de genes que codificam possíveis proteínas de membrana externa presentes nas espécies patogênicas, a maioria prováveis lipoproteínas que podem estar envolvidas na patogenicidade e constituem alvos potenciais para a indução de resposta imune (SETUBAL et al., 2006). As lipoproteínas bacterianas são um grupo de proteínas de membrana que possuem a cisteína amino-terminal covalentemente ligada a ácidos graxos. São sintetizadas com um peptídeo sinal, clivado por uma peptidase sinal antes da ligação covalente aos ácidos graxos. Várias lipoproteínas bacterianas já foram identificadas e caracterizadas como proteínas estruturais, enzimas, receptores, transportadores, adesinas, toxinas e com funções relacionadas com virulência (BABU e SANKARAN, 2002; SUTCLIFFE e HARRINGTON, 2004; SETUBAL et al., 2006; BARBOSA et al., 2006; VIEIRA et al., 2007; ATZINGEN et al., 2008; BARBOSA et al., 2010). Portanto, lipoproteínas bacterianas apresentam potencial para serem utilizadas como antígenos vacinais. 
O hamster e o cobaio são os modelos utilizados para os estudos da patogenia e eficiência de vacinas, pois além de serem susceptíveis à infecção, potencialmente fatal por leptospiras patogênicas, reproduzem as lesões de órgãos-alvo da leptospirose humana grave (DE BRITO et al., 1966; RANDALL e COOPER, 1944; ZEIGLER et al., 1976). Camundongos $\mathrm{C} 3 \mathrm{H} / \mathrm{HeJ}$ também têm sido utilizados na leptospirose experimental, mas não são considerados modelos ideais, pois necessitam ser inoculados com grandes quantidades de leptospiras para reproduzirem a doença e as outras linhagens de camundongos geralmente apresentam resistência à infecção (KOIZUMI et al., 2004; MCBRIDE et al., 2005).

Entre as proteínas avaliadas nesses modelos experimentais, destacam-se: a OmpL1 e a lipoproteína LipL41 que, quando expressas como proteínas de membrana em E. coli conferiram imunoproteção parcial em hamsters (HAAKE et al., 1999). A lipoproteína LipL32 também chamada proteína 1 associada à hemolisina (Hap-1) foi capaz de induzir imunidade protetora parcial em experimentos de desafio que utilizaram diferentes construções, como vacina de DNA, vacina de adenovírus e Mycobacterium bovis BCG recombinante, mas quando testada como proteína recombinante purificada não foi eficiente (HAAKE et al., 1999; BRANGER et al., 2001, 2005).

As proteínas Lig (Leptospiral immunoglobulin-like) pertencentes à família de proteínas bacterianas que se caracterizam pela presença de domínios Big repetidos, também têm sido estudadas. Três genes $\operatorname{lig}(\operatorname{lig} A, \operatorname{lig} B$ e $\operatorname{lig} C$ ) já foram descritos e só estão presentes em espécies patogênicas. $\mathrm{O}$ gene $\operatorname{lig} B$ é encontrado em várias espécies de leptospiras enquanto ligA é restrito às espécies L.interrogans e L.kirschneri e ligC é um pseudogene. (KOIZUMI e WATANABE, 2004; MATSUNAGA et al., 2003; PALANIAPPAN et al., 2002; CERQUEIRA et al., 2009).

LigA e LigB estão localizadas na membrana externa da bactéria e participam dos processos de adesão das leptospiras às células do tecido do hospedeiro (MATSUNAGA et al., 2003). Possuem as regiões amino-terminais idênticas, que correspondem a seis domínios Big (bacterial-Ig-like) repetidos, seguidas por uma região variável de, aproximadamente, sete domínios Big repetidos. LigB apresenta ainda uma região carboxi-terminal sem domínios Big repetidos (MATSUNAGA et al., 2003). São considerados os candidatos vacinais mais promissores testados até o momento. Resultados obtidos por vários grupos mostraram que estas proteínas foram capazes de induzir proteção contra leptospirose em camundongos C3H/HeJ e hamsters (KOIZUMI e WATANABE, 2004; PALANIAPPAN; RAMANUJAM; CHANG, 2007; SILVA et al., 2007; FAISAL et al., 2008; YAN et al., 2008). 
O fragmento carboxi-terminal da LigA foi capaz de conferir imunoproteção contra desafio letal em hamsters em experimentos que utilizaram a proteína recombinante com adjuvante de Freund (67 a 100\% de proteção), com hidróxido de alumínio (50\% de proteção), em sistemas carreadores formados por lipossomos (87,5\% de proteção) e microesferas (75\% de proteção). Da mesma maneira, os fragmentos amino-terminal da LigB (71\% de proteção) e carboxi-terminal da $\operatorname{LigB}$ (54\% de proteção) recombinantes com hidróxido de alumínio como adjuvantes foram capazes de induzir proteção contra leptospirose em hamsters. Entretanto, em todos estes experimentos, os animais sobreviventes foram positivos no isolamento de leptospiras em amostras dos rins e fígado, embora, estudos histopatológicos revelem menor gravidade das lesões nestes órgãos e nos pulmões dos animais experimentais quando comparados com os controles não imunizados (SILVA et al., 2007; FAISAL et al., 2008; YAN et al., 2008).

Por outro lado, estudos utilizando bacterinas preparadas a partir de culturas de $L$. interrogans sorovar Autumnalis inativadas pela ação do calor ou formol em hamsters mostraram que estas vacinas também não foram eficientes na prevenção da colonização dos rins, embora tenham apresentado altas taxas de proteção (90-100\%) e diminuição dos danos nos órgãos-alvo (SRIKRAM et al., 2008).

Todos os resultados, com base na literatura, indicam que tanto as bacterinas quanto as proteínas recombinantes testadas não foram capazes de induzir uma resposta imune adequada. Apesar de induzirem proteção, não preveniram a leptospirúria.

Os mecanismos de imunidade contra a leptospirose ainda não são completamente compreendidos. Sempre se acreditou que a resposta humoral fosse o principal mecanismo de defesa contra a leptospirose, pois as leptospiras são patógenos extracelulares e a proteção passiva já foi demonstrada em hamsters (FAINE, 1999; JOST et al., 1986). Entretanto, há relatos na literatura que indicam uma importante participação da resposta celular na imunidade adquirida contra a leptospirose.

Uma vacina comercial monovalente, contra a Leptospira borgpetersenni sorovar Hardjo testada em bovinos induziu imunidade protetora associada à resposta Th1 caracterizada por linfócitos T CD4 ${ }^{+}$e altos níveis de IFN- $\gamma$. Esta vacina foi capaz de prevenir a colonização renal e a leptospirúria (NAIMAN et al., 2001).

Além disso, tem sido especulado que as leptospiras poderiam ter uma fase intracelular rápida, durante a translocação através das monocamadas celulares, o que poderia ser um mecanismo de evasão do sistema imune e também facilitaria a entrada e saída da corrente sanguínea para infectar órgãos-alvo. A presença de leptospiras no citoplasma de macrófagos, 
monócitos e células Vero foi observada in vitro. Apesar disso, não existem evidências que estas bactérias sejam capazes de se multiplicarem no interior das células hospedeiras, o que sugere que as leptospiras sejam bactérias invasivas, mas não intracelulares facultativas (MERIEN et al., 1997; BAROCCHI et al., 2002).

Talvez a combinação de vários antígenos protéicos purificados com novas abordagens vacinais seja um caminho mais promissor para o desenvolvimento de uma vacina contra leptospirose capaz de induzir mecanismos imunológicos (humoral e celular) envolvidos na proteção e prevenção da colonização dos órgãos-alvo. Entretanto, antígenos constituídos por subunidades e proteínas recombinantes purificadas possuem baixa imunogenicidade e requerem a adição de adjuvantes para melhorar a resposta imune (RAPPUOLI, 2010).

O conhecimento dos mecanismos de imunidade Th1 e Th2 é de grande importância para a obtenção de uma vacina eficaz contra leptospirose, assim como para a compreensão da patogênese da infecção natural ou induzida.

Segundo Vernel-Pauillac (2006) a imunidade mediada por células, na defesa do hospedeiro contra a leptospirose ainda é pouco compreendida, mas estudos in vitro tem apontado a importância das citocinas no mecanismo pelo qual as leptospiras ativam o sistema imune, como por exemplo que a Leptospira induz in vitro citocinas de resposta Th1 através de células mononucleares do sangue periférico (PBMCs), e estas, apresentam vantagens em relação à células cultivadas, pois são mais representativas em relação à resposta imune in vivo. A adversidade é que a lise celular gera grandes quantidades de proteínas, necessitando assim etapas de purificação do material antes da extração do RNA total. Um método eficiente para analisar a produção de citocinas é quantificar o seu mRNA através da técnica de PCR em tempo real (RTq-PCR) (VERNEL-PAUILLAC, 2006).

A identificação e desenvolvimento de novos adjuvantes são necessários porque há poucos licenciados para uso humano, entre eles o hidróxido de alumínio que tem sido utilizado por mais de 70 anos e tem comprovada segurança. Este adjuvante induz o aumento na migração macrofágica e neutrofílica para o sítio de inoculação, explicando o fato que dentre os efeitos colaterais do seu uso temos o eritema, nódulos subcutâneos, hipersensibilidade de contato e inflamação granulomatosa. Sabe-se, também, que o hidróxido de alumínio também induz um aumento da permeabilidade vascular associado a efeito tóxico sobre macrófagos que, além de não ser eficaz com todos os antígenos porque estimula, principalmente, a imunidade humoral tornando-se deficiente na indução de resposta imune celular (RESENDE et al., 2004; RAPPUOLI, 2010). 
O sistema imune dos mamíferos é formado pela imunidade inata e adaptativa. $\mathrm{O}$ desenvolvimento adequado dos mecanismos efetores da resposta imune adaptativa (mediados por células $\mathrm{B}$, linfócitos $\mathrm{T} \mathrm{CD}^{+}$e $\mathrm{T} \mathrm{CD} 8^{+}$) depende da ativação inicial de componentes da imunidade inata. O sistema imune inato é filogeneticamente conservado e é o primeiro a ser ativado na defesa contra a infecção (JANEWAY e MEDZHITOV, 2002).

Os receptores Toll-like (TLRs) constituem uma importante família de receptores do sistema imune inato que reconhecem padrões moleculares associados aos patógenos (PAMPs). A ativação desses receptores por PAMPs induz a fagocitose e a liberação de citocinas e mediadores químicos. Estes eventos são fundamentais no desenvolvimento da resposta imune adaptativa subsequente (TAKEDA; KAISHO; AKIRA, 2003; AKIRA e TAKEDA, 2004).

As proteínas que formam o filamento do flagelo bacteriano, denominadas genericamente de flagelinas, são potentes indutores da resposta imune inata. $\mathrm{O}$ reconhecimento da flagelina ocorre, principalmente, através de sua ligação ao receptor Tolllike 5 (TLR5) encontrado na superfície de células apresentadoras de antígenos (APCs), como macrófagos e células dendríticas (ANDERSEN-NISSEN et al., 2007; STEINER, 2007).

A ligação da flagelina ao TLR5 inicia uma cascata de sinalização que resulta no recrutamento de proteínas adaptadoras, como o fator de diferenciação mielóide (MyD88), e na ativação do fator nuclear de transcrição (NF-kB) (AKIRA e TAKEDA, 2004). Estes eventos levam à ativação e maturação das APCs, incluindo o processamento e apresentação dos antígenos, aumento da expressão do complexo principal de histocompatibilidade e de moléculas reguladoras, bem como secreção de quimiocinas pro-inflamatórias e citocinas. Estas etapas são importantes para a ativação de respostas de células $\mathrm{B}$, linfócitos $\mathrm{T} \mathrm{CD}^{+}$e $\mathrm{T}$ $\mathrm{CD}^{+}$(IWASAKI e MEDZHITOV, 2004; MEDZHITOV e JANEWAY, 1999; TAKEDA; KAISHO; AKIRA, 2003).

Esse conhecimento tem sido utilizado no desenvolvimento de novas estratégias vacinais, que, coordenadamente, ligam a resposta imune inata e adaptativa, através da incorporação da flagelina nas formulações antigênicas. Resultados obtidos por vários grupos têm demonstrado que a flagelina é um adjuvante promissor capaz de aumentar a imunogenecidade e capacidade protetora do antígeno (NEWTON et al., 1989, 1991; SBROGIO-ALMEIDA et al., 2004; LEE et al., 2006; MACDONALD et al., 2007; HULEATT et al., 2008; BRAGA et al., 2008; BARGIERI et al., 2008)

Em Salmonella spp, existem três diferentes flagelinas (FliCd, FliCi e FljB) que possuem as regiões amino e carboxi-terminais conservadas e a região central variável tanto na 
sequência de aminoácidos quanto no tamanho. As regiões conservadas das flagelinas são as responsáveis pela interação com TLR5 (NEWTON et al., 1989; RAMOS; RUMBO; SIRARD, 2004b). Smith et al. (2003) demonstraram que monômeros de flagelina são muito mais potentes na indução da atividade do TLR5 do que polímeros, provavelmente porque o sitio de reconhecimento deste receptor é inacessível dentro do filamento intacto. 


\section{OBJETIVOS}

\section{Objetivo geral}

O objetivo deste projeto é avaliar o potencial adjuvante da flagelina $\mathrm{FliC} i$ de Salmonella enterica sorovar Thyphimurium na indução de resposta imunoprotetora desencadeada pela porção carboxi-terminal da proteína Leptospira immunoglobulin-Like A (LigAc) e por seis prováveis lipoproteínas de membrana externa de Leptospira interrogans sorovar Copenhageni recombinantes combinadas em uma formulação vacinal voltada para o controle profilático da leptospirose.

\section{Etapas de Trabalho}

1. Expressão e purificação das proteínas recombinantes.

2. Caracterização das proteínas recombinantes por dicroísmo circular.

3. Avaliação do potencial protetor em hamsters imunizados subcutaneamente com uma mistura de proteínas recombinantes de Leptospira purificadas, utilizando a flagelina FliC $i$ ou hidróxido de alumínio como adjuvantes.

4. Avaliação da imunogenicidade dos soros hiperimunes de hamsters por ELISA e Western Blotting.

5. Análise de soroaglutinação e soroneutralização.

6. Análise histológica de rins de hamsters.

7. Análise da expressão dos genes de citocinas de resposta Th1/Th2 por RTq-PCR em células mononucleares do sangue periférico. 


\section{MATERIAIS E MÉTODOS}

\subsection{Estirpes Bacterianas}

A Leptospira interrogans sorovar Copenhageni (Fiocruz L1-130) foi cultivada em meio EMJH modificado (Difco ${ }^{\mathrm{TM}}$ Laboratories, Sparks, Maryland, EUA) constituído por meio EMJH base $(0,23 \%)$ suplementado com $10 \%$ de soro de coelho inativado; $0,015 \%$ Lasparagina; $0,0015 \%$ piruvato de sódio; $0,001 \% \mathrm{CaCl}_{2} ; 0,001 \% \mathrm{MgCl}_{2} ; 0,03 \%$ peptona e 0,02\% extrato de carne (ALVES et al., 1996) ou em meio EMJH completo (Difco ${ }^{\text {TM }}$ Laboratories) composto por EMJH base $(0,23 \%)$ enriquecido com $10 \%$ albumina bovina, 1,25\% Tween 80, vários sais minerais e vitaminas, cuja composição completa encontra-se descrita em Haake (2006). Para o isolamento de leptospiras, a partir do macerado dos rins de animais infectados utilizou-se meio semi-sólido de Fletcher (Difco ${ }^{\mathrm{TM}}$ Laboratories). A cultura foi mantida a uma temperatura de $29{ }^{\circ} \mathrm{C}$ sem agitação. O crescimento bacteriano foi monitorado em microscópio de campo escuro e a contagem celular foi realizada em câmara de Petroff-Hausser.

A virulência desta estirpe bacteriana foi mantida através da passagem em hamsters experimentalmente infectados segundo protocolo descrito em Faine et al. (1999). Animais recém-desmamados foram inoculados intraperitonialmente com $500 \mu \mathrm{l}\left(10^{8}\right.$ células $\left./ \mathrm{mL}\right)$ de cultura de $L$. interrogans. Os animais foram monitorados diariamente para acompanhamento de sintomas clínicos de leptospirose como perda de peso, anorexia e mobilidade. Após a morte dos animais, que ocorreu entre 5-10 dias, as bactérias foram recuperadas a partir do macerado do fígado ou rim e cultivadas em meio EMJH modificado ou meio semi-sólido de Fletcher (Difco ${ }^{\mathrm{TM}}$ Laboratories) por uma passagem.

As E. coli BL21 (Novagen $^{\circledR}$, EMD Biosciences, Darmstadt, Alemanha) e BL21(DE3) foram utilizadas para expressão das proteínas recombinantes, pois possuem o gene da T7 RNA polimerase integrado ao genoma, sob o controle do promotor LacUV5, induzível por isopropil- $\beta$-D-tiogalactosídeo (IPTG). A BL21-C43 é uma estirpe mutante da $E$. coli BL21(DE3) obtida por Miroux e Walker (1996) para possibilitar a expressão de proteínas tóxicas. Estas estirpes bacterianas foram cultivadas em meio LB (1\% bacto-triptona, 0,5\% extrato de levedo, $1 \% \mathrm{NaCl}$ ) a $37^{\circ} \mathrm{C}$. 


\subsection{Vetor de expressão}

$\mathrm{O}$ vetor pAE foi desenvolvido para a expressão de proteínas heterólogas em fusão com seis resíduos de histidina na extremidade amino-terminal, o que possibilita a purificação da proteína recombinante através de colunas de afinidade a metal. Este vetor possui a origem de replicação de E.coli, promotor do fago T7, sítio de ligação ao ribossomo (RBS), códon ATG de iniciação, sequência codificante para seis histidinas, sítio de múltipla clonagem e gene de resistência a ampicilina, (Figura 1) (RAMOS et al., 2004a).

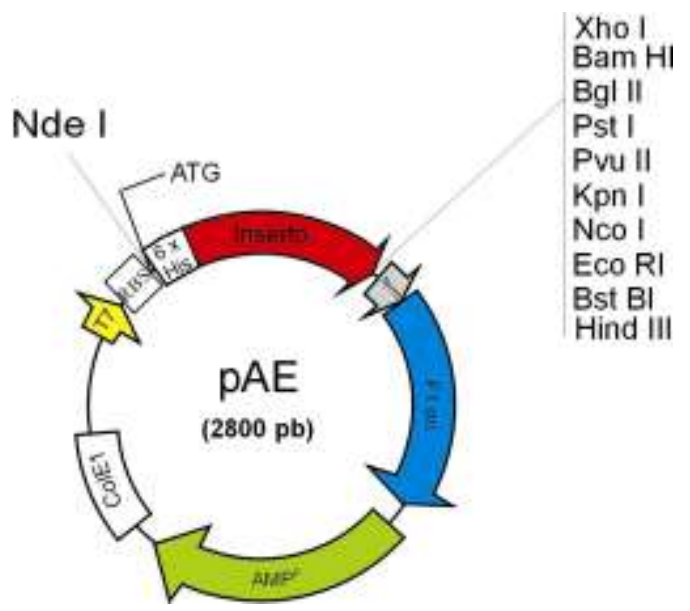

Figura 1: Representação esquemática do vetor de expressão pAE Fonte: Ramos et al. (2004a).

\subsection{Clonagens no vetor pAE}

As regiões dos genes LIC10009, LIC10301, LIC10507, LIC10704, LIC11030 e LIC11087 que codificam as sequências maduras (sem peptídeo sinal) de prováveis lipoproteínas e do gene LIC10465 correspondente à região carboxi-terminal da proteína LigA de L. interrogans sorovar Copenhageni foram clonadas no vetor pAE. O número LIC representa a nomenclatura dos genes empregada no genoma de L. interrogans sorovar Copenhageni (http://bioinfo03.ibi.unicamp.br/leptospira/).

As clonagens dos genes que codificam as prováveis lipoproteínas em pAE foram realizadas durante o projeto "Desenvolvimento de um vetor para expressão de lipoproteínas de Leptospira interrogans em Escherichia coli”, sob a coordenação da Dra. Patrícia A. E. Abreu de Aniz e a clonagem do gene LIC10465 foi realizada no projeto "Interação de 
proteínas de membrana de Leptospira com os reguladores FH e C4BP do sistema complemento humano", sob coordenação da Dra. Ângela S. Barbosa e Dra. Lourdes Issac. Os oligonucleotídeos utilizados nas clonagens e os números de acesso no GenBank das sequências estão descritos na tabela 1 .

Tabela 1 - Oligonucleotídeos usados nas clonagens e acesso no GenBank.

\begin{tabular}{cll}
$\begin{array}{c}\text { Nomenclatura do } \\
\text { Genoma }\end{array}$ & GenBank & \multicolumn{1}{c}{ oligonucleotideos $^{2}$} \\
\hline LIC10009 & YP_000009 & $\begin{array}{l}\text { F: CGCGCTCGAGAAAAAGGAAGAA } \\
\text { R: AAGCTTTTATTGAAGAATAATTCC }\end{array}$ \\
\hline LIC10301 & YP_000291 & $\begin{array}{l}\text { F: CGGGATCCAAAAAAAAGGAAGAGC } \\
\text { R: GCAAGCTTCTACTCGAGGTTTTCTCGAAATA }\end{array}$ \\
\hline LIC10507 & YP_000491 & $\begin{array}{l}\text { F: CGGGATCCAAAAAGAGTCAAGAAGAATTGG } \\
\text { R: GGTACCCTACTCGAGACAGCCAGGACCTTC }\end{array}$ \\
\hline LIC10704 & YP_000688 & $\begin{array}{l}\text { F: GGATCCATTAAGCCTAGTTCCG } \\
\text { R: GGTACCCTACTCGAGTAAGGA TTTAAC }\end{array}$ \\
\hline LIC11030 & YP_001000 & $\begin{array}{l}\text { F: CCGGGATCCACAAACGAAAAAGAAGG } \\
\text { R: GGTACCCTACTCGAGGTTGCAAGGATTTGG }\end{array}$ \\
\hline LIC11087 & YP_001057 & $\begin{array}{l}\text { F: GGATCCACGTTCGGTTCGGTTG } \\
\text { R: CGCAAGCTTCTACTCGAGAAATAAATTACAAC }\end{array}$ \\
\hline LIC10465 & YP_000449 & $\begin{array}{l}\text { F: CTCGAGCTTACCGTTTCCAACACAAAC } \\
\text { R: CCATGGTTATGGCTCCGTTTTAATAGAG }\end{array}$ \\
\hline
\end{tabular}

${ }^{1}$ LIC: Leptospira interrogans Copenhageni - Fiocruz L1-130; ${ }^{2}$ As clonagem dos genes LIC10009 e LIC10507 em pAE estão descritas em BARBOSA et al., 2006 e GÓMEZ et al., 2008 e as clonagem dos genes LIC10301, LIC10704, LIC11030 e LIC11087 em pAE estão descritas em BARBOSA et al., 2010.

\subsection{Nomenclatura das proteínas}

As lipoproteínas selecionadas, para este trabalho, são hipotéticas e ainda não foram identificadas em nenhum outro organismo e não possuem função conhecida. Dessa forma, foram nomeadas como Lp, do inglês Leptospiral protein, seguido pelo massa molecular calculada da proteína madura (sem peptídeo sinal), conforme descrito na tabela 2 . No caso da proteína codificada pelo gene LIC10465, como a região clonada em pAE corresponde à porção carboxi-terminal, o nome adotado foi LigAc. 
Tabela 2 - Nomenclatura das proteínas

\begin{tabular}{ccc}
\hline $\begin{array}{c}\text { Nomenclatura do } \\
\text { Genoma }^{I}\end{array}$ & $\begin{array}{c}\text { Massa molecular da proteína } \\
\text { nativa madura }\end{array}$ & Nomenclatura \\
\hline LIC10009 & 25,50 & Lp25 \\
\hline LIC10301 & 11,49 & Lp11 \\
\hline LIC10507 & 21,18 & Lp21 \\
\hline LIC10704 & 22,06 & Lp22 \\
\hline LIC11030 & 35,34 & Lp35 \\
\hline LIC11087 & 30,35 & Lp30 \\
\hline LIC10465 & 62,22 & LigAc \\
\hline
\end{tabular}

${ }^{1}$ LIC: Leptospira interrogans Copenhageni Fiocruz L1-130; ${ }^{2}$ Massa molecular calculada utilizando programa disponível em servidor público (http:// www.expasy.ch/) da proteína nativa madura (sem peptídeo sinal).

\subsection{Mini-Preparações de DNA}

Os DNA plasmidiais usados nas transformações, para a expressão das proteínas recombinantes, foram purificados utilizando-se o kit PureLink - Plasmid miniprep (Invitrogen $^{\mathrm{TM}}$, Invitrogen Corporation, Carlsbad, EUA) seguindo as instruções do fabricante. As amostras de DNA plasmidial foram quantificadas por leitura espectrofotométrica a $260 \mathrm{~nm}$ e analisadas em gel de $1 \%$ agarose, 1x TAE (40 mM Tris-acetato, 1 mM EDTA, pH 8,3) e 0,5 $\mu \mathrm{g} / \mu \mathrm{l}$ brometo de etídio.

\subsection{Preparo de células competentes e transformação bacteriana}

As E. coli BL21 (Novagen $^{\circledR}$ ) e BL21(DE3) competentes foram obtidas segundo o protocolo descrito em Sambrook, Fritsch e Maniatis (1989). Uma colônia isolada foi inoculada em $5 \mathrm{~mL}$ de meio líquido $\mathrm{LB}$ e a cultura foi mantida durante a noite, a $37{ }^{\circ} \mathrm{C}$, com agitação de $250 \mathrm{rpm}$. No dia seguinte, $2 \mathrm{~mL}$ da cultura foram inoculados em $100 \mathrm{~mL}$ de meio líquido LB pré-aquecido, mantendo as mesmas condições de crescimento anterior até atingir a densidade ótica a $600 \mathrm{~nm}$ de 0,6 a 0,7. Ao final do período de incubação, a cultura foi resfriada em banho de gelo e $1 \mathrm{~mL}$ de solução $1 \mathrm{M} \mathrm{MgCl}_{2}$ foi adicionado ao cultivo. Após 15 minutos, a cultura foi centrifugada a $1.400 \mathrm{x}$ g por 15 minutos a $4{ }^{\circ} \mathrm{C}$. $\mathrm{O}$ sedimento bacteriano 
foi ressuspendido com $20 \mathrm{~mL}$ de solução RFI (100 mM KCl; $50 \mathrm{mM} \mathrm{MnCl}$; $30 \mathrm{mM}$ Acetato de Potássio; $10 \mathrm{mM} \mathrm{CaCl}_{2}$ e $15 \%$ Glicerol) e mantida em repouso por 15 minutos no gelo. A cultura foi centrifugada a $1.400 \mathrm{x}$ g por 15 minutos a $4{ }^{\circ} \mathrm{C}$ e o sedimento foi ressuspendido em $2 \mathrm{~mL}$ de solução RFII (10 mM KCl; $75 \mathrm{mM} \mathrm{CaCl}_{2} ; 10 \mathrm{mM} \mathrm{Na-MOPS} \mathrm{e} \mathrm{15 \%} \mathrm{Glicerol).} \mathrm{A}$ suspensão foi armazenada a $-80^{\circ} \mathrm{C}$, em alíquotas de $50 \mu$ até o momento do uso.

Para a transformação, as bactérias competentes foram mantidas em banho de gelo por aproximadamente 15 minutos. O DNA plasmidial foi adicionado em cada alíquota de bactéria competente descongelada e o tubo contendo a mistura foi mantido em banho de gelo por 30 minutos. Posteriormente, foi realizado um choque térmico por 2 minutos a $42{ }^{\circ} \mathrm{C}$ e os tubos foram colocados novamente no banho de gelo por 5 minutos. À mistura, foram adicionados $350 \mu 1$ de meio LB previamente aquecido e a incubação foi realizada a $37^{\circ} \mathrm{C}$ com agitação por 90 minutos. A cultura foi plaqueada em meio LB-ágar (1\% bacto-triptona, 0,5\% extrato de levedo, $1 \% \mathrm{NaCl}, 1,5 \%$ bacto-ágar) contendo ampicilina $(100 \mu \mathrm{g} / \mu \mathrm{l})$ e incubada a $37^{\circ} \mathrm{C}$, por 12 a 18 horas.

\subsection{Expressão e purificação das proteínas recombinantes}

Para verificar a expressão das proteínas recombinantes, a estirpe E. coli BL21 (DE3) e E. coli BL21 competentes foram transformadas com as construções em pAE. Colônias isoladas foram inoculadas em $5 \mathrm{~mL}$ de meio LB suplementado com ampicilina (100 $\mu \mathrm{g} / \mu \mathrm{l})$ e incubadas a $37^{\circ} \mathrm{C}$ até se obter DO $600 \mathrm{~nm}=0,6$. Neste momento, retirou-se $1 \mathrm{~mL}$ de cultura bacteriana (controle não induzido) e ao volume restante, adicionou-se $1 \mathrm{mM}$ de IPTG mantendo a incubação por mais 3 horas. As amostras foram centrifugadas por 1 minuto a 15.557x g e os sedimentos, correspondentes a $1 \mathrm{~mL}$ da cultura bacteriana induzida e não induzida, foram ressuspendidos com $100 \mu$ de tampão de aplicação de SDS-PAGE (50 mM Tris pH 6,8; 2\% SDS, 0,1\% Azul bromofenol; 10\% Glicerol e $100 \mathrm{mM} \beta$-mercaptoetanol) As amostras foram fervidas por 3 minutos e aplicadas em gel de 15\% SDS-PAGE. As massas moleculares das proteínas recombinantes foram calculadas a partir da composição de aminoácidos de cada proteína, utilizando a ferramenta Swiss-prot disponível em servidor público (http://expasy.ch/).

Os clones que apresentaram bandas com peso molecular esperado foram selecionados para cultura em maior escala e purificação das proteínas recombinantes. 
Para purificação das proteínas recombinantes, colônias isoladas das transformações com as construções em pAE foram inoculadas em meio LB suplementado com ampicilina $(100 \mu \mathrm{g} / \mathrm{mL})$. A cultura foi incubada a $37{ }^{\circ} \mathrm{C}$ por 18 horas, sob agitação de $250 \mathrm{rpm}$. O préinóculo foi transferido para meio fresco contendo ampicilina, utilizando-se uma diluição 1:20. A cultura foi incubada novamente sob agitação até DO $600 \mathrm{~nm}$ 0,6-0,8. A expressão das proteínas recombinantes foi induzida com a adição de $1 \mathrm{mM}$ de IPTG por mais 3 horas nas mesmas condições anteriores. As células foram coletadas por centrifugação (2.057x g por 15 minutos a $4{ }^{\circ} \mathrm{C}$ ), e o sedimento bacteriano foi armazenado a $-80{ }^{\circ} \mathrm{C}$ até o momento do uso.

Posteriormente, o sedimento bacteriano foi ressuspendido em 5 volumes (p/v) de tampão $20 \mathrm{mM}$ Tris- $\mathrm{HCl}, 0,3 \mathrm{M} \mathrm{NaCl}, 5 \mathrm{mM}$ imidazol e $\mathrm{pH}$ 8,0. A seguir, a suspensão bacteriana foi acrescida de $1 \mathrm{mM}$ PMSF (Phenylmethylsulfonyl Fluoride) e lisada através da passagem pelo French Pressure Cell Press (SLM Aminco).

A suspensão resultante da lise foi centrifugada a 12.857 x g por 15 minutos, a $4{ }^{\circ} \mathrm{C}$. O sobrenadante (fração solúvel) foi coletado e mantido a $4{ }^{\circ} \mathrm{C}$ até o momento da purificação. $\mathrm{O}$ sedimento (corpúsculos de inclusão - fração insolúvel) foi lavado duas vezes com tampão de lavagem (20 mM Tris- $\mathrm{HCl}, 0,5 \mathrm{M} \mathrm{NaCl}, \mathrm{pH}$ 8,0). Amostras da fração solúvel, fração insolúvel e das lavagens foram analisadas em gel SDS-PAGE com 15\% de acrilamida.

As proteínas recombinantes Lp25, Lp21 e Lp22 foram purificadas a partir da fração solúvel, utilizando-se resina de afinidade a metal (Fast Flow Chelating Sepharose ${ }^{\mathrm{TM}}$, GE Healthcare, Uppsala, Suécia) carregada com cinco volumes de $100 \mathrm{mM} \mathrm{NiSO}_{4}$ e equilibrada com três volumes de tampão de ligação (20 mM Tris-HCl; 0,5 M NaCl; $5 \mathrm{mM}$ imidazol, pH 7,9). A seguir, a fração solúvel foi adsorvida à resina com fluxo $0,5 \mathrm{~mL} / \mathrm{min}$. Para eliminação das proteínas contaminantes, a resina foi lavada com 10 volumes do tampão de ligação e 20 volumes do tampão de lavagem (20 mM Tris-HCl; 0,5 M NaCl; 60 mM de imidazol, pH 7,9). As proteínas recombinantes foram eluídas com seis volumes do tampão de eluição $(20 \mathrm{mM}$ Tris-HCl; $0,5 \mathrm{M} \mathrm{NaCl} ; 1 \mathrm{M}$ imidazol, $\mathrm{pH}$ 7,9). As proteínas purificadas foram dialisadas progressivamente contra: (i) $20 \mathrm{mM}$ Tris- $\mathrm{HCl}, 0,5 \mathrm{M} \mathrm{NaCl}, 0,5 \mathrm{M}$ imidazol, $0,1 \%$ glicina e pH 7,9; (ii) 10 mM Tris- $\mathrm{HCl}, 0,5 \mathrm{M} \mathrm{NaCl}, 0,1 \%$ glicina e $\mathrm{pH}$ 7,9; (iii) PBS com 0,1\% glicina e $\mathrm{pH} 7,4$.

As proteínas recombinantes Lp11, Lp30, Lp35 e LigAc foram purificadas a partir da fração insolúvel utilizando cromatografia de afinidade a metal (Fast Flow Chelating Sepharose ${ }^{\mathrm{TM}}$, GE Healthcare). Para tanto, o sedimento de corpúsculos de inclusão foi ressuspendido em 10 volumes (p/v) de tampão de solubilização $(20 \mathrm{mM}$ Tris- $\mathrm{HCl}, 0,5 \mathrm{M}$ 
$\mathrm{NaCl}, 5 \mathrm{mM}$ imidazol, $0,1 \%$ de Triton (v/v), $8 \mathrm{M}$ uréia e $\mathrm{pH}$ 7,9) e mantido a temperatura ambiente por 2 horas com agitação. Posteriormente, o solubilizado foi diluído cem vezes em $20 \mathrm{mM}$ Tris- $\mathrm{HCl}, 0,5 \mathrm{M} \mathrm{NaCl}, 5 \mathrm{mM}$ imidazol e pH 7,9 lentamente. Esta solução foi adsorvida (fluxo $1 \mathrm{~mL} / \mathrm{min}$ ) à coluna de afinidade a metal, previamente carregada com cinco volumes de $100 \mathrm{mM} \mathrm{NiSO}_{4}$ e equilibrada com 3 volumes de tampão de ligação (20 mM Tris$\mathrm{HCl}, 0,5 \mathrm{M} \mathrm{NaCl}, 5 \mathrm{mM}$ imidazol e pH 7,9). Para eliminação das proteínas recombinantes, eluição e diálise, foram utilizados os mesmos procedimentos descritos anteriormente para as proteínas purificadas a partir da fração solúvel.

O acompanhamento das etapas de purificação foi feito utilizando-se método microanalítico com reagente de Bradford (Pierce Protein Research Products, Thermo Fisher Scientific, Rockford, EUA). Para cada $10 \mu \mathrm{l}$ de amostra utilizavam-se $100 \mu \mathrm{l}$ de reagente de Bradford diluído cinco vezes em PBS, numa placa de microdiluição. Como controles eram adicionados $10 \mu \mathrm{l}$ de uma solução contendo albumina numa concentração conhecida e $100 \mu \mathrm{l}$ do tampão em que a amostra se encontrava. Através da leitura da absorbância a $595 \mathrm{~nm}$, a concentração da proteína foi determinada e dessa maneira as amostras foram selecionadas para análises em gel de SDS-PAGE.

Frações de todas as etapas da purificação foram coletadas e analisadas em gel SDSPAGE com $15 \%$ acrilamida.

\subsection{Eletroforese em gel SDS-PAGE}

As eletroforeses foram feitas segundo protocolos descritos por Sambrook, Fritsch e Maniatis (1989). Os géis utilizados possuíam 1,0mm de espessura, 5\% de bisacrilamida/acrilamida no gel de empilhamento e $15 \%$ de bisacrilamida/acrilamida no gel de separação (a partir de uma solução de 29\% Acrilamida e 1\% Bisacrilamida). As eletroforeses foram feitas a $8 \mathrm{~V} / \mathrm{cm}$ de gel de empilhamento e $15 \mathrm{~V} / \mathrm{cm}$ de gel de separação, a temperatura ambiente.

Posteriormente, os géis foram posteriormente corados com "Coomassie Blue Brillant R-250”(USB, Cleveland, OH, EUA) em 50\% metanol e 10\% ácido acético em água por 1-2 horas a temperatura ambiente e descorados com solução de 30\% metanol e $10 \%$ ácido acético em água. Para secar, foram envoltos em papel celofane. 


\subsection{Análise da estrutura secundária e integridade das proteínas recombinantes}

Foram realizados espectros de dicroísmo circular (CD) das proteínas recombinantes utilizando-se o espectropolarímetro modelo J-810 (JASCO), conectado ao sistema Peltier Jasco PFD-425S para controle da temperatura. As amostras de proteínas foram dialisadas na concentração de $10 \mu \mathrm{M}$ contra um tampão contendo $10 \mathrm{mM}$ de sódio-fosfato $\mathrm{pH}$ 7,4. Os dados foram coletados em cubetas de quartzo com $1 \mathrm{~mm}$ de caminho óptico, em uma temperatura de $20{ }^{\circ} \mathrm{C}$, a $0,5 \mathrm{~nm} / \mathrm{seg}$ com um "bandwith" de $1 \mathrm{~nm}$. Cinco espectros foram coletados para se obter uma média de cada medida. A solução de tampão sódio-fosfato pH 7,4 foi usada como branco. Os espectros de CD foram expressos em termos de elipcidade molar, $[\theta]=\theta(\mathrm{mdeg}) / 10 \times \mathrm{C}(\mathrm{M}) \times \mathrm{I}(\mathrm{cm})$, onde $\theta$ é a elipcidade, $\mathbf{C}$ é a concentração da proteína e $\mathbf{I}$ é o caminho óptico.

Com a finalidade de se obter um parâmetro de comparação, empregou-se o programa de predição de estrutura secundária teórica disponível em servidor público, GOR4 (COMBET et al., 2000) disponível no portal ExPASy (http://expasy.org/tools/).

\subsection{Obtenção da flagelina FliCi de Salmonella enterica sorovar Thyphimurium}

A obtenção da flagelina FliCi foi realizada segundo protocolo descrito em Braga et al. (2008) a partir da estirpe de Salmonella enterica sorovar Thyphimurium SL3261, gentilmente cedida pelo Dr. Luis Carlos de Souza Ferreira (Departamento de Microbiologia, ICB-USP). Uma colônia isolada foi inoculada em $50 \mathrm{~mL}$ de meio LB suplementado com $100 \mu \mathrm{g} / \mathrm{mL}$ de canamicina e a cultura foi incubada a $37{ }^{\circ} \mathrm{C}$ com agitação de $80 \mathrm{rpm}$ durante 16 horas. As células foram coletadas por centrifugação a $6.000 \mathrm{x}$ g por 15 minutos, e ressuspensas em $2 \mathrm{~mL}$ de PBS (137 mM NaCl; 2,7 mM KCl; 8,1 mM Na $2 \mathrm{HPO} 4$ e 1,5 mM KH${ }_{2} \mathrm{PO}_{4}$ ). A suspensão bacteriana foi agitada em vórtex em quatro ciclos de 2 minutos com intervalos de 1 minuto no gelo. Posteriormente, para obtenção da fração contendo a flagelina, a suspensão bacteriana foi centrifugada a $8.000 \mathrm{x}$ g por 15 minutos a $4{ }^{\circ} \mathrm{C}$ e o sedimento celular descartado. $\mathrm{O}$ sobrenadante foi coletado e precipitado com quatro volumes de acetona gelada por 16 horas a $-20{ }^{\circ} \mathrm{C}$. O material foi centrifugado a $13.000 \mathrm{x}$ g por 15 minutos a $4{ }^{\circ} \mathrm{C}$ e o precipitado foi ressuspendido em $0,5 \mathrm{~mL}$ de PBS. A fração de flagelina purificada foi submetida a aquecimento a $65^{\circ} \mathrm{C}$ por 30 minutos para promover a despolimerização do filamento flagelar. 


\subsection{Ensaios de imunoproteção em modelo animal}

Os ensaios de imunização e desafio foram realizados no Biotério do Laboratório de Zoonoses Bacterianas coordenado pelo Dr. Sílvio de Arruda Vasconcellos da Faculdade de Medicina Veterinária da Universidade de São Paulo (FMVZ-USP).

Grupos de 10 hamsters (Mesocricetus auratus) machos recém-desmamados, com 4-5 semanas de idade e 80-100 g, foram imunizados subcutaneamente com uma mistura de seis lipoproteínas recombinantes purificadas ( $20 \mu \mathrm{g}$ de cada proteína) na ausência e presença de LigAc recombinante $(50 \mu \mathrm{g})$. As preparações continham $5 \mu \mathrm{g}$ de flagelina e/ou hidróxido de alumínio $\left(5 \mu \mathrm{g}\right.$ de $\mathrm{Al}\left(\mathrm{OH}_{3}\right)$ para cada $1 \mu \mathrm{g}$ de proteína total na mistura), por dose. Como controles negativos, animais foram imunizados com PBS acrescido de flagelina ou hidróxido de alumínio, nas mesmas quantidades usadas nos grupos experimentais. Como controles positivos, animais foram imunizados com $\operatorname{LigAc}(50 \mu \mathrm{g})$, bacterina ou vacina comercial. As preparações contendo LigAc ou bacterina foram acrescidas de flagelina ou hidróxido de alumínio. A vacina comercial utilizada é composta pelas culturas inativadas de seis sorovares de L. interrogans (Bratislava, Canicola, Grippotyphosa, Hardjo, Icterohaemorrhagiae, Pomona), contém hidróxido de alumínio como adjuvante e é para uso em suínos. Como controle do inóculo, um grupo de animais não foi imunizado. Todas as preparações continham PBS como diluente. Foram realizadas duas imunizações com intervalo de 15 dias. A tabela 3 mostra um resumo de todos os grupos utilizados. 
Tabela 3 - Preparação das doses para o ensaio de imunoproteção.

\begin{tabular}{|c|c|}
\hline Grupos & Composição por dose \\
\hline 01- Controle do inóculo ${ }^{\mathrm{a}}$ & - \\
\hline 02- PBS + FliC $i$ & $5 \mu \mathrm{g}$ de Flagelina FliC $i$ \\
\hline $03-\mathrm{PBS}+\mathrm{Al}\left(\mathrm{OH}_{3}\right)$ & $875 \mu \mathrm{g}$ de $\mathrm{Al}\left(\mathrm{OH}_{3}\right)$ \\
\hline 04- Vacina Comercial ${ }^{\mathrm{b}}$ & - \\
\hline 05- Bacterina + FliC $i$ & $10^{8}$ células $+5 \mu \mathrm{g}$ de Flagelina FliC $i$ \\
\hline 06- Bacterina $+\mathrm{Al}\left(\mathrm{OH}_{3}\right)$ & $10^{8}$ células $+875 \mu \mathrm{g}$ de $\mathrm{Al}\left(\mathrm{OH}_{3}\right)$ \\
\hline 07- LigAc+ FliC $i$ & $50 \mu \mathrm{g}$ de LigAc $+5 \mu \mathrm{g}$ de Flagelina FliC $i$ \\
\hline $08-\mathrm{LigAc}+\mathrm{Al}\left(\mathrm{OH}_{3}\right)$ & $50 \mu \mathrm{g}$ de $\mathrm{LigAc}+250 \mu \mathrm{g}$ de $\mathrm{Al}\left(\mathrm{OH}_{3}\right)$ \\
\hline 09- Pool + FliC $i$ & $20 \mu \mathrm{g}$ de cada lipoproteína $+5 \mu \mathrm{g}$ de Flagelina FliC $i$ \\
\hline $10-\mathrm{Pool}+\mathrm{Al}\left(\mathrm{OH}_{3}\right)$ & $20 \mu \mathrm{g}$ de cada lipoproteína $+600 \mu \mathrm{g}$ de $\mathrm{Al}\left(\mathrm{OH}_{3}\right)$ \\
\hline 11- Pool + LigAc + FliCi & $\begin{array}{l}20 \mu \mathrm{g} \text { de cada lipoproteína }+50 \mu \mathrm{g} \text { de } \operatorname{LigAc}+5 \mu \mathrm{g} \text { de } \\
\text { Flagelina FliC } i\end{array}$ \\
\hline 12- Pool $+\operatorname{LigAc}+\mathrm{Al}\left(\mathrm{OH}_{3}\right)$ & $\begin{array}{l}20 \mu \mathrm{g} \text { de cada lipoproteína }+50 \mu \mathrm{g} \text { de LigAc }+850 \mu \mathrm{g} \text { de } \\
\mathrm{Al}\left(\mathrm{OH}_{3}\right)\end{array}$ \\
\hline
\end{tabular}

a - Grupo não imunizado; b - Vacina comercial: informações não disponíveis.

A preparação da bacterina foi realizada segundo protocolo descrito por Silva et al. (2007). Para tanto, a estirpe L. interrogans sorovar Copenhageni (Fiocruz L1-130) foi cultivada em meio EMJH modificado a $29^{\circ} \mathrm{C}$ sem agitação, por sete dias. Posteriormente, a cultura foi centrifugada, por 30 minutos, a 11.000x g e o sedimento bacteriano foi lavado duas vezes com PBS. O sedimento bacteriano lavado foi ressuspendido em PBS e inativado, por 20 minutos, a $56{ }^{\circ} \mathrm{C}$ e estocado a $-20{ }^{\circ} \mathrm{C}$ até o momento do uso. Os hamsters foram imunizados com a dose de $10^{8}$ leptospiras inativadas em $200 \mu 1$.

Os animais imunizados foram desafiados intraperitonialmente, quinze dias após a última imunização, com $200 \mu \mathrm{l}\left(2 \times 10^{5}\right.$ células $)$ de uma cultura de L. interrogans sorovar Copenhageni estirpe Fiocruz L1-130 virulenta. Os hamsters foram monitorados diariamente para acompanhamento de sinais clínicos de leptospirose, como hemorragia externa, desidratação, anorexia e diminuição da atividade. Os animais que sobreviveram após o $21^{\circ}$ dia do desafio foram sacrificados e necropsiados, os rins foram coletados para a avaliação do estado de portador renal, através da detecção de Leptospira em meio semi-sólido e análises histológicas. Para tanto, um dos rins, de cada animal sobrevivente foi macerado assepticamente em $1 \mathrm{~mL}$ de solução tamponada de Sörensen. A suspensão resultante foi 
diluída 100x e 1000x em solução tamponada de Sörensen. Cem microlitros de cada diluição foram semeados em $5 \mathrm{~mL}$ de meio semi-sólido de Fletcher, dois tubos por diluição e mantidos a $29{ }^{\circ} \mathrm{C}$, por 42 dias, com observações semanais para a formação do anel de crescimento sub-superficial de leptospiras no meio (Figura 13). O outro rim coletado foi imediatamente fixado em solução de formalina tamponada a $10 \%$ e posteriormente desidratado em soluções contendo etanol (70\% e $90 \%)$ e etanol absoluto e por último, em xilol absoluto, cada um por duas lavagens. O material foi colocado em parafina aquecida a 60 ${ }^{\circ} \mathrm{C}$ por duas horas e emoldurado em blocos. Os blocos foram cortados em micrótomo numa espessura de aproximadamente $5 \mu \mathrm{m}$ e processados para exame histológico, através da coloração pela prata pelo método de Warthin-Starry. Nesta coloração, as leptospiras se coram de marrom escuro ou negro e o fundo adquire uma cor amarelada. A observação das lâminas foi realizada em microscópio ótico com imersão à óleo (aumento de 100x).

A determinação da DL50 (ANEXO A) foi feita paralelamente ao experimento de desafio, pois a cultura de leptospiras perde a virulência com passagens de crescimento. Para tanto, foram utilizados hamsters do mesmo grupo dos animais do desafio, portanto da mesma idade e sexo, machos entre 8 e 9 semanas. Uma cultura de L. interrogans sorovar Copenhageni estirpe Fiocruz L1-130 virulenta, na primeira passagem, foi diluída em PBS (10 ${ }^{1}$ a $10^{6}$ células/dose) e injetada em 5 animais para cada diluição. Um grupo controle foi injetado somente com PBS. Foi utilizada via intraperitonial com volume de $200 \mu$ l. Os animais foram monitorados por 21 dias e a $\mathrm{DL}_{50}$ foi calculada através do método de Reed-Muench (1938).

Para o acompanhamento do título de anticorpos, através de ELISA e análise da expressão dos genes de citocinas de resposta Th1/Th2 em células mononucleares do sangue periférico por RT-qPCR, os animais imunizados foram sangrados, via plexo retro-orbital, antes das imunizações (pré-imune) e após as imunizações: um dia antes da segunda imunização (ELISA), dois dias depois da segunda imunização (RT-qPCR) e um dia antes do desafio (RT-qPCR e ELISA). O sangue coletado foi mantido a $37^{\circ} \mathrm{C}$, por 30 minutos e a $4{ }^{\circ} \mathrm{C}$, por 60 minutos, posteriormente, o coágulo foi deslocado da parede do tubo e centrifugado a 800x g, por 15 minutos. Após a centrifugação o sobrenadante coletado foi armazenado a -20 ${ }^{\circ} \mathrm{C}$.

O esquema dos ensaios de imunização e desafios realizados está representado na figura 2 . 


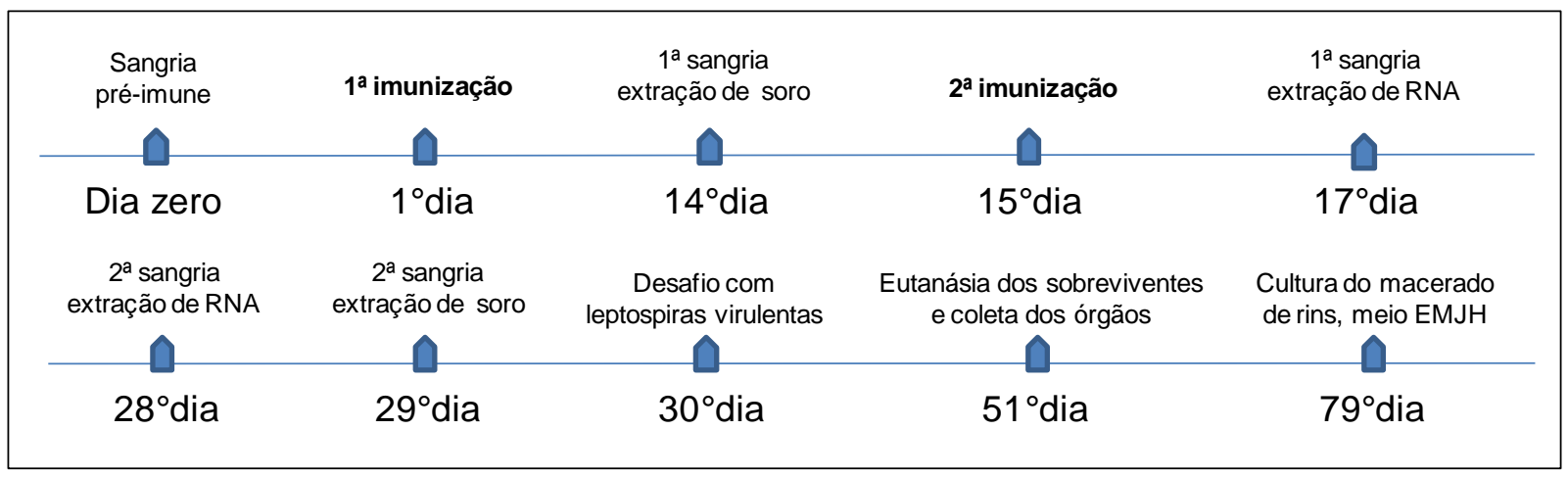

Figura 2: Representação esquemática do plano de ensaio de imunoproteção em hamsters.

\subsection{ELISA}

A titulação dos soros foi feita por ELISA (enzyme-linked immunosorbent assay). Para a adsorção dos antígenos, placas de micro-diluição de 96 poços de poliestireno de alta afinidade (Corning Brasil, São Paulo, Brasil) foram expostas a uma solução de $5 \mu \mathrm{g} / \mathrm{mL}$ de cada proteína recombinante purificada ou $10 \mu \mathrm{g} / \mathrm{mL}$ de bacterina em tampão $0,1 \mathrm{M}$ carbonato/bicarbonato $\mathrm{pH}$ 9,6 e incubadas, por 16 horas, a $4{ }^{\circ} \mathrm{C}$. Os sítios inespecíficos foram bloqueados incubando-se a placa com solução de bloqueio (10\% leite desnatado liofilizado em PBS com 0,05\% Tween-20), por 1 hora, a $37^{\circ} \mathrm{C}$. Posteriormente, a placa foi lavada, mais uma vez, com PBS-T (PBS com 0,05\% Tween-20) para retirar o excesso de solução de bloqueio.

Após as lavagens, foram realizadas diluições seriadas dos soros dos animais em tampão de diluição (1\% leite desnatado liofilizado em PBS com 0,01\% Tween-20). A placa foi incubada, por 16 horas, a $4{ }^{\circ} \mathrm{C}$. Posteriormente, os poços foram lavados três vezes com PBS-T e a reação com o segundo anticorpo anti-hamster, produzido em coelho (Sigma) diluído 1:5000 em tampão de diluição, foi realizada, por 1 hora, a $37^{\circ} \mathrm{C}$. Em seguida, a placa foi lavada três vezes com PBS-T. O terceiro anticorpo, anti-coelho conjugado com peroxidase (Sigma) foi então, adicionado na diluição 1:5000 em tampão de diluição e a placa foi incubada, por 1 hora, a $37^{\circ} \mathrm{C}$, seguido de lavagens como descrito anteriormente.

O reconhecimento foi realizado através de reação, com o substrato ortofenilenodiamina (OPD), em tampão citrato-fosfato na presença de traços de $\mathrm{H}_{2} \mathrm{O}_{2}$, por 10

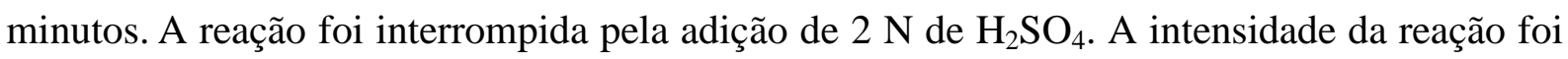
determinada pela leitura da DO em 492 nm (Multiskan EX, Thermo Fisher Scientific, Rockford, EUA). 
O título de anticorpos foi considerado como a maior diluição do soro capaz de resultar em uma leitura de absorbância a $492 \mathrm{~nm}$ superior a 0,1 .

A preparação da bacterina, utilizada na adsorção das placas, foi realizada segundo protocolo descrito anteriormente com meio EMJH completo, para evitar a reação entre o soro de coelho presente no meio EMJH modificado, com o anticorpo anti-coelho conjugado com peroxidase (Sigma-Aldrich, St. Louis, EUA) utilizado no ELISA.

\subsection{Western-Blotting}

Os títulos dos soros obtidos foram utilizados como referência na diluição dos mesmos nos experimentos de Western-Blotting. As proteínas recombinantes purificadas foram submetidas à eletroforese em gel SDS-PAGE (15\%) e transferidas por sistema úmido (BioRad Laboratories, Hercules, EUA) para uma membrana de nitrocelulose (Hybond-ECL - GE Healthcare), durante uma hora a $0,65 \mathrm{~mA} / \mathrm{cm}$ de gel, imersos em tampão de transferência (48 mM Tris-Base, 39 mM Glicina, 20\% etanol e 0,037\% SDS, pH 8,3). Após a transferência, a membrana foi corada com Ponceau S (0,1\% Ponceau em 10\% ácido acético), O excesso de corante foi lavado com água destilada e digitalizada para monitorização da transferência. $\mathrm{O}$ gel foi corado com 0,25\% de Coomassie Blue Brillant em 50\% etanol e $10 \%$ ácido acético em água, por 1-2 horas, a temperatura ambiente e descorado com solução de $30 \%$ etanol e $10 \%$ ácido acético em água para controle da transferência (BURNETTE, 1981).

Os sítios inespecíficos foram bloqueados incubando-se a membrana com solução de bloqueio (10\% leite desnatado liofilizado em PBS com 0,2\% Tween-20) sob agitação, por 16 horas, a $4{ }^{\circ} \mathrm{C}$. Posteriormente, a membrana foi lavada três vezes com PBS-T (PBS com 0,2\% Tween-20) sob agitação por 15 minutos .

A reação com o primeiro anticorpo foi feita com soro dos animais imunizados diluído 1:1000, seguido de incubação com o segundo anticorpo anti-hamster, produzido em coelho (Sigma) diluído 1:5000 e por último, com terceiro anticorpo, anti-coelho conjugado com peroxidase (Sigma) na diluição 1:5000. Os soros e anticorpos foram diluídos em PBS-T e as incubações foram realizadas por 1 hora a temperatura ambiente com agitação. Depois de cada incubação, a membrana foi lavada três vezes com PBS-T, por 15 minutos, à temperatura ambiente com agitação. A detecção foi realizada através da utilização de "kit" ECL (GE Healthcare). A membrana foi exposta a filme de raios-X (Hyperfilm - GE Healthcare) por tempos curtos (30 segundos a 2 minutos), o filme foi revelado e digitalizado. 


\subsection{Soroaglutinação Microscópica (SAM)}

O teste de soroaglutinação microscópica foi realizado utilizando-se como antígeno uma cultura de L. interrogans sorovar Copenhageni estirpe L1-130 (1x10 ${ }^{8}$ células $\left./ \mathrm{mL}\right)$. Os soros foram diluídos 1:50 em solução tamponada de Sörensen e em placa de microdiluição foram adicionados $50 \mu \mathrm{l}$ desta diluição e o mesmo volume da cultura de L. interrogans, resultando numa diluição final de 1:100. A placa foi levemente agitada e incubada a $28{ }^{\circ} \mathrm{C}$ por 1 hora e em seguida foi realizada a leitura em microscópio de campo escuro (Carl Zeiss7). Foi avaliado o grau de aglutinação, sendo 1+ cerca de $25 \%$ das leptospiras aglutinadas presentes no campo microscópico, 2+ quando cerca de 50\%, 3+ quando $75 \%$ e $4+$ acima de $75 \%$. Posteriormente, os soros foram titulados em uma série de diluições geométricas de razão dois, sendo a diluição inicial 1/50, utilizando como antígenos 22 sorovares de espécies patogênicas (Australis, Bratislava, Autumnalis, Butembo, Castellonis, Bataviae, Canicola, Whitcombi, Cynopteri, Grippotyphosa, Hebdomadis, Copenhageni, Icterohaemorrhagiae, Javanica, Panama, Pomona, Pyrogenes, Hardjo, Wolffi, Shermani, Tarassovi, Sentot) e dois sorovares de leptospiras não patogênicas (Andamana e Patoc.). O título foi considerado a maior diluição que apresentou 50\% de leptospiras aglutinadas (SOTO, 2006; RODRIGUES, 2008).

\subsection{Teste de inibição de crescimento de Leptospiras}

A avaliação da presença de anticorpos neutralizantes foi realizada através do teste de inibição de crescimento bacteriano in vitro. Para tanto, foram selecionados os soros da segunda sangria, previamente inativados a $56{ }^{\circ} \mathrm{C}$ durante 30 minutos. Numa placa de cultura de 96 poços (Corning, Costar 3799) os soros foram diluídos na proporção de 1:2; 1:4; 1:8 e 1:16 em PBS, num volume final de $50 \mu \mathrm{l}$ e a cada poço foram adicionados $50 \mu \mathrm{l}$ de uma

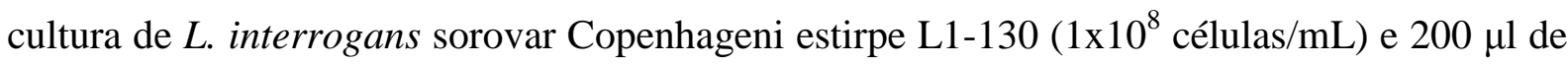
meio EMJH. As placas foram mantidas a $29{ }^{\circ} \mathrm{C}$ por sete dias. Após este período, $100 \mu \mathrm{l}$ de cada poço foram adsorvidos em placas de micro-diluição de 96 poços de poliestireno de alta afinidade (Corning) por 16 horas a $4{ }^{\circ} \mathrm{C}$. A quantificação da presença de leptospiras foi realizada por ELISA (conforme descrito no item 3.12), utilizando o soro de referência antiL.interrogans Sorovar Copenhageni estirpe 10 A, produzido em coelho e anti-coelho conjugado com peroxidase (Sigma), ambos na diluição 1:10.000. 
Para confirmar o teste de inibição do crescimento feito em placa, paralelamente foi realizado o teste de inibição do crescimento em tubo. Para cada soro, foram adicionados 2,5 $\mathrm{mL}$ de meio EMJH, $100 \mu \mathrm{l}$ de uma cultura de L. interrogans sorovar Copenhageni ( $1 \times 10^{8}$ células/mL) e $100 \mu \mathrm{l}$ de soro em tubos de vidro mantidos a $29{ }^{\circ} \mathrm{C}$ por sete dias. Foram considerados positivos para anticorpos neutralizantes aqueles tubos sem crescimento de leptospiras, observando a turbidez, seguido de análise em microscópio de campo escuro (SOTO, 2006; RODRIGUES, 2008).

\subsection{Extração de RNA total}

Os animais imunizados foram sangrados via plexo retro-orbital na presença de EDTA como anticoagulante. Foram coletados $3 \mathrm{~mL}$ de sangue total de cada grupo de 10 hamsters. O RNA total foi extraído, imediatamente após a coleta do sangue, utilizando-se o kit QiAamp RNA Blood Mini (Qiagen,Valencia, EUA), segundo as instruções do fabricante. Neste método, os eritrócitos são seletivamente lisados e os leucócitos recuperados por centrifugação. Posteriormente, o sedimento celular de leucócitos é, então, lisado em condições desnaturantes que permitem a inativação das RNases. Na etapa seguinte, etanol é adicionado ao lisado de leucócitos e a amostra é aplicada numa minicoluna de sílica gel. O RNA liga-se à sílica e os contaminantes podem ser eliminados com lavagens da coluna e o RNA total é eluído com água livre de RNAses. O RNA obtido foi mantido a $-80{ }^{\circ} \mathrm{C}$ até o momento do uso e quantificado por leitura espectrofotométrica a $260 \mathrm{~nm}$. O grau de pureza foi determinado pela relação $\mathrm{A}_{260 \mathrm{~nm}} / \mathrm{A}_{280 \mathrm{~nm}}$ e a integridade do RNA foi avaliada por eletroforese em gel de $1 \%$ agarose em tampão TBE (0,445 M Tris; 0,445 M Ácido Bórico; 0,01 M EDTA e pH 8,3) corado com $0,5 \mu \mathrm{g} / \mu \mathrm{l}$ de brometo de etídio.

As amostras de RNA foram tratadas com deoxirribonuclease I livre de RNase (DNase I - Invitrogen ${ }^{\mathrm{TM}}$ ) com 5 unidades da enzima para cada $1 \mu \mathrm{g}$ de RNA em tampão fornecido pelo fabricante durante 15 minutos a $37^{\circ} \mathrm{C}$. 


\subsection{Preparação do DNA complementar}

A transcrição reversa foi realizada usando o kit SuperScript ${ }^{T M}$ First-Strand Synthesis System for RT-PCR (Invitrogen ${ }^{\mathrm{TM}}$ ) e $1 \mu \mathrm{g}$ de RNA tratado com Dnase I. O RNA foi incubado com $10 \mathrm{mM}$ de DNTPs e $0,5 \mu \mathrm{g} / \mathrm{mL}$ de oligo $(\mathrm{dT})_{12-18}$ por 5 minutos a $65^{\circ} \mathrm{C}$. Posteriormente, a amostra foi transferida para o gelo e foram adicionados $2 \mu$ do tampão da enzima ( $200 \mathrm{mM}$ Tris- $\mathrm{HCl}, 500 \mathrm{mM} \mathrm{KCl}, 25 \mathrm{mM} \mathrm{MgCl} 2,0,1 \mathrm{M}$ DTT) e 40 unidades de inibidor de RNase. Os tubos foram mantidos a $42{ }^{\circ} \mathrm{C}$ por 2 minutos e em seguida 50 unidades da transcriptase reversa SuperScript II RT foram adicionadas a cada reação e incubou-se a $50{ }^{\circ} \mathrm{C}$ por 50 minutos, $85{ }^{\circ} \mathrm{C}$ por 5 minutos, $4{ }^{\circ} \mathrm{C}$ por 1 minuto e em seguida foram adicionadas 2 unidades de RNase $\mathrm{H}$ e a reação foi mantida por mais 20 minutos a $37{ }^{\circ} \mathrm{C}$. As amostras foram armazenadas a $-20^{\circ} \mathrm{C}$.

\subsection{Reação em cadeia pela polimerase (PCR) e densitometria}

As reações de PCR foram realizadas em um volume final de $20 \mu \mathrm{l}$, contendo 1/10 (dos $20 \mu \mathrm{l})$ de cDNA; $2 \mathrm{mM} \mathrm{MgCl} 2 ; 0,2 \mu \mathrm{M}$ de cada Oligonucleotídeo; $200 \mu \mathrm{M}$ de dNTPs e $2 \mathrm{U}$ de Taq polimerase Platinum (Invitrogen ${ }^{\mathrm{TM}}$ ) em tampão fornecido pelo fabricante. As condições de amplificação e as sequências dos oligonucleotídeos utilizados estão descritas na tabela 4. Os produtos da amplificação foram analisados em gel de agarose $1 \%$ em solução TAE, corado com $0,5 \mu \mathrm{g} / \mu \mathrm{l}$ de brometo de etídio.

Posteriormente, os géis foram visualizados e analisados em um transiluminador de luz ultravioleta e as imagens foram capturadas e digitalizadas no sistema de imagens AlphaEaseFC (Alpha Imager 2200). As imagens foram impressas na melhor qualidade no formato negativo e analisadas no densitômetro GS-800 (BioRad) acoplado ao programa Quantity One.

O cálculo do valor da expressão relativa de cada amostra foi obtido pela densidade óptica (em pixéis) de cada banda. Os valores foram obtidos dividindo-se o valor da densidade óptica dos produtos de amplificação dos genes de interesse (INF $\gamma$, IL4, IL10 e IL12p40) pelo valor da densidade óptica do produto de amplificação do controle endógeno, neste caso foi utilizado o gene da proteína de citoesqueleto $\beta$-actina, por ser expressa constitutiva e abundantemente expressa em células de mamíferos. Portanto, expressão relativa = gene de interesse / controle endógeno. Os valores obtidos foram expressos em unidades arbitrárias. 
Tabela 4 - Oligonucleotídeos utilizados para detecção da expressão de citocinas.

\begin{tabular}{|c|c|c|c|c|c|c|}
\hline \multirow{2}{*}{ Gene } & \multirow{2}{*}{ Primer } & \multirow{2}{*}{ Sequência } & \multicolumn{4}{|c|}{ Condições de PCR } \\
\hline & & & Ciclos $_{1}$ & $\operatorname{Desn}_{2}$ & $\mathrm{Anel}_{3}$ & $\boldsymbol{E x t}_{4}$ \\
\hline \multirow{2}{*}{ IFN- $\gamma$} & $\mathrm{F}$ & GACAACCAGGCCATCC & \multirow{2}{*}{35} & \multirow{2}{*}{$\begin{array}{c}94^{\circ} \mathrm{C} \\
15 \mathrm{seg}\end{array}$} & \multirow{2}{*}{$\begin{array}{c}55^{\circ} \mathrm{C} \\
30 \mathrm{seg}\end{array}$} & \multirow{2}{*}{$\begin{array}{c}72^{\circ} \mathrm{C} \\
60 \mathrm{seg}\end{array}$} \\
\hline & $\mathrm{R}$ & CAAAACAGCACCGACT & & & & \\
\hline \multirow{2}{*}{ IL 4} & $\mathrm{~F}$ & CTCCTATCACTGACGGT & \multirow{2}{*}{40} & \multirow{2}{*}{$\begin{array}{c}94^{\circ} \mathrm{C} \\
30 \mathrm{seg}\end{array}$} & \multirow{2}{*}{$\begin{array}{c}50^{\circ} \mathrm{C} \\
30 \mathrm{seg}\end{array}$} & \multirow{2}{*}{$\begin{array}{c}72^{\circ} \mathrm{C} \\
60 \mathrm{seg}\end{array}$} \\
\hline & $\mathrm{R}$ & ATTCACATTGCAGCTCT & & & & \\
\hline \multirow{2}{*}{ IL-10 } & $\mathrm{F}$ & TGGACAACATACTACTCACTG & \multirow{2}{*}{35} & \multirow{2}{*}{$\begin{array}{c}94^{\circ} \mathrm{C} \\
15 \mathrm{seg}\end{array}$} & \multirow{2}{*}{$\begin{array}{c}55^{\circ} \mathrm{C} \\
30 \mathrm{seg}\end{array}$} & \multirow{2}{*}{$\begin{array}{c}72^{\circ} \mathrm{C} \\
60 \mathrm{seg}\end{array}$} \\
\hline & $\mathrm{R}$ & GATGTCAAATTCATTCATGGC & & & & \\
\hline \multirow{2}{*}{ IL-12p40 } & $\mathrm{F}$ & AGATCCTAAAAATAAGACCTT & \multirow{2}{*}{40} & \multirow{2}{*}{$\begin{array}{c}94^{\circ} \mathrm{C} \\
30 \mathrm{seg}\end{array}$} & \multirow{2}{*}{$\begin{array}{c}50^{\circ} \mathrm{C} \\
30 \mathrm{seg}\end{array}$} & \multirow{2}{*}{$\begin{array}{c}72^{\circ} \mathrm{C} \\
60 \mathrm{seg}\end{array}$} \\
\hline & $\mathrm{R}$ & AGTTCTCGTATTTATACTTGT & & & & \\
\hline \multirow{2}{*}{$\beta$-actina } & $\mathrm{F}$ & TCTACAACGAGCTGCG & \multirow{2}{*}{35} & \multirow{2}{*}{$\begin{array}{c}94^{\circ} \mathrm{C} \\
15 \mathrm{seg}\end{array}$} & \multirow{2}{*}{$\begin{array}{c}55^{\circ} \mathrm{C} \\
30 \mathrm{seg}\end{array}$} & \multirow{2}{*}{$\begin{array}{c}72^{\circ} \mathrm{C} \\
60 \mathrm{seg}\end{array}$} \\
\hline & $\mathrm{R}$ & CAATTTCCCTCTCGGC & & & & \\
\hline
\end{tabular}

$\mathrm{F}=$ Foward $\mathrm{R}=$ Reverse. Todas as amostras foram desnaturadas inicialmente a $94^{\circ} \mathrm{C}$ por 2 minutos; 1 número de ciclos; 2 - Desnaturação; 3 - Anelamento; 4 - Extensão.

\subsection{Reação em cadeia pela polimerase em Tempo Real (RT-qPCR)}

O PCR em tempo real possibilita quantificar ácidos nucléicos com maior precisão e reprodutibilidade, pois nesta técnica se determina os valores durante a fase exponencial da reação. O ponto que permite a quantificação, baseado na fluorescência, que atinge o limiar da fase exponencial é chamado de $\mathrm{C}_{\mathrm{t}}$ (Cycle Threshold). A amplificação tem três fases: linha basal, que não há produto suficiente para detecção; fase $\log$, quando os produtos de PCR dobram a cada ciclo e a fase platô, quando não há aumento de produto. A emissão de fluorescência aumenta em relação a quantidade de produto de PCR, um dos fluoróforos usados é SYBR ${ }^{\circledR}$ Green, molécula que se liga entre a fita do DNA e é excitado pela luz emitida pelo termociclador (NOVAIS, 2004).

A análise da expressão dos genes de citocinas INF $\gamma$, IL-12p40 (resposta Th1), IL-4 e IL-10 (resposta Th2) em células mononucleares do sangue periférico foi realizada por PCR em Tempo Real (RT-qPCR). O número de cópias dos genes foi determinado utilizando-se o “kit" Platinum ${ }^{\circledR} S Y B R^{\circledR}$ Green qPCR SuperMix UDG (Invitrogen ${ }^{\mathrm{TM}}$ ). O volume total da reação foi de $25 \mu 1$, composto por $2 \mu 1$ do cDNA, obtido da transcrição reversa, 12,5 $\mu 1$ de Platinum $^{\circledR}$ SYBR ${ }^{\circledR}$ Green qPCR SuperMix UDG , $2 \mu \mathrm{l}$ de cada Oligonucleotídeo $(10 \mu \mathrm{M})$, descritos na tabela 4 e completa-se o volume com água. 
A análise das citocinas e os dados foram obtidos através do instrumento MJ Research PTC 200 (Peltier Thermal Cycler) e do software Opticon Monitor 2 (Analisy Software). O protocolo de amplificação constitui-se de uma incubação a $50{ }^{\circ} \mathrm{C}$ por 2 minutos, ativação da enzima a $95{ }^{\circ} \mathrm{C}$ por 5 minutos, seguido de 40 ciclos com desnaturação a $95{ }^{\circ} \mathrm{C}$ por 20 segundos, anelamento a $60{ }^{\circ} \mathrm{C}$ por 35 segundos e extensão de $55^{\circ} \mathrm{C}$ a $90{ }^{\circ} \mathrm{C}$, onde a cada um grau é adquirida a fluorescência. Para analisar os dados obtidos do estudo da expressão de citocinas foi utilizado o métodos $2^{-\Delta \Delta C_{\mathrm{T}}}$ descrito por Livak (2001), este método é conveniente para analisar a expressão gênica relativa por PCR quantitativo em tempo real. 


\section{RESULTADOS}

\subsection{Purificação e caracterização de proteínas recombinantes}

A primeira etapa deste trabalho foi a expressão das proteínas recombinantes e o estabelecimento de um protocolo de purificação adequado para cada proteína. Na figura 3 está esquematizado um fluxograma geral do processo.

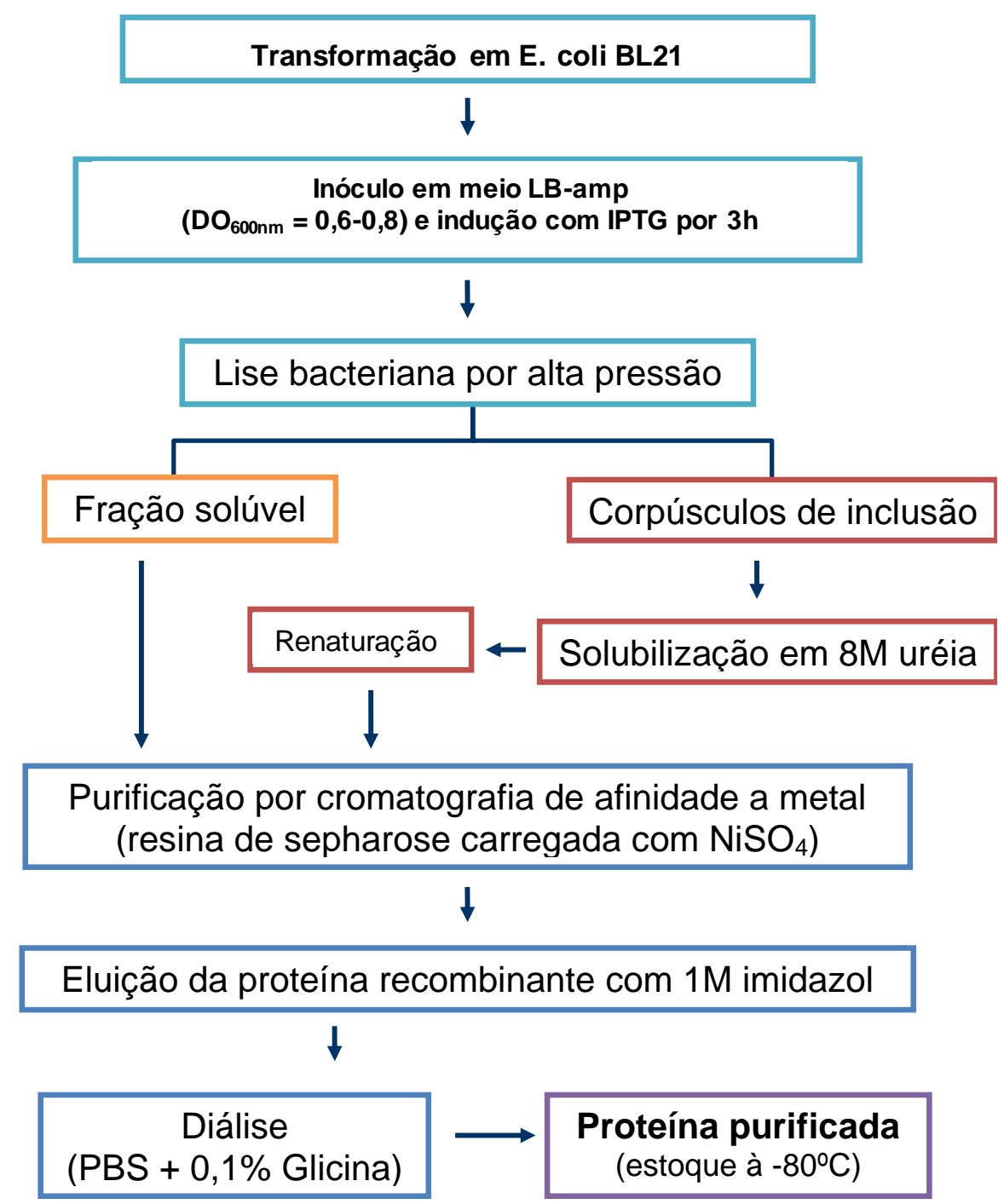

Figura 3: Fluxograma do processo de expressão e purificação de proteínas recombinantes. 
Para expressar as proteínas recombinantes, as estirpes E. coli BL21-C43 ou BL21 competentes foram transformadas com os plasmídeos pAE-LIC10009 (Lp25), pAE-LIC10301 (Lp11), pAE-LIC10507 (Lp21), pAE-LIC10704 (Lp22), pAE-LIC11030 (Lp35), pAELIC11087 (Lp30) e pAE-10465 (LigAc). Colônias isoladas, obtidas destas transformações, foram inoculadas em meio líquido LB-amp, a cultura foi mantida a $37^{\circ} \mathrm{C}$ sob agitação até DO $600 \mathrm{~nm}=0,6$. Neste momento, adicionou-se $1 \mathrm{mM}$ de IPTG, mantendo-se a incubação por mais 3 horas. Após a indução, a cultura bacteriana foi centrifugada e o sedimento foi utilizado para purificação das proteínas recombinantes.

As proteínas recombinantes Lp25, Lp21, Lp22 foram purificadas a partir da fração solúvel adsorvida à resina de afinidade a metal. Proteínas contaminantes foram eliminadas pela passagem de solução de lavagem contendo concentrações crescentes de imidazol (20 mM a $100 \mathrm{mM}$ ). Após a eluição com $1 \mathrm{M}$ imidazol, as proteínas purificadas foram dialisadas contra tampão PBS e $0,1 \%$ glicina.

As proteínas recombinantes Lp11, Lp30, Lp35 e LigAc foram purificadas a partir da fração insolúvel, o sedimento de corpúsculos de inclusão foi ressuspendido em tampão de solubilização contendo $8 \mathrm{M}$ uréia, como agente desnaturante e posteriormente, o solubilizado foi diluído 100 vezes lentamente em tampão de renaturação, com o objetivo de diminuir a quantidade de uréia (de $8 \mathrm{M}$ até zero) e recuperar a conformação estrutural da proteína. Esta solução foi adsorvida à coluna de afinidade a metal para eliminação das proteínas contaminantes, eluição das proteínas recombinantes e diálise foram utilizados os mesmos procedimentos descritos para as proteínas solúveis.

A figura 4 mostra o resultado da purificação das proteínas recombinantes após a diálise. É possível verificar que a maioria das proteínas contaminantes foram eliminadas com o processo de purificação e todas as proteínas recombinantes são bandas majoritárias.

O ponto isoelétrico e a massa molecular de cada proteína foram calculados a partir da composição de aminoácidos, utilizando a ferramenta Swiss-prot disponível em servidor público (http://expasy.ch/). O pI, a massa molecular, o número de aminoácidos, a estimativa do rendimento da purificação e a concentração de imidazol na última lavagem para cada proteína recombinante estão descritos na tabela 5 . 

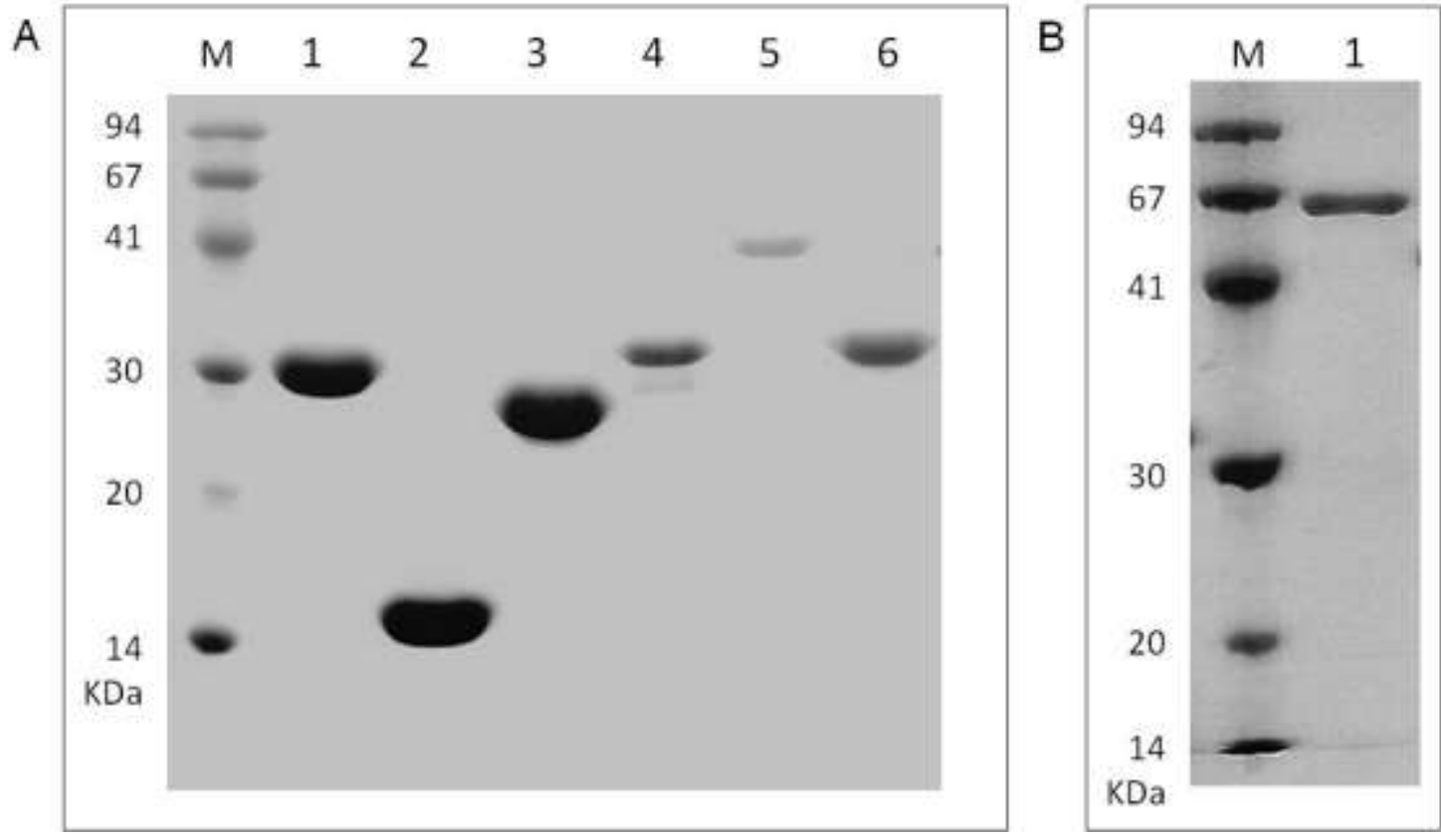

Figura 4: Análise da purificação das proteínas recombinantes. Gel SDS-PAGE (15\%). A) M Marcador de peso molecular LMW (BioRad); 1 - Lp25; 2 - Lp11; 3 - Lp21; 4 - Lp22; 5 - Lp35; 6 - Lp30; B) M - Marcador de peso molecular; 1 - LigAc.

Tabela 5 - Dados da purificação das proteínas recombinantes.

\begin{tabular}{|c|c|c|c|c|c|c|c|}
\hline $\begin{array}{c}\text { Proteína } \\
\text { Recombinante }\end{array}$ & $\begin{array}{c}\text { Massa } \\
\text { Molecular } \\
(\text { kDa })\end{array}$ & $\begin{array}{l}\text { Número de } \\
\text { aminoácidos }\end{array}$ & $p I^{a}$ & $\begin{array}{c}\text { E. coli } \\
\text { usada na } \\
\text { expressãa }\end{array}$ & $\begin{array}{c}\text { Fração } \\
\text { utilizada na } \\
\text { purificação }\end{array}$ & $\begin{array}{c}\text { Concentração } \\
\text { de } \text { imidazol }^{b} \\
(m M)\end{array}$ & $\begin{array}{c}\text { Rendimento } \\
(\mathrm{mg} / \mathrm{L})\end{array}$ \\
\hline Lp25 & 26,47 & 233 & 6.12 & BL21(C43) & Solúvel & 60 & 29 \\
\hline Lp11 & 12,98 & 108 & 6.30 & BL21(DE3) & Insolúvel & 100 & 18 \\
\hline Lp21 & 22,66 & 199 & 5.53 & BL21(C43) & Solúvel & 60 & 37 \\
\hline Lp22 & 23,54 & 210 & 5.43 & BL21(DE3) & Solúvel & 60 & 5,5 \\
\hline Lp35 & 36,83 & 339 & 6.17 & BL21(DE3) & Insolúvel & 60 & 7,5 \\
\hline Lp30 & 31,83 & 284 & 5.65 & BL21(DE3) & Insolúvel & 100 & 10 \\
\hline LigAc & 63,43 & 603 & 7.82 & BL21(C43) & Insolúvel & 100 & 38 \\
\hline
\end{tabular}

\footnotetext{
${ }^{\mathrm{a}}$ pI: ponto isoelétrico; ${ }^{\mathrm{b}}$ Concentração de imidazol utilizada na última lavagem.
} 


\subsection{Dicroísmo Circular}

O dicroísmo circular (CD) é particularmente útil para o estudo de moléculas como proteínas que possuem unidades opticamente ativas, ou seja, que podem exibir sinal na espectroscopia de dicroísmo circular. Quando tais moléculas interagem com a luz circularmente polarizada provocam uma alteração nessa luz incidente. A técnica de CD detecta a alteração através da medida da diferença da absorção da luz circularmente polarizada à esquerda e à direita, após a luz passar pela amostra. O CD pode ser utilizado para detectar mudanças conformacionais. Esta técnica apresenta vantagens como recuperação da amostra e análise feita em solução, que reproduz os sistemas biológicos. Deve-se ressaltar que, para uma análise confiável da estrutura secundária, é necessário conhecer a concentração da solução de proteína e utilizar o instrumento devidamente calibrado e operado (KELLY; JESS; PRICE, 2005).

Para determinar a presença da estrutura secundária ordenada, as proteínas recombinantes purificadas foram dialisadas contra solução de $10 \mathrm{mM}$ de tampão sódio-fosfato $\mathrm{pH} 7,4$ a $4{ }^{\circ} \mathrm{C}$ e mantidas sob refrigeração até o momento da coleta dos espectros de dicroísmo circular (CD). Foram colhidos cinco espectros de cada proteína recombinante e as médias resultantes estão representadas nos gráficos da figura 5. Todas as proteínas recombinantes apresentaram espectros típicos de estrutura secundária regular e indicam, portanto, que possuem integridade estrutural e que o processo de purificação e renaturação das proteínas insolúveis e também da purificação das proteínas solúveis foi adequado.

As análises de dicroísmo circular também demonstraram a presença de estruturas $\alpha$ hélice e randômica nas proteínas recombinantes Lp25, Lp11, Lp21, Lp22 e LigAc, uma predominância de estrutura randômica e folha $\beta$-pregueada nas proteínas Lp35 e Lp30. Estes dados estão de acordo com a predição teórica da estrutura secundária realizada pelo programa GOR4 (COMBET et al., 2000) para cada proteína recombinante (Tabela 6). 

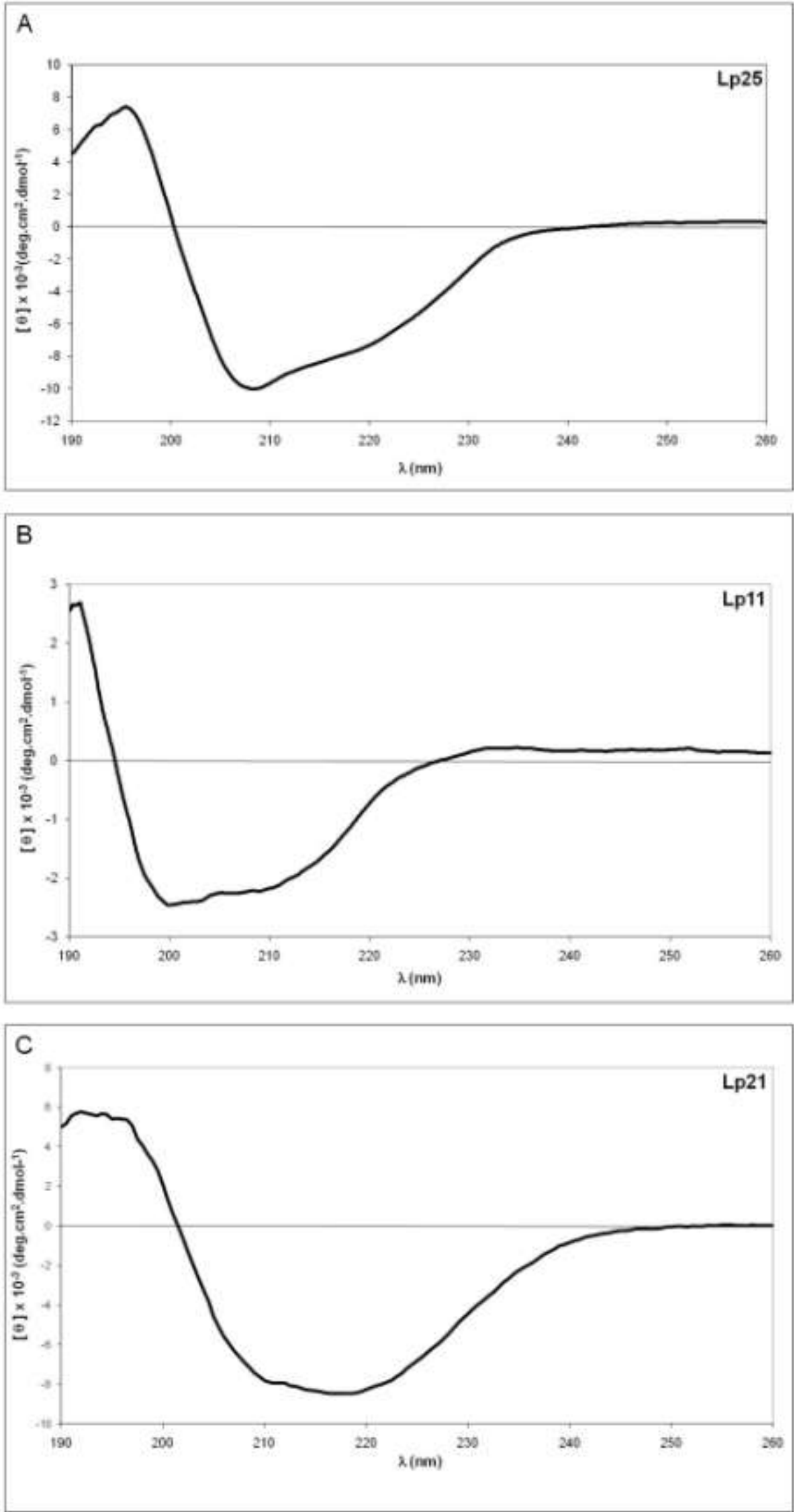

Figura 5 (parte I): Espectros de dicroísmo circular obtidos para as proteínas recombinantes. A) Lp25; B) Lp11; C) Lp21. Foram utilizadas amostras das proteínas purificadas e dialisadas contra tampão fosfato $\mathrm{pH} 7,4$. 

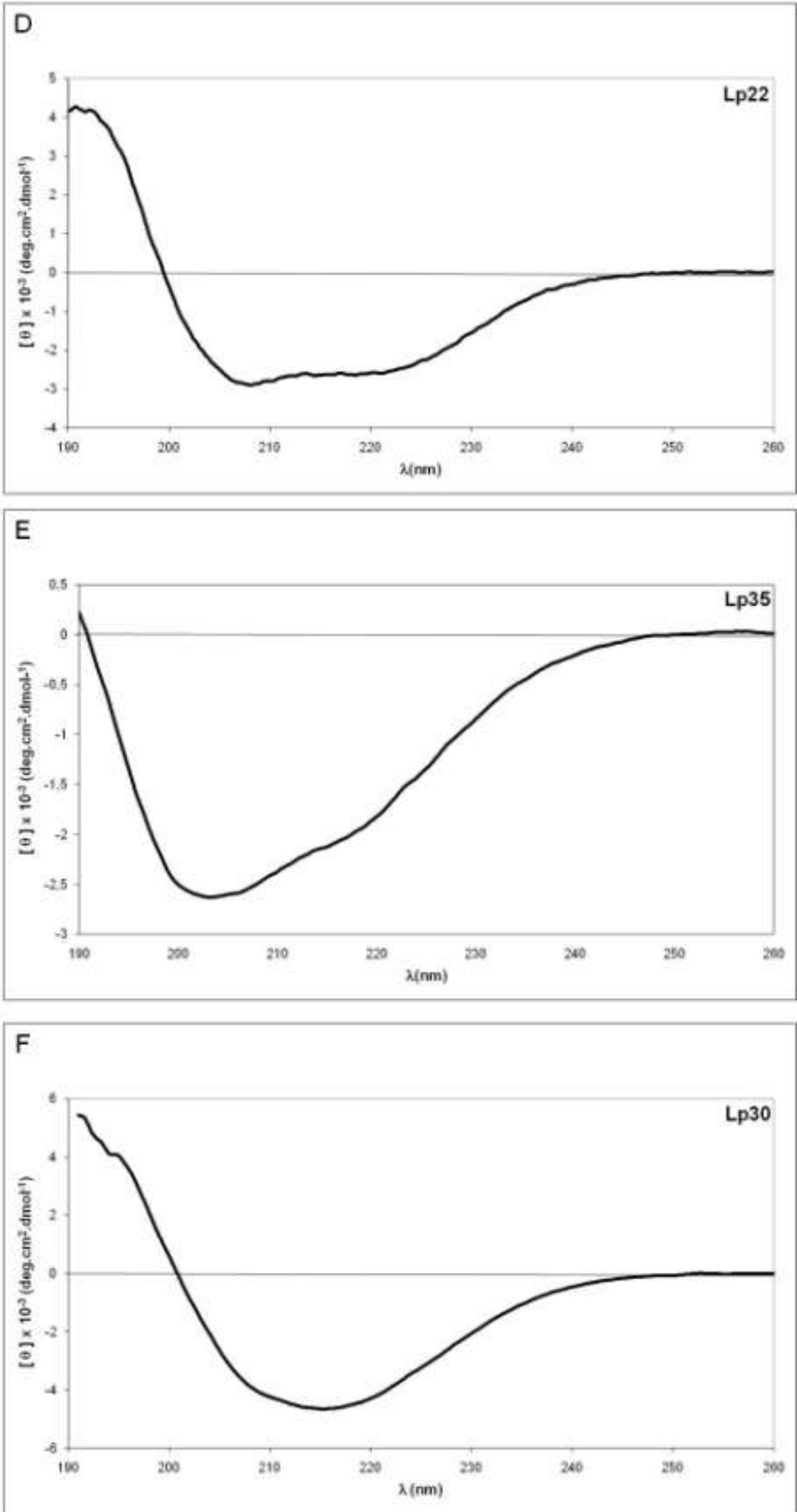

Figura 5 (parte II): Espectros de dicroísmo circular obtidos para as proteínas recombinantes. D) Lp22; E) Lp35; F) Lp30. Foram utilizadas amostras das proteínas purificadas e dialisadas contra tampão fosfato $\mathrm{pH} 7,4$. 

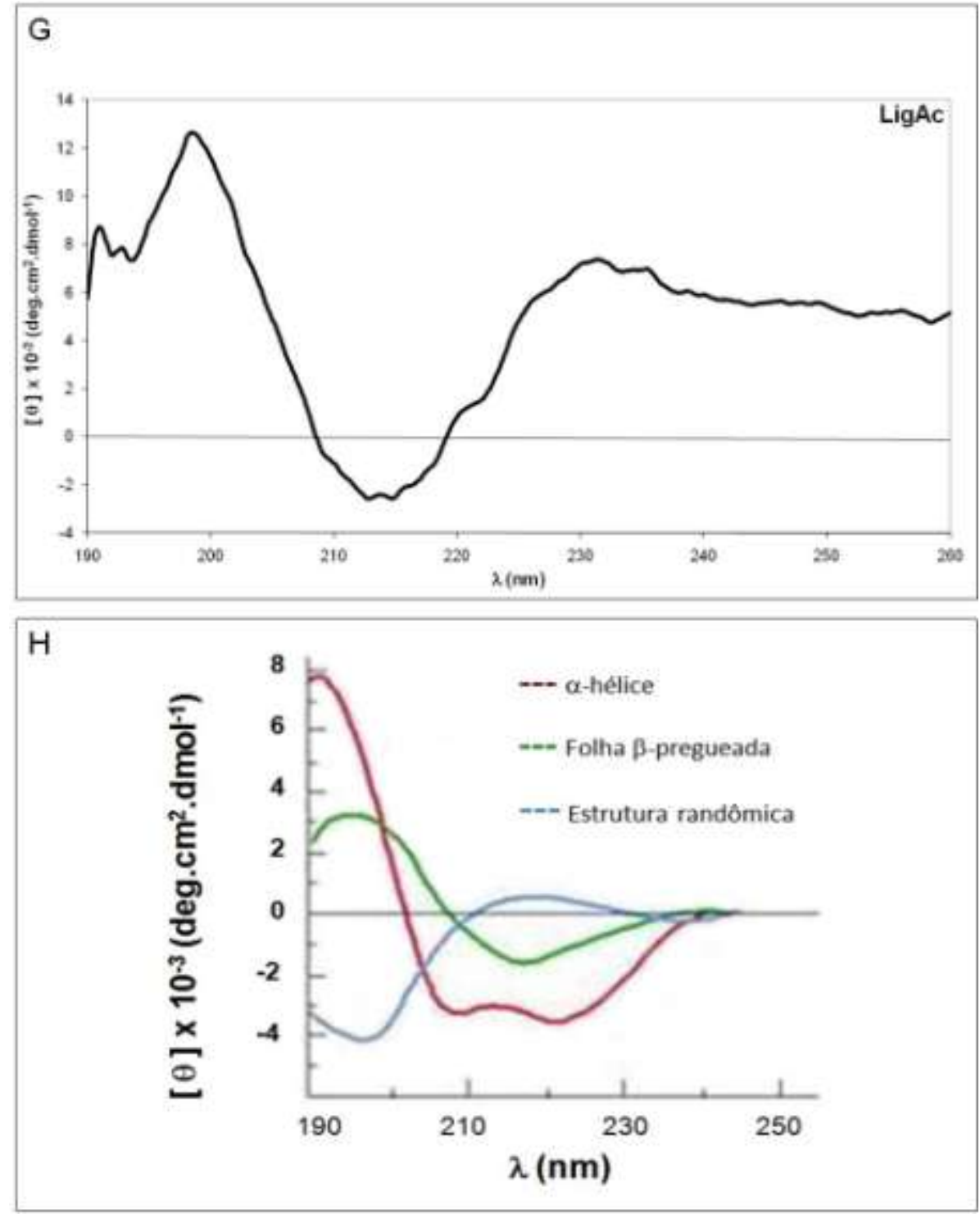

Figura 5 (parte III): Espectros de dicroísmo circular obtidos para as proteínas recombinantes. G) LigAc e H) Padrões típicos de estrutura secundária de proteínas obtidos por CD. Foram utilizadas amostras das proteínas purificadas e dialisadas contra tampão fosfato $\mathrm{pH} 7,4$.

Fonte: Kelly; Jess; Price, (2005) com modificações.

Tabela 6 - Predição teórica da estrutura secundária das proteínas recombinantes.

\begin{tabular}{cccc}
\hline \multirow{2}{*}{$\begin{array}{c}\text { Proteina } \\
\text { Recombinante }\end{array}$} & \multicolumn{3}{c}{ Predição Teórica da Estrutura Secundária (Programa GOR4) } \\
\cline { 2 - 4 } & $\alpha$-hélice (\%) & Folha $\beta$-pregueada (\%) & Estrutura randômica (\%) \\
\hline Lp25 & 30,09 & 21,03 & 48,07 \\
\hline Lp11 & 47,22 & 11,67 & 41,67 \\
\hline Lp21 & 33,67 & 18,59 & 47,74 \\
\hline Lp22 & 50,48 & 5,24 & 44,29 \\
\hline Lp35 & 0 & 21,83 & 64,60 \\
\hline Lp30 & 18,31 & 22,89 & 58,80 \\
\hline LigAc & 14,93 & 32,50 & 52,57 \\
\hline
\end{tabular}




\subsection{Obtenção da flagelina FliCi}

A flagelina FliCi de S. enterica sorovar Thyphimurium foi obtida a partir do sobrenadante de cultura precipitado com acetona. A fração de flagelina foi submetida a aquecimento a $65{ }^{\circ} \mathrm{C}$, por 30 minutos, para promover a despolimerização do filamento flagelar.

$\mathrm{Na}$ figura 6, é possível observar uma banda única (50 kDa) correspondente ao monômero de flagelina em gel de poliacrilamida SDS-PAGE 15\%. A concentração da amostra foi determinada através de método colorimétrico (Bradford) e a estimativa do rendimento da flagelina FliCi purificada foi de $20 \mathrm{mg} / \mathrm{L}$.

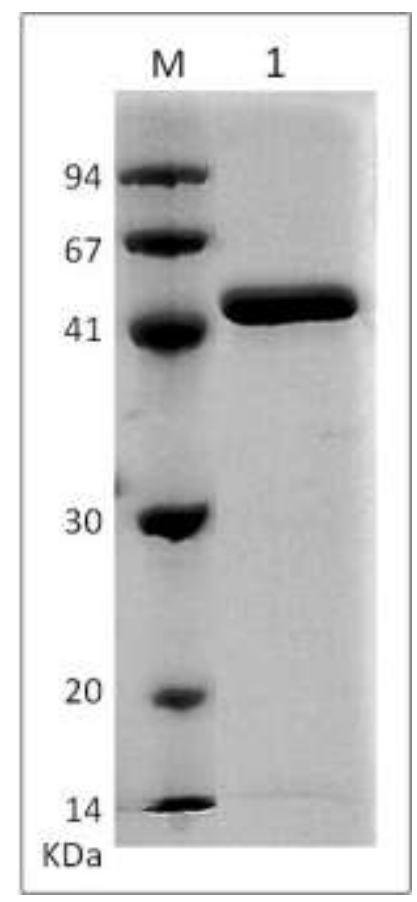

Figura 6: Proteína purificada do flagelo de S. Thyphimurium em gel SDS-PAGE $15 \%$. M - Marcador de peso molecular LMW (BioRad); 1 - Flagelina FliC $i$. 


\subsection{Ensaios de imunoproteção em modelo animal}

A segunda etapa deste trabalho foi a avaliação do potencial adjuvante da flagelina FliCi de $S$. enterica sorovar Thyphimurium na indução de resposta imunoprotetora em uma formulação vacinal composta pela proteína LigAc e/ou por seis prováveis lipoproteínas recombinantes de L. interrogans sorovar Copenhageni.

Foram realizados três ensaios de imunização e desafio com grupos de 10 hamsters imunizados subcutaneamente com uma mistura de seis lipoproteínas recombinantes purificadas na ausência e presença de LigAc recombinante. Foram testados como adjuvantes a flagelina FliCi e o hidróxido de alumínio. Os animais dos grupos controle negativos foram imunizados com PBS acrescido de FliCi ou hidróxido de alumínio, nas mesmas quantidades usadas nos grupos experimentais. Como controles positivos, animais foram imunizados com vacina comercial, LigAc ou bacterina.

As preparações vacinais contendo LigAc e bacterina foram acrescidas de $\mathrm{FliC} i$ ou hidróxido de alumínio. A vacina comercial utilizada é composta pelas culturas inativadas de seis sorovares de L. interrogans (Bratislava, Canicola, Grippotyphosa, Hardjo, Icterohaemorrhagiae, Pomona), contém hidróxido de alumínio como adjuvante e é para uso em suínos. Como controle do inóculo, um grupo de animais não foi imunizado. Todas as preparações foram diluídas em PBS. Foram realizadas duas imunizações com intervalo de 15 dias e três sangrias, um dia antes das imunizações (pré-imune e primeira sangria) e um dia antes do desafio (segunda sangria).

Os animais imunizados foram desafiados, intraperitonialmente, quinze dias após a última imunização, com $2 \times 10^{5}$ células (1000 vezes a $\mathrm{DL}_{50}$ ) de uma cultura de L. interrogans sorovar Copenhageni estirpe Fiocruz L1-130 virulenta. Os hamsters foram monitorados diariamente para acompanhamento de sinais clínicos de leptospirose. Os animais que sobreviveram após o $21^{\circ}$ dia do desafio, foram sacrificados e necropsiados. Os rins foram coletados para a detecção de Leptospira em meio EMJH modificado semi-sólido e análise histológica.

A determinação da $\mathrm{DL}_{50}$ foi feita paralelamente ao experimento de desafio. O esquema completo dos ensaios realizados está representado na figura 2 e os doze grupos utilizados estão descritos na tabela 3 em material e métodos. 


\subsection{Avaliação da Resposta Humoral}

\subsubsection{ELISA}

A análise da resposta humoral foi feita utilizando-se os soros da primeira e segunda sangria por ELISA. Os gráficos foram construídos a partir da média das absorbâncias dos três experimentos. Para não comprometer a visualização das curvas de titulação na figura 7, os desvios-padrões foram omitidos dos gráficos e estão listados no Anexo B. As médias dos títulos foram calculadas a partir da média dos valores da maior diluição do soro capaz de resultar em uma leitura de absorbância igual a 0,1 (Figura 8).

As curvas de titulação de $\operatorname{IgG}$ total dos soros dos animais dos grupos controle negativos $\left(\mathrm{PBS}+\mathrm{Al}(\mathrm{OH})_{3}\right.$ e PBS $+\mathrm{FliC} i$ ) são próximas a zero (Figura 7, partes I e II, gráficos A e B) com títulos baixos (Figura 8, gráficos A e B). Também, é possível observar a ocorrência de reconhecimento inespecífico destes soros com as proteínas recombinantes nas diluições iniciais, provavelmente devido à presença de proteínas bacterianas contaminantes na preparação vacinal decorrentes do processo de purificação, pois não foi realizada a adsorção dos soros com lisados de E. coli e S. enterica. Como esperado, os gráficos B da figura 7 , partes I e II, mostram as curvas obtidas para os soros dos animais imunizados com PBS e FliC $i$ com altos títulos de anticorpos contra a proteína $\mathrm{FliC} i$, que são maiores na segunda sangria (Figura 8, gráfico B).

A imunização dos animais com a vacina comercial foi capaz de induzir uma resposta imune humoral específica contra a bacterina do sorovar Copenhageni e contra três proteínas recombinantes avaliadas (Figura 7, partes I e II gráficos C). As proteínas Lp25, Lp11, Lp30 e Lp35 não foram reconhecidas por este soro e as proteínas Lp21, Lp22 e LigAc foram as mais imunogênicas (Figuras 8 e 9, gráficos $\mathrm{C}$ e $\mathrm{A}$, respectivamente). Os soros dos animais inoculados com a bacterina $+\mathrm{Al}(\mathrm{OH})_{3}$ ou FliC $i$ foram capazes de reconhecer as mesmas proteínas recombinantes (Figura 7, partes I e II gráficos D e E) como aconteceu com o soro dos animais inoculados com a vacina comercial e, também não houve diferença em relação ao adjuvante utilizado (Figura 8, gráficos D e E; figura 9 gráficos B e C).

Estes resultados são inesperados, pois a bacterina foi preparada a partir da mesma cultura utilizada na adsorção das placas (sorovar Copenhageni) e as proteínas foram clonadas a partir do DNA extraído desta estirpe. Provavelmente, existem diferenças na expressão das lipoproteínas nativas nas condições utilizadas para o cultivo da leptospira. Os gráficos D da figura 7 (parte I e II) mostram as curvas obtidas para os soros dos animais imunizados com 
bacterina + FliC $i$ que apresentam altos títulos de anticorpos contra a proteína FliC $i$ (Figura 8, gráfico D). Os soros dos animais imunizados com a vacina comercial, bacterina $+\mathrm{FliC} i$ ou $\mathrm{Al}(\mathrm{OH})_{3}$ foram capazes de reconhecer a bacterina (Figura 7, parte I e II, gráficos C, D e E) com títulos maiores na segunda sangria (Figura 8, gráficos C, D e E ; figura 9, gráficos A, B e C).

Os soros dos animais imunizados com as preparações vacinais contendo LigAc + $\mathrm{Al}(\mathrm{OH})_{3}$ ou FliCi apresentaram curvas de titulação semelhantes contra a proteína LigAc, (Figura 7, parte I e II, gráficos F e G), com títulos maiores nos soros dos animais imunizados com alumínio como adjuvante (Figura 8, gráficos F e G). Pode-se observar também, a ocorrência de reconhecimento inespecífico destes soros com as proteínas recombinantes, provavelmente devido à presença de proteínas bacterianas contaminantes decorrentes do processo de purificação. Mesmo assim, nota-se que o perfil das curvas contra LigAc é diferente do perfil das curvas contra as outras proteínas recombinantes. Com o aumento da diluição dos soros, as curvas dos grupos negativos se aproximam de zero. Além disso, o gráfico $\mathrm{G}$ da figura 7 mostra que a curva obtida para os soros dos animais imunizados com LigAc + FliC $i$ e os títulos de anticorpos contra a proteína FliCi (Figura 8, gráfico G), assemelham-se aos do grupo $\operatorname{LigAc}+\mathrm{Al}(\mathrm{OH})_{3}$, entretanto, com títulos maiores (Gráficos $\mathrm{F}$ e $\mathrm{G}$, figuras 7 e 8 ).

A imunização dos animais com o pool de proteínas foi capaz de induzir uma resposta imune humoral específica contra cada proteína recombinante (Figura 7, partes I e II, gráficos H, I, J, K) com diferentes graus de imunogenicidade. As proteínas mais imunogênicas foram Lp21, Lp22, Lp30 e Lp35, seguidas pelas proteínas Lp11, Lp25, nos grupos imunizados com o pool $+\mathrm{FliC} i$, enquanto nos grupos imunizados com pool $+\mathrm{Al}(\mathrm{OH})_{3}$ a proteína que apresentou maior título foi a Lp21 (Figura 8 gráfico H). Em todos os casos houve um aumento nos títulos dos anticorpos contra as proteínas recombinantes com a segunda imunização.

Os títulos obtidos foram maiores nos grupos imunizados com o pool + FliCi em comparação aos grupos imunizados com $\mathrm{Al}(\mathrm{OH})_{3}$ (Figura 8, gráficos $\mathrm{H}$ e I). Estes resultados são comparáveis aos obtidos com os soros dos animais imunizados com o pool + LigAc, tanto em relação ao reconhecimento individual das proteínas como nos títulos dos soros dos animais imunizados (Gráficos $\mathrm{J}$ e $\mathrm{K}$ das figuras 7 e 8). Os títulos dos soros dos animais imunizados com pool $+\mathrm{LigAc}+\mathrm{Al}(\mathrm{OH})_{3}$ foram maiores contra a proteína LigAc em comparação aos títulos da mesma preparação vacinal contendo FliC $i$ como adjuvante (Figura 8, gráficos J e K). 
Em conjunto, os resultados obtidos por ELISA indicam que os soros dos animais imunizados com as diferentes preparações vacinais na presença $\mathrm{FliC} i$ apresentam títulos de anticorpos maiores contra as proteínas recombinantes ou bacterina do que quando o hidróxido de alumínio administrado como adjuvante.
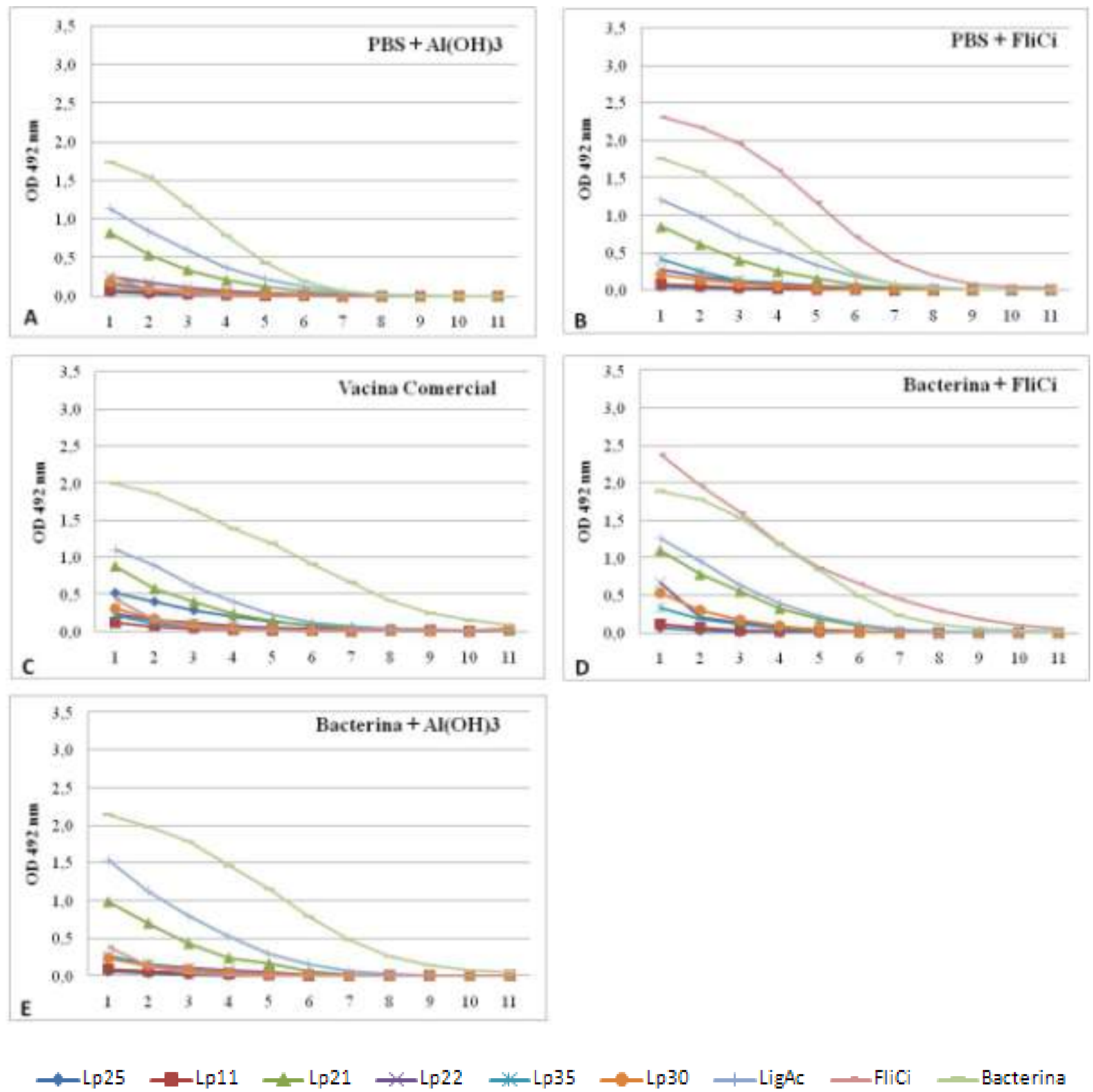

Figura 7 (parte I): Curvas de titulação de IgG total obtidas por ELISA utilizando os soros da primeira sangria. Os gráficos foram construídos a partir da média das absorbâncias dos três ensaios de imunização e desafio. Inverso das diluições usadas: 1- 100; 2-200; 3 400; 4- 800; 5- 1.600; 6- 3.200; 7- 6.400; 8- 12.800; 9- 25.600; 10- 51.200; 11102.400. Para não comprometer a visualização dos gráficos, os desvios-padrões foram omitidos e estão listados no ANEXO B. 

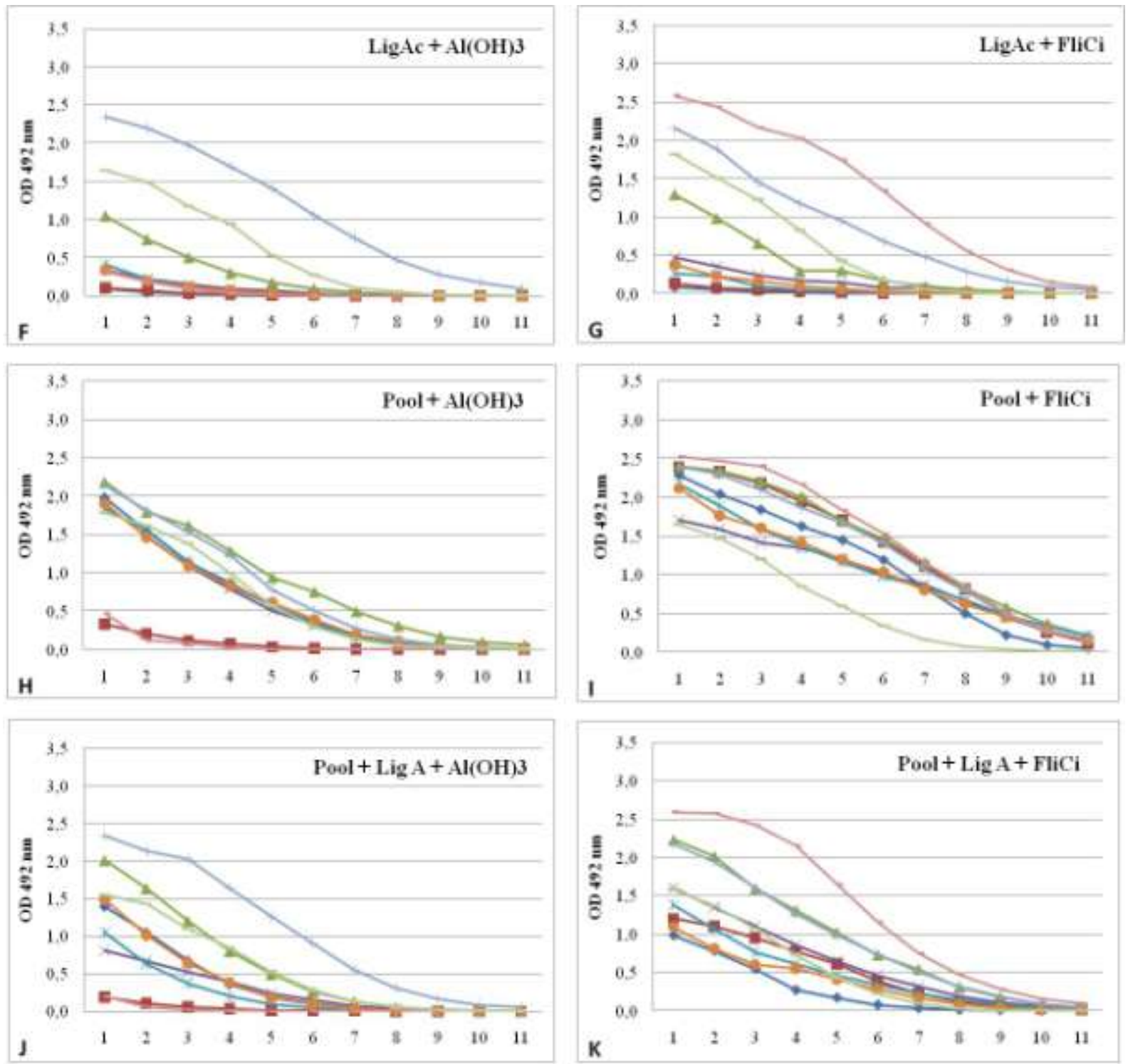

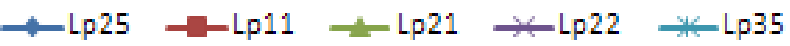

-Lp30 - LigAc - FliCi - Bacterina

Figura 7 (continuação da parte I): Curvas de titulação de IgG total obtidas por ELISA utilizando os soros da primeira sangria. Os gráficos foram construídos a partir da média das absorbâncias dos três ensaios de imunização e desafio. Inverso das diluições usadas: 1- 100; 2-200; 3- 400; 4800; 5- 1.600; 6- 3.200; 7- 6.400; 8- 12.800; 9- 25.600; 10 51.200; 11- 102.400. Para não comprometer a visualização dos gráficos, os desvios-padrões foram omitidos e estão listados no ANEXO B. 

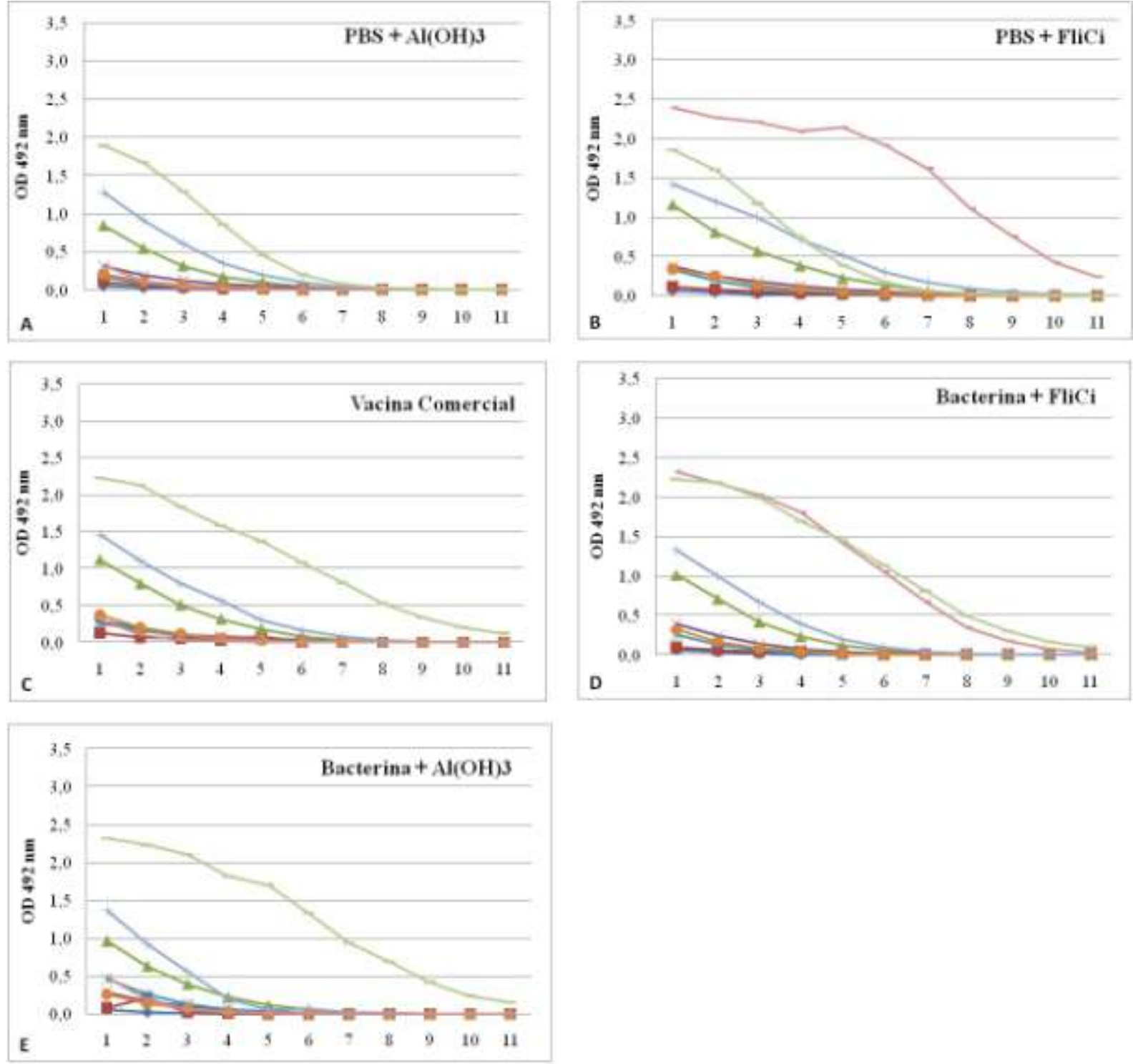

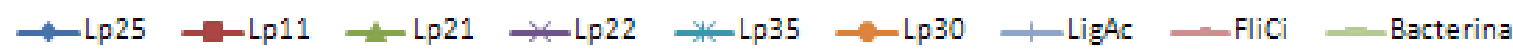

Figura 7 (parte II): Curvas de titulação de IgG total obtidas por ELISA utilizando os soros da segunda sangria. Os gráficos foram construídos a partir da média das absorbâncias dos três ensaios de imunização e desafio. Inverso das diluições usadas: 1- 100; 2-200; 3- 400; 4- 800; 5- 1.600; 6- 3.200; 7- 6.400; 8- 12.800; 9- 25.600; 10- 51.200; 11 102.400. Para não comprometer a visualização dos gráficos, os desvios-padrões foram omitidos e estão listados no ANEXO B. 

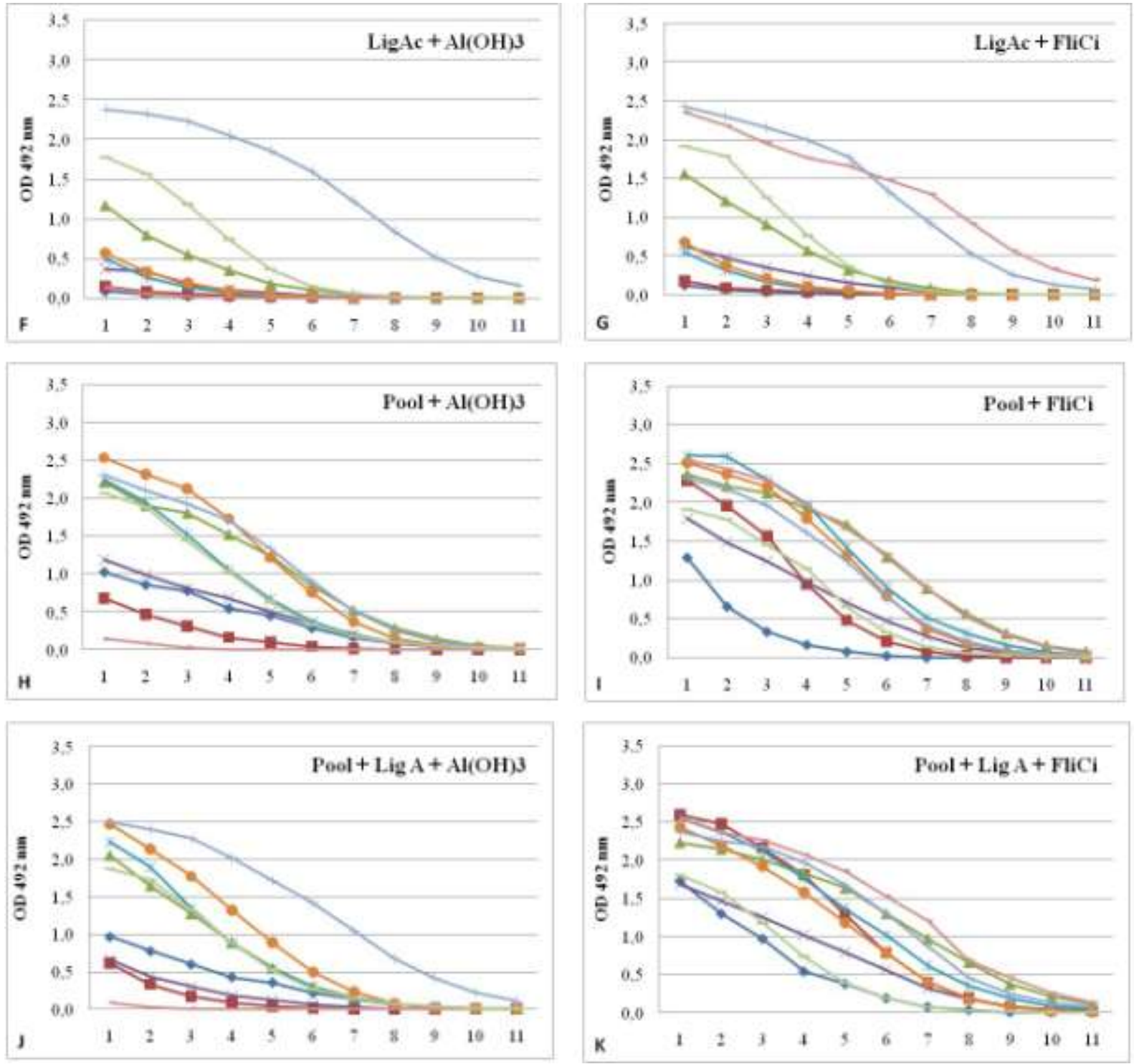

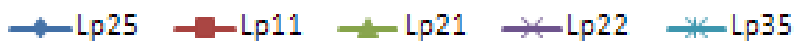

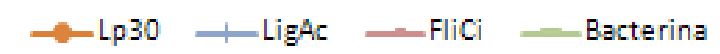

Figura 7 (continuação da parte II): Curvas de titulação de IgG total obtidas por ELISA utilizando os soros da segunda sangria. Os gráficos foram construídos a partir da média das absorbâncias dos três ensaios de imunização e desafio. Inverso das diluições usadas: 1- 100; 2-200; 3- 400; 4800; 5- 1.600; 6- 3.200; 7- 6.400; 8- 12.800; 9- 25.600; 1051.200; 11- 102.400. Para não comprometer a visualização dos gráficos, os desvios-padrões foram omitidos e estão listados no ANEXO B. 

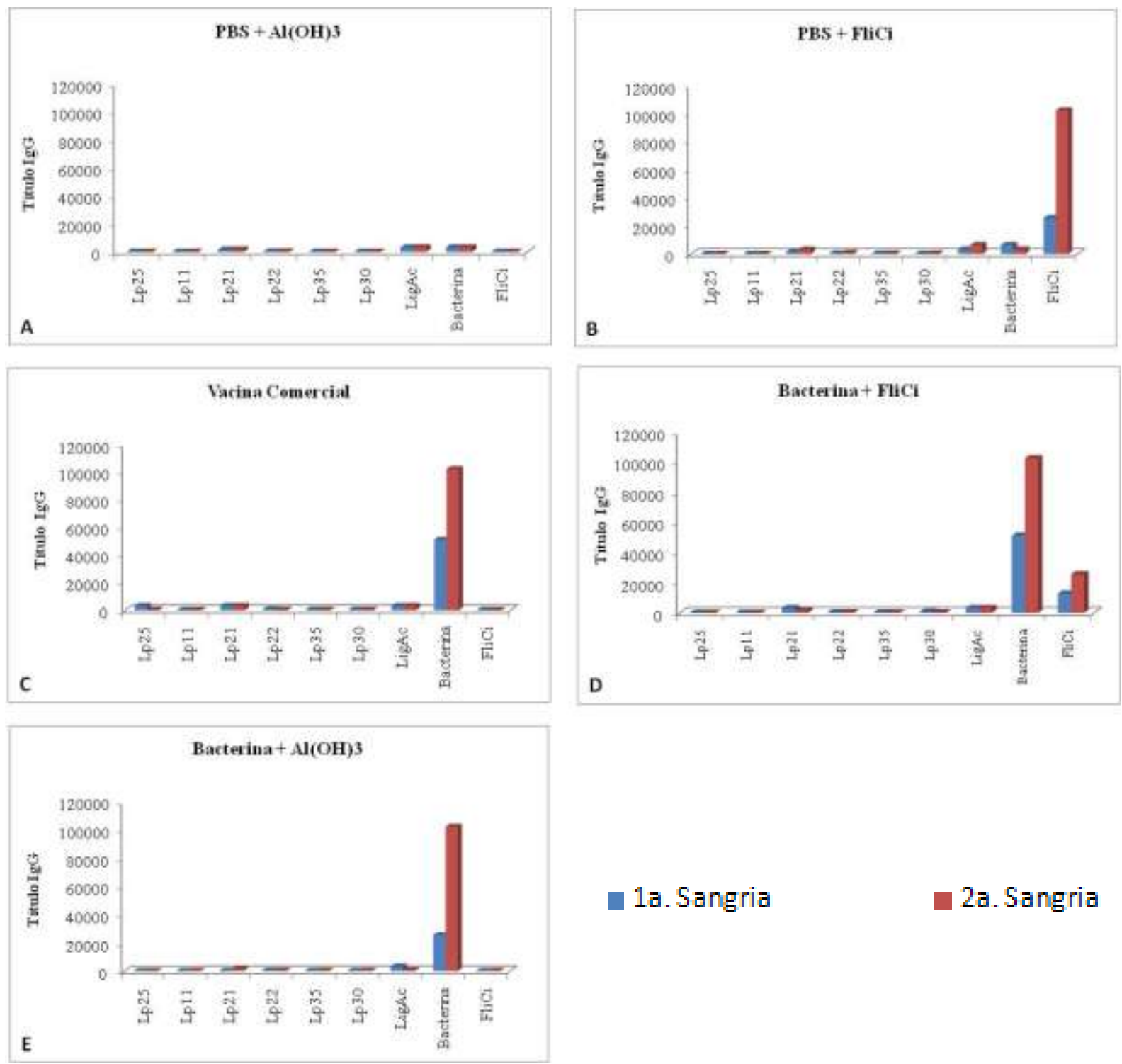

1a. Sangria

2a. Sangria

Figura 8 (parte I): Títulos dos soros obtidos por ELISA utilizando os soros da primeira e segunda sangria. As médias dos títulos foram calculadas a partir da média dos valores da maior diluição do soro capaz de resultar em uma leitura de absorbância igual a 0,1 dos três ensaios de imunização e desafio. 

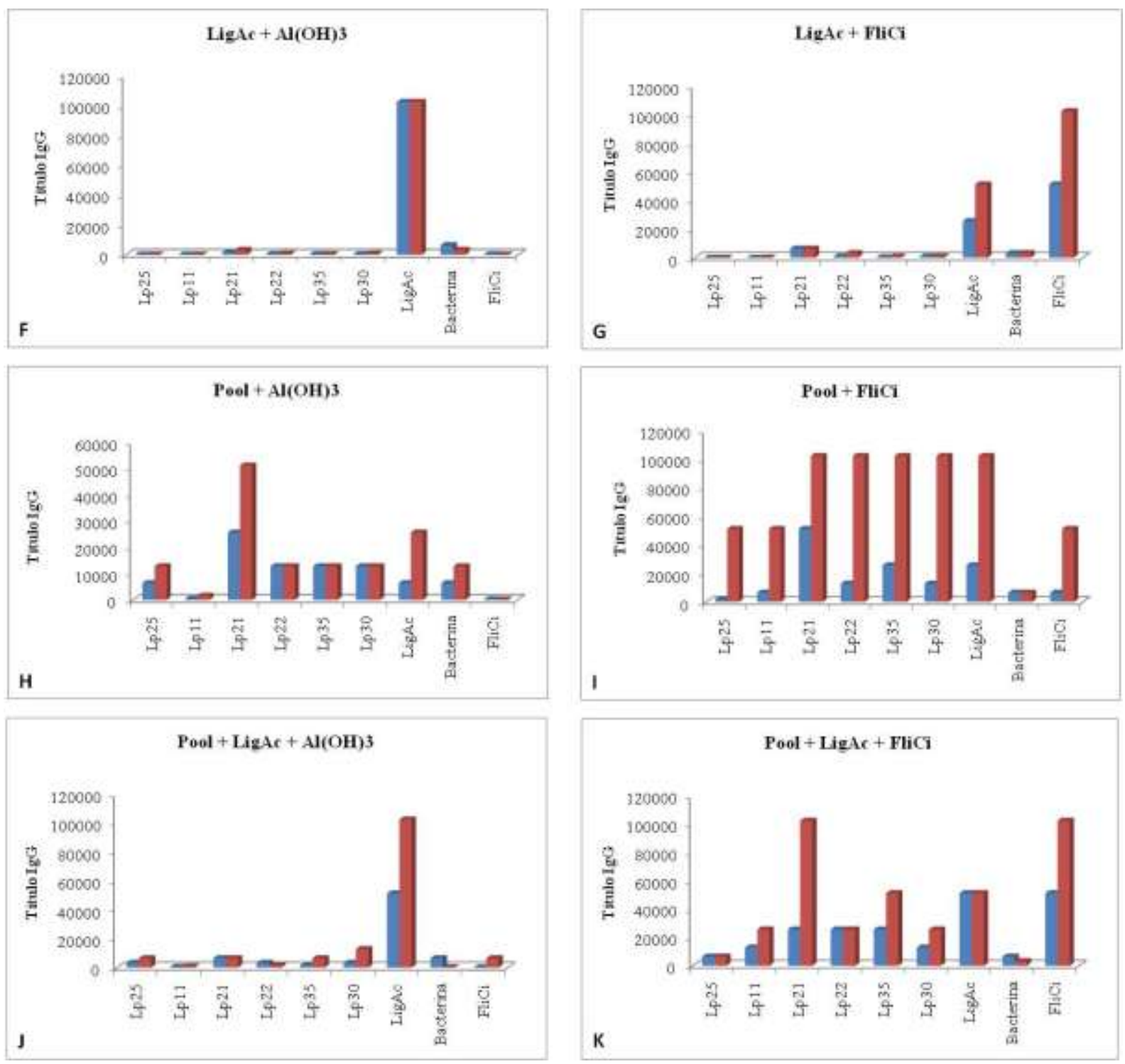

1a. Sangria

2a. Sangria

Figura 8 (parte II): Títulos dos soros obtidos por ELISA utilizando os soros da primeira e segunda sangria. As médias dos títulos foram calculadas a partir da média dos valores da maior diluição do soro capaz de resultar em uma leitura de absorbância igual a 0,1 dos três ensaios de imunização e desafio. 

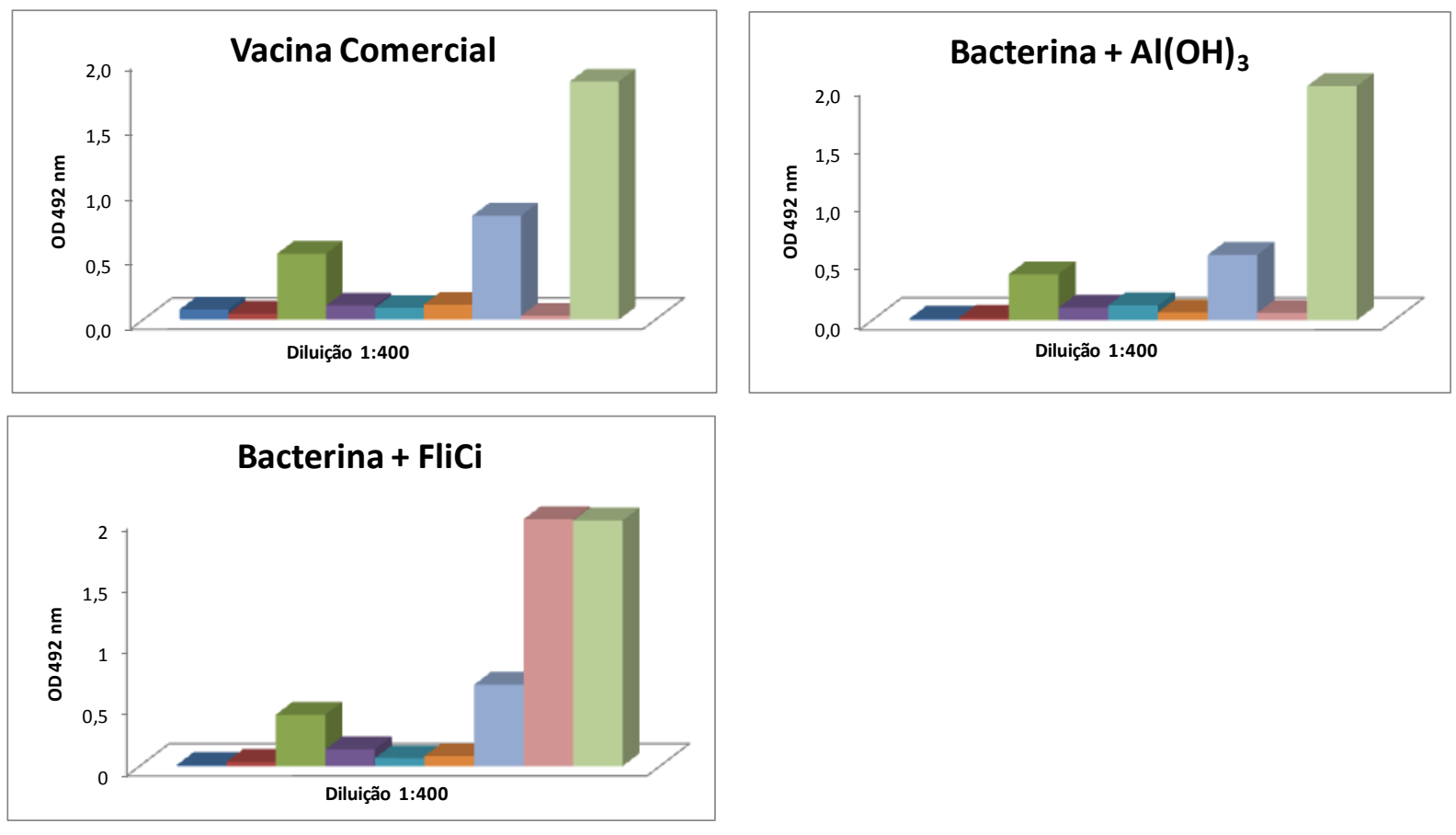

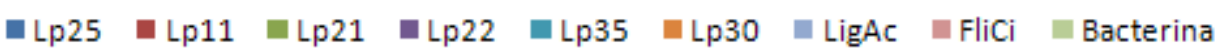

Figura 9: Valores de absorbância a $492 \mathrm{~nm}$ obtidos por ELISA, utilizando soros dos animais diluídos 1:400. As placas de microdiluição foram adsorvidas com $10 \mu \mathrm{g} / \mathrm{mL}$ de proteína total da preparação bacterina.

\subsubsection{Western-Blotting}

A especificidade do reconhecimento das proteínas recombinantes pelos soros dos animais imunizados com o pool de proteínas foi confirmada por western-blotting utilizando os soros da segunda sangria do primeiro ensaio. As proteínas recombinantes purificadas (Lp25, Lp11, Lp21, Lp22, Lp35, Lp30 e LigAc) e FliCi foram submetidas à eletroforese, transferidas para uma membrana de nitrocelulose e coradas com Ponceau (Figura 10A). Foram preparadas três membranas iguais e cada uma foi incubada com um soro diferente (Figura 10B, C e D). Uma membrana foi feita utilizando-se somente a proteína LigAc (Figura 11A e B).

A figura $10 \mathrm{D}$ mostra que os soros dos hamsters imunizados com o pool $+\mathrm{Al}(\mathrm{OH})_{3}$ foram específicos ao reconhecer as bandas correspondentes às proteínas recombinantes e não reconheceram a banda da proteína $\mathrm{FliC} i$ que não estava presente na preparação vacinal. Os soros dos animais imunizados com $\mathrm{PBS}+\mathrm{Al}(\mathrm{OH})_{3}$ ou FliC $i$ não foram capazes de reconhecer as bandas das proteínas recombinantes e como esperado os soros dos animais imunizados com PBS + FliC $i$ reconheceram especificamente a banda correspondente a FliCi. Os soros dos 
animais imunizados com preparações vacinais contendo a proteína LigAc reconheceram especificadamente a banda correspondente à FliCi (Figura 11B, canaletas 3 a 7) e, como esperado, os soros dos animais imunizados com preparações vacinais sem $\mathrm{FliC} i$ não foram capazes de reconhecer esta proteína (Figura 11B, canaletas 2, 8, 9 e 10).

Estes resultados demonstram a especificidade do reconhecimento das proteínas recombinantes pelos soros dos animais imunizados com o pool de proteínas e confirmam os dados obtidos por ELISA.

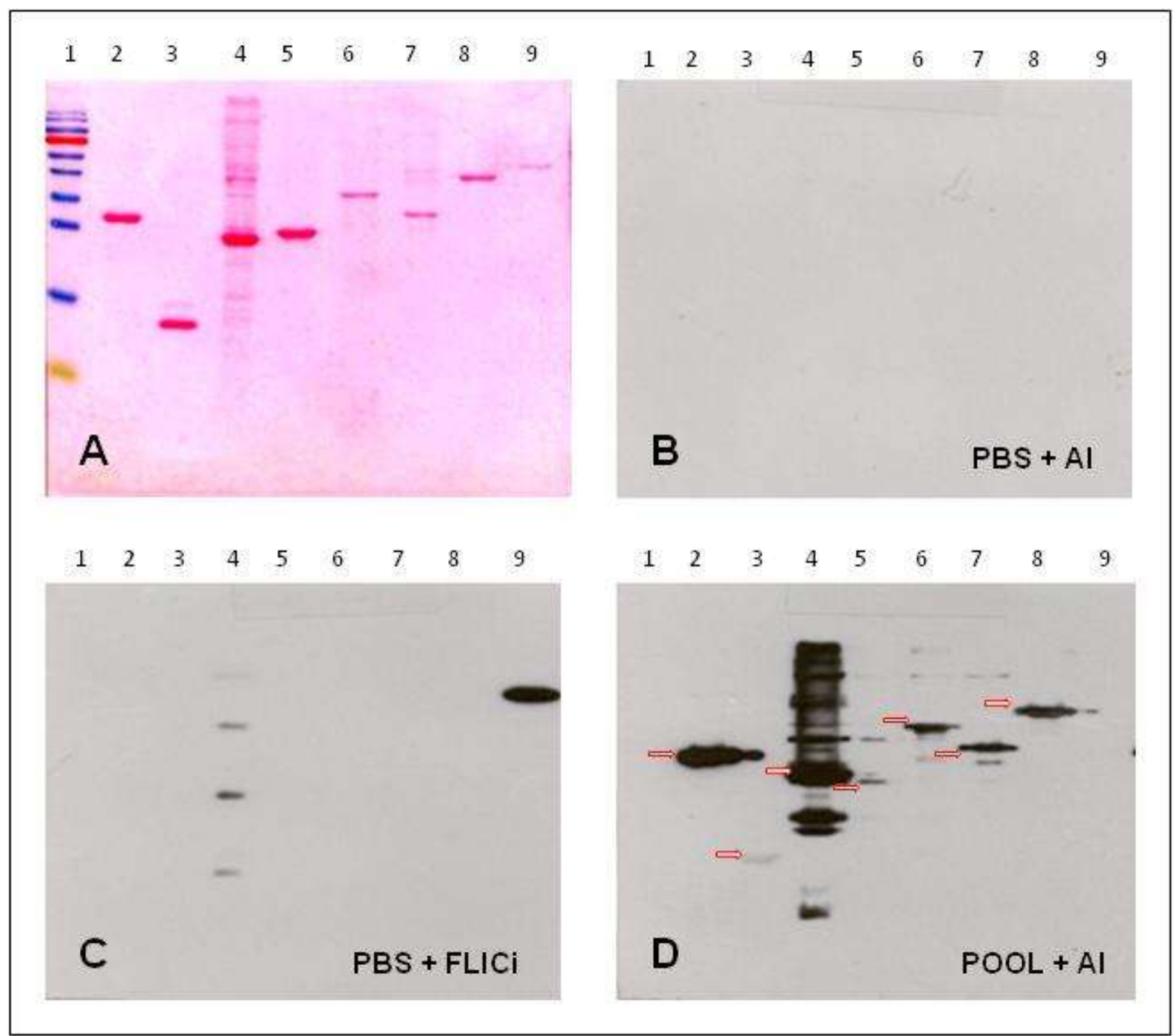

Figura 10: Western blotting das proteínas recombinantes utilizando os soros dos animais diluídos 1:1000. A) Membrana de nitrocelulose corada com Ponceau S. 1- Padrão de peso molecular; 2- Lp25; 3- Lp11; 4- Lp21; 5- Lp22; 6- Lp35; 7- Lp30; 8- LigAc; 9-FliCi; B) Proteínas incubadas com soro $\mathrm{PBS}+\mathrm{Al}(\mathrm{OH})^{3}$; C) Proteínas incubadas com soro PBS+FliC $i$; D) Proteínas incubadas com soro Pool+ $\mathrm{Al}(\mathrm{OH})^{3}$; (Filme Hyperfilm, detecção por ECL). 


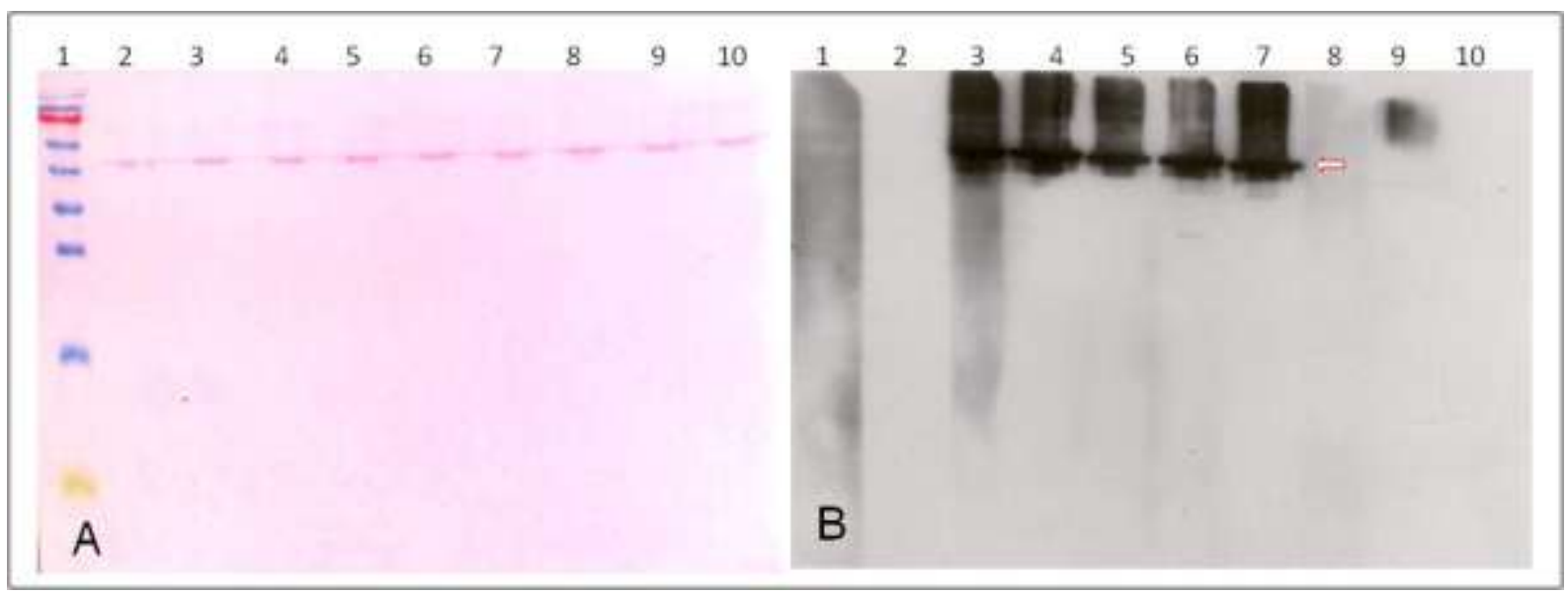

Figura 11: Western blotting da proteína LigAc recombinante utilizando os soros dos animais diluídos 1:1000. A) Membrana de nitrocelulose corada com Ponceau S, 1- Padrão de peso molecular; 2 a 10- LigAc recombinante. B) 2- $\mathrm{LigAc}$ incubada com soro $\mathrm{PBS}+\mathrm{Al}(\mathrm{OH})^{3}$; 3- $\mathrm{LigAc}$ incubada com soro $\mathrm{LigAc}+\mathrm{Al}(\mathrm{OH})^{3}$; 4- $\mathrm{LigAc}$ incubada com soro $\mathrm{LigAc}+\mathrm{FliC} i$; 5- LigAc incubada com soro Pool $+\mathrm{LigAc}+\mathrm{Al}(\mathrm{OH})^{3} ;$ 6- $\mathrm{LigAc}$ incubada com soro Pool+LigAc+FliCi; 7- LigAc incubada com soro Pool $+\mathrm{LigAc}+\mathrm{Al}(\mathrm{OH})^{3}+\mathrm{FliC} ;$; 8- $\mathrm{LigAc}$ incubada com soro PBS+FliCi; 9- LigAc incubada com soro Pool $+\mathrm{Al}(\mathrm{OH})^{3} ; 10$ - $\mathrm{LigAc}$ incubada com soro Pool+FliCi. (Filme Hyperfilm, detecção por ECL).

\subsection{Avaliação do potencial imunoprotetor}

O potencial imunoprotetor das seis proteínas recombinantes e/ou LigAc administradas com dois adjuvantes (hidróxido de alumínio e/ou FliC $i$ ) foi avaliado em termos de sobrevivência e colonização renal após desafio homólogo com a estirpe L. interrogans sorovar Copenhageni.

A maioria dos animais dos grupos controle negativos infectados morreram entre 6 e 19 dias após o desafio e apresentaram sintomas clínicos de leptospirose como desidratação, anorexia e diminuição da atividade (Figura 12, gráficos A, D e G). Considerando o número total de sobreviventes dos três ensaios realizados, o grupo controle do inóculo, PBS + $\mathrm{Al}(\mathrm{OH})_{3}$ e PBS + FliCi apresentaram na média $0 \%, 10 \%$ e $10 \%$ de sobrevivência, respectivamente (Tabela 7), enquanto os grupos imunizados com a vacina comercial, bacterina $+\mathrm{Al}(\mathrm{OH})_{3}$ e Bacterina $+\mathrm{FliC} i$, apresentaram na média 97\%, $90 \%$ e $100 \%$ de sobrevivência, respectivamente. Os animais destes grupos não apresentavam sinais clínicos aparentes da doença (Figura 12, gráficos B, E e H; tabela 7). 
Os animais imunizados com as preparações vacinais que continham LigAc, independente do adjuvante usado, apresentaram na média 93 a 100\% de sobrevivência ao desafio; apenas no grupo LigA + FliCi dois animais morreram (Figura 12, gráficos C, F e I, tabela 7). Por outro lado, os animais imunizados com o pool $+\mathrm{Al}(\mathrm{OH})_{3}$ foram parcialmente protegidos contra o desafio (50\% de sobrevivência) e a maioria dos animais imunizados com o pool + FliCi morreu entre 6 e 15 dias após o desafio com sintomas clínicos de leptospirose (3\% de sobrevivência) (Figura 12, gráficos C, F e I, tabela 7). 

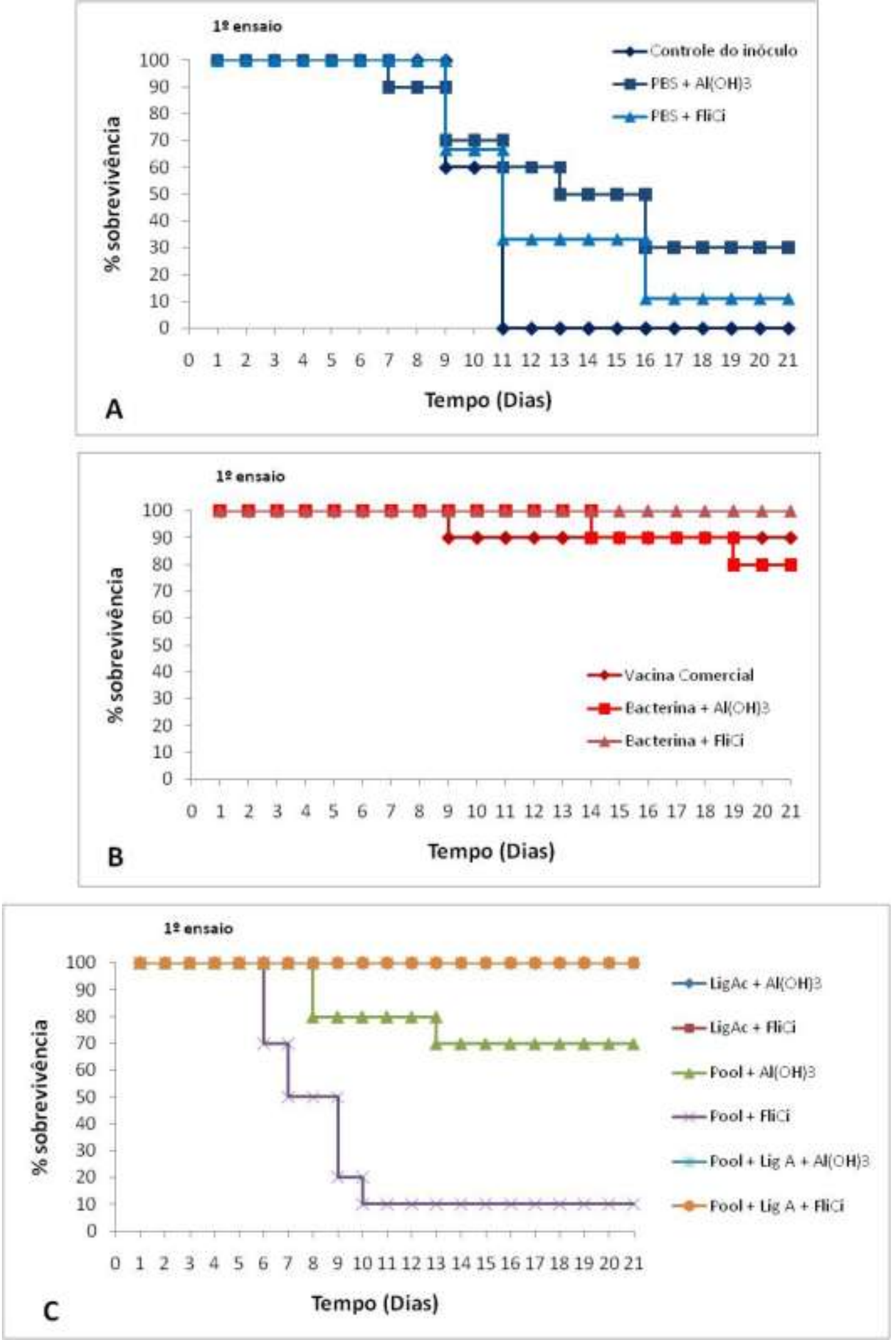

Figura 12 (parte I): Porcentagem de hamsters sobreviventes durante 21 dias após desafio com uma cultura de L. interrogans sorovar Copenhageni virulenta. A, B e C: Primeiro desafio. 

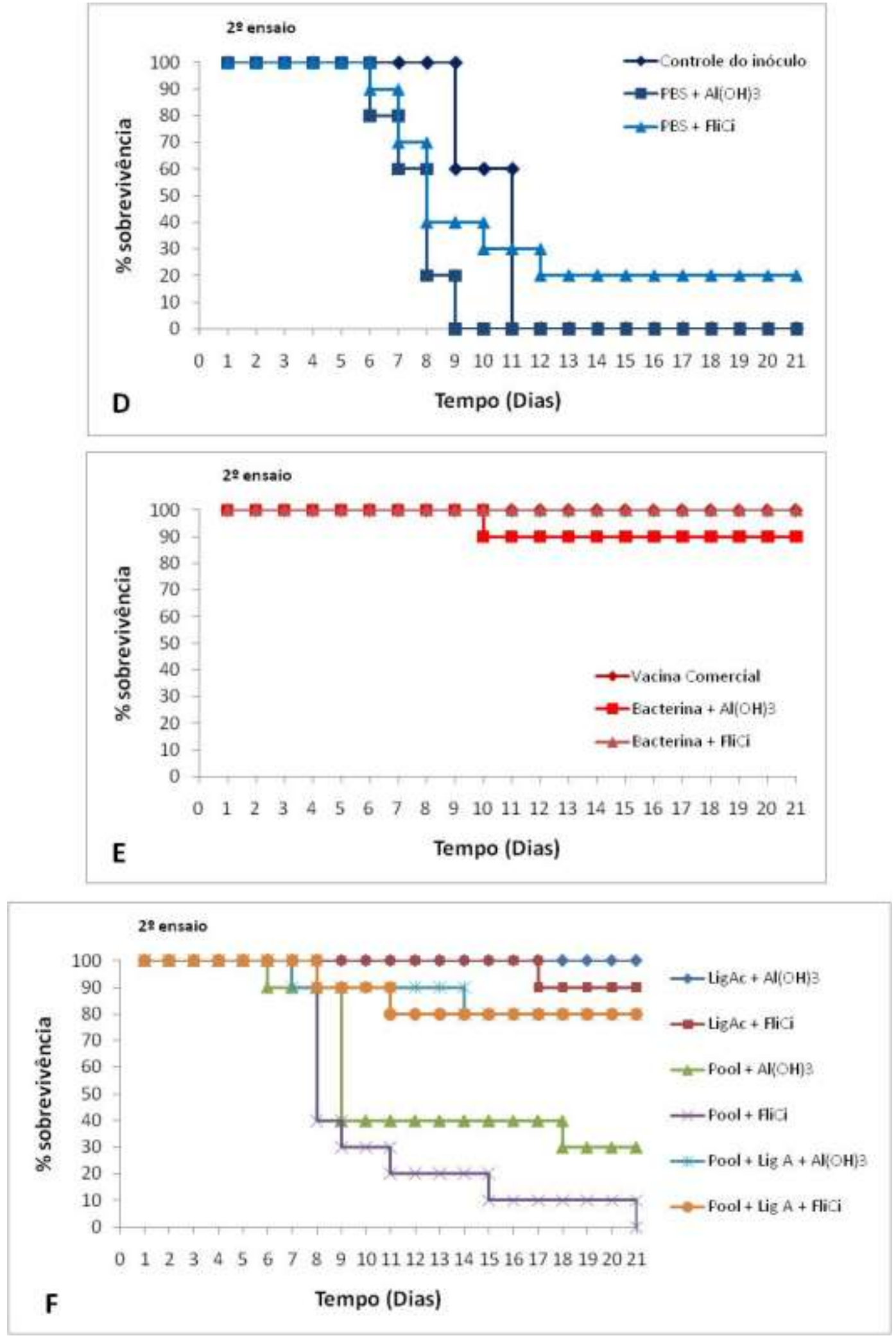

Figura 12: (parte II) Porcentagem de hamsters sobreviventes durante 21 dias após desafio com uma cultura de L. interrogans sorovar Copenhageni virulenta. D, E e F: Segundo desafio. 

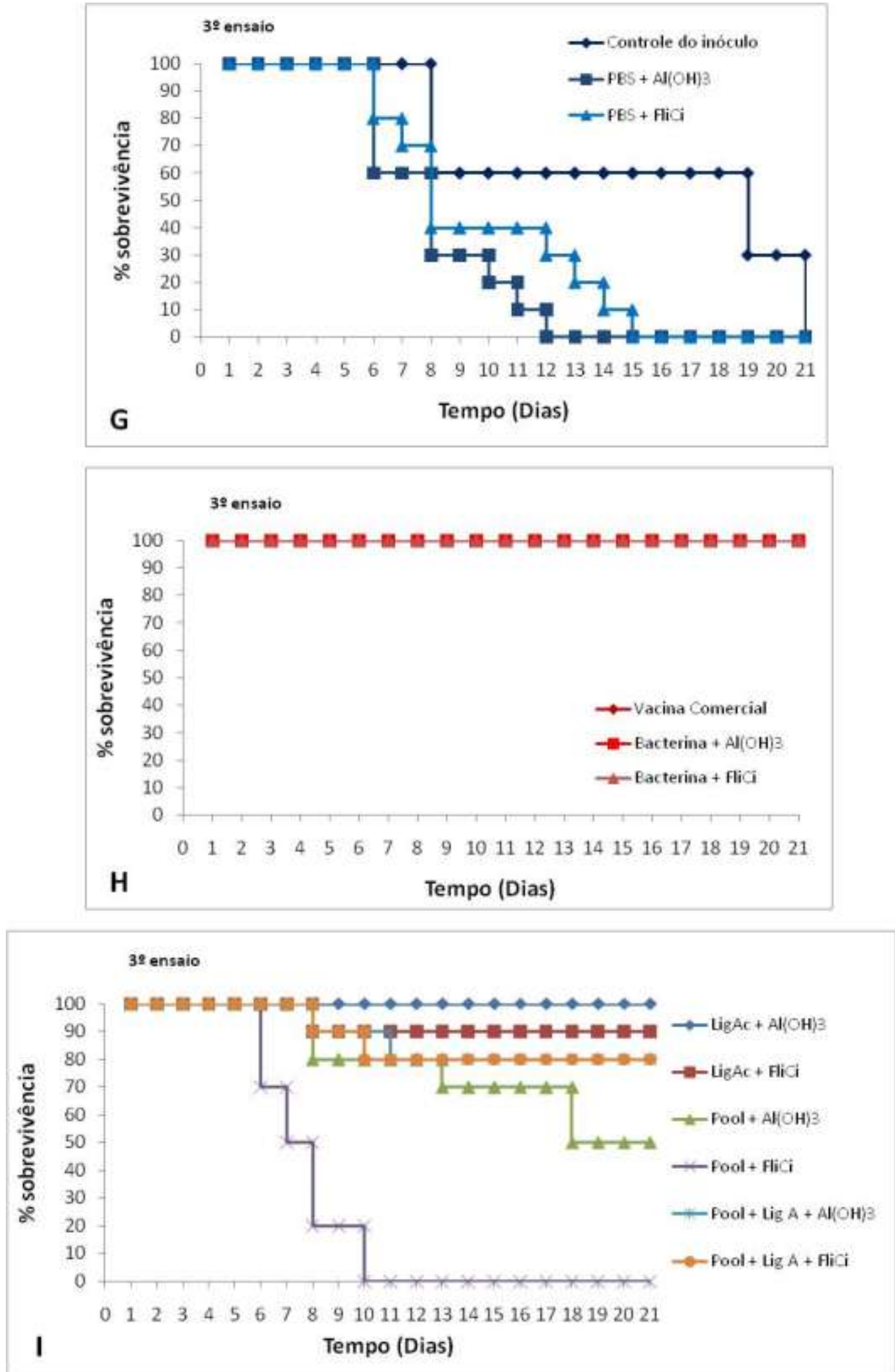

Figura 12: (parte III) Porcentagem de hamsters sobreviventes durante 21 dias após desafio com uma cultura de $L$. interrogans sorovar Copenhageni virulenta. G, H e I: Terceiro desafio. 
Tabela 7 - Proteção conferida pela imunização de hamsters desafiados com L. interrogans Copenhageni.

\begin{tabular}{|c|c|c|c|c|c|}
\hline \multirow{2}{*}{ Grupos } & \multicolumn{4}{|c|}{ Animais Sobreviventes / Total } & \multirow{2}{*}{ Sobrevivência } \\
\hline & $1^{o}$ Ensaio & $2^{\circ}$ Ensaio & $3^{\circ}$ Ensaio & Somatória & \\
\hline 01- Controle do inóculo & $00 / 10$ & $00 / 10$ & $00 / 10$ & $00 / 30$ & $0 \%$ \\
\hline $02-\mathrm{PBS}+\mathrm{Al}(\mathrm{OH})_{3}$ & $03 / 10$ & $00 / 10$ & $00 / 10$ & $03 / 30$ & $10 \%$ \\
\hline 03- PBS + FliCi & $01 / 10$ & $02 / 10$ & $00 / 10$ & $03 / 30$ & $10 \%$ \\
\hline 04- Vacina comercial & $09 / 10$ & $10 / 10$ & $10 / 10$ & $29 / 30$ & $97 \%$ \\
\hline 05- Bacterina $+\mathrm{Al}(\mathrm{OH})_{3}$ & $08 / 10$ & $09 / 10$ & $10 / 10$ & $27 / 30$ & $90 \%$ \\
\hline 06- Bacterina + FliC $i$ & $10 / 10$ & $10 / 10$ & $10 / 10$ & $30 / 30$ & $100 \%$ \\
\hline $07-\operatorname{LigAc}+\mathrm{Al}(\mathrm{OH})_{3}$ & $10 / 10$ & $10 / 10$ & $10 / 10$ & $30 / 30$ & $100 \%$ \\
\hline 08- LigAc + FliCi & $10 / 10$ & $09 / 10$ & $09 / 10$ & $28 / 30$ & $93 \%$ \\
\hline $09-$ Pool $+\mathrm{Al}(\mathrm{OH})_{3}$ & $03 / 10$ & $07 / 10$ & $05 / 10$ & $15 / 30$ & $50 \%$ \\
\hline 10- Pool + FliC $i$ & $01 / 10$ & $00 / 10$ & $00 / 10$ & $01 / 30$ & $3 \%$ \\
\hline $11-\mathrm{Pool}+\mathrm{LigAc}+\mathrm{Al}(\mathrm{OH})_{3}$ & $10 / 10$ & $08 / 10$ & $08 / 10$ & $26 / 30$ & $87 \%$ \\
\hline 12- Pool + LigAc + FliC $i$ & $10 / 10$ & $08 / 10$ & $07 / 09$ & $25 / 29$ & $86 \%$ \\
\hline
\end{tabular}

Os animais que sobreviveram após o $21^{\circ}$ dia do desafio foram sacrificados e necropsiados, os rins foram coletados para a detecção de Leptospira em meio semi-sólido de Fletcher, as culturas foram monitoradas por 28 dias e aquelas que apresentaram crescimento visível foram consideradas positivas, como é possível observar na figura 13. Estes resultados foram confirmados, através da visualização de leptospiras em cortes dos rins dos animais sobreviventes. As amostras foram processadas para exame histológico, através da coloração pela prata pelo método de Warthin-Starry. Nesta coloração, as leptospiras se coram de marrom escuro ou negro e o fundo adquire uma cor amarelada.

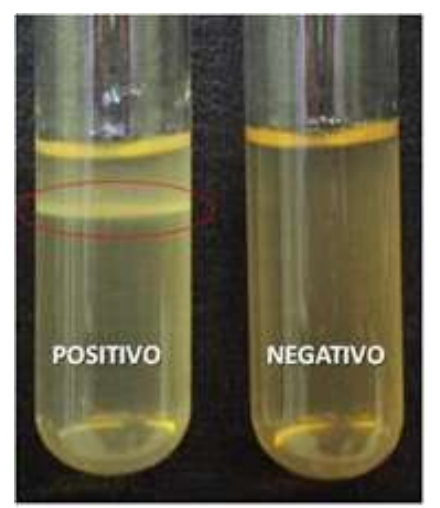

Figura 13: Macerado de rim em meio semi-sólido de Fletcher. O circulo vermelho indica o anel de crescimento bacteriano após 28 dias do inóculo. 
Todos os animais imunizados com PBS $+\mathrm{Al}(\mathrm{OH})_{3}$ e PBS + FliC $i$ que sobreviveram ao desafio foram positivos para a presença de leptospiras nos rins, enquanto a maioria dos animais dos grupos controle positivos (vacina comercial, bacterina $+\mathrm{Al}(\mathrm{OH})_{3}$ e bacterina + FliCi) não apresentou cultura e lâminas positivas para leptospira. Nos grupos imunizados com LigAc, na presença de $\mathrm{Al}(\mathrm{OH})_{3}$, todos os animais sobreviventes foram positivos quanto à cultura do macerado dos rins, enquanto na presença de FliCi $7 \%$ dos animais foram negativos (Tabela 8). Todos os animais imunizados com o pool $+\operatorname{LigAc}+\mathrm{Al}(\mathrm{OH})_{3}$ que sobreviveram ao desafio foram positivos para a presença de leptospiras nos rins, enquanto aproximadamente $72 \%$ dos animais imunizados com pool + LigAc + FliC $i$ foram negativos para a colonização renal (Tabela 8).

Estes resultados foram confirmados pela observação das lâminas de cortes renais corados pela prata. Na figura 14, parte I (A e B) são mostrados exemplos de lâminas dos rins dos animais imunizados com $\mathrm{PBS}+\mathrm{Al}(\mathrm{OH})_{3}$ e PBS + FliC $i$ que sobreviveram ao desafio, confirmando a presença de leptospiras nos túbulos renais. Da mesma maneira que nos grupos imunizados com LigAc, os animais foram positivos para a presença de leptospiras (lâminas C e D). Enquanto nas lâminas dos cortes renais dos animais dos grupos controle positivos (vacina comercial, bacterina $+\mathrm{Al}(\mathrm{OH})_{3}$ e bacterina $+\mathrm{FliC} i$ ) não foram observadas leptospiras (Figura 14, parte III, lâminas I/J; K/L e parte IV lâminas M/N).

As lâminas dos cortes renais dos animais imunizados com o pool $+\mathrm{LigAc}+\mathrm{Al}(\mathrm{OH})_{3}$ que sobreviveram ao desafio foram positivos para a presença de leptospiras nos rins (Figura 14 parte II, lâmina G), enquanto na lâmina H (Figura 14 parte II) há um exemplo de um corte renal positivo de animal imunizado com pool + LigAc + FliC $i$ para a presença de leptospira e, nas lâminas O e P (Figura 14 parte IV) são mostrados corte renais sem leptospiras do mesmo grupo.

Estes dados sugerem que a maioria dos animais imunizados com as preparações vacinais contendo FliC $i$ ficaram protegidos da colonização renal. Altas taxas de sobrevivência e menor porcentagem do estado de portador renal somente ocorreram nos grupos imunizados com LigAc na presença do pool de proteínas recombinantes e FliCi. 
Tabela 8 - Cultura do macerado do rim dos animais sobreviventes ao desafio com L. interrogans sorovar Copenhageni.

\begin{tabular}{|c|c|c|}
\hline \multirow[t]{2}{*}{ Grupos } & $1^{o}, 2^{o}$ e $3^{o}$ Ensaio & $\%$ de Culturas Negativas \\
\hline & Sobreviventes / Total & em relação aos sobreviventes \\
\hline 01- Controle do inóculo & $00 / 30$ & - \\
\hline $02-\mathrm{PBS}+\mathrm{Al}(\mathrm{OH})_{3}$ & $03 / 30$ & 0 \\
\hline 03- PBS + FliC $i$ & $03 / 30$ & 0 \\
\hline 04- Vacina comercial & $29 / 30$ & $93 \%$ \\
\hline 05- Bacterina $+\mathrm{Al}(\mathrm{OH})_{3}$ & $27 / 30$ & $100 \%$ \\
\hline 06- Bacterina + FliC $i$ & $30 / 30$ & $100 \%$ \\
\hline $07-\operatorname{Lig} \mathrm{Ac}+\mathrm{Al}(\mathrm{OH})_{3}$ & $30 / 30$ & 0 \\
\hline 08- LigAc + FliC $i$ & $28 / 30$ & $7 \%$ \\
\hline $09-$ Pool $+\mathrm{Al}(\mathrm{OH})_{3}$ & $15 / 30$ & $27 \%$ \\
\hline 10- Pool + FliCi & $01 / 30$ & $100 \%$ \\
\hline $11-\mathrm{Pool}+\mathrm{LigAc}+\mathrm{Al}(\mathrm{OH})_{3}$ & $26 / 30$ & 0 \\
\hline 12- Pool + LigAc + FliC $i$ & $25 / 29$ & $72 \%$ \\
\hline
\end{tabular}



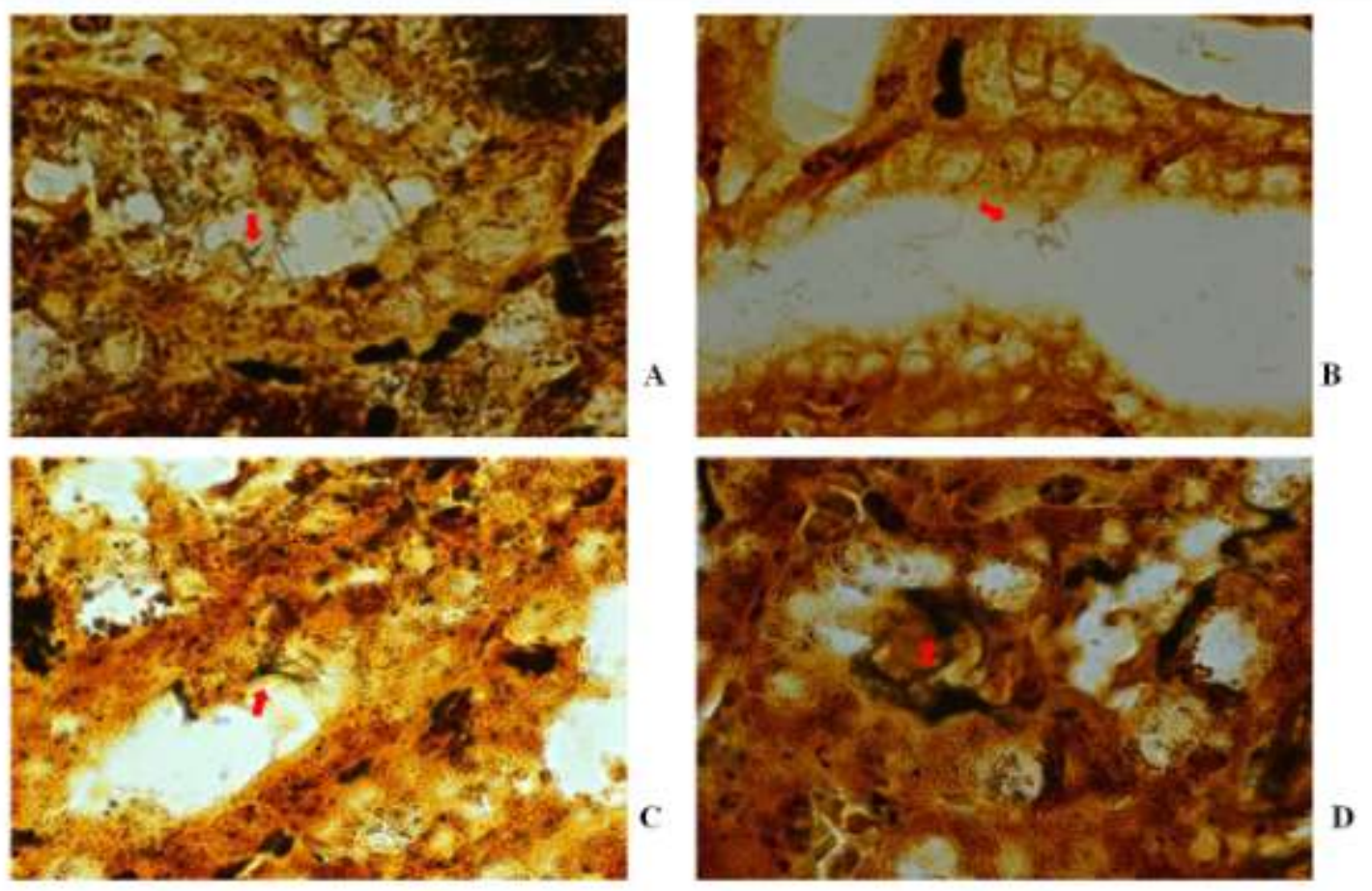

Figura 14 (parte I): Lâminas histológicas coradas pela prata de cortes dos rins dos animais sobreviventes ao desafio. A) $\left.\mathrm{PBS}+\mathrm{Al}(\mathrm{OH})_{3} ; \mathbf{B}\right) \mathrm{PBS}+\mathrm{FliC} i$; $\left.\mathbf{C}\right) \mathrm{LigAc}+$ $\mathrm{Al}(\mathrm{OH})_{3}$; D) $\mathrm{LigAc}+\mathrm{FliC} i$; As setas em vermelho indicam a presença de leptospiras. Aumento de 100X.
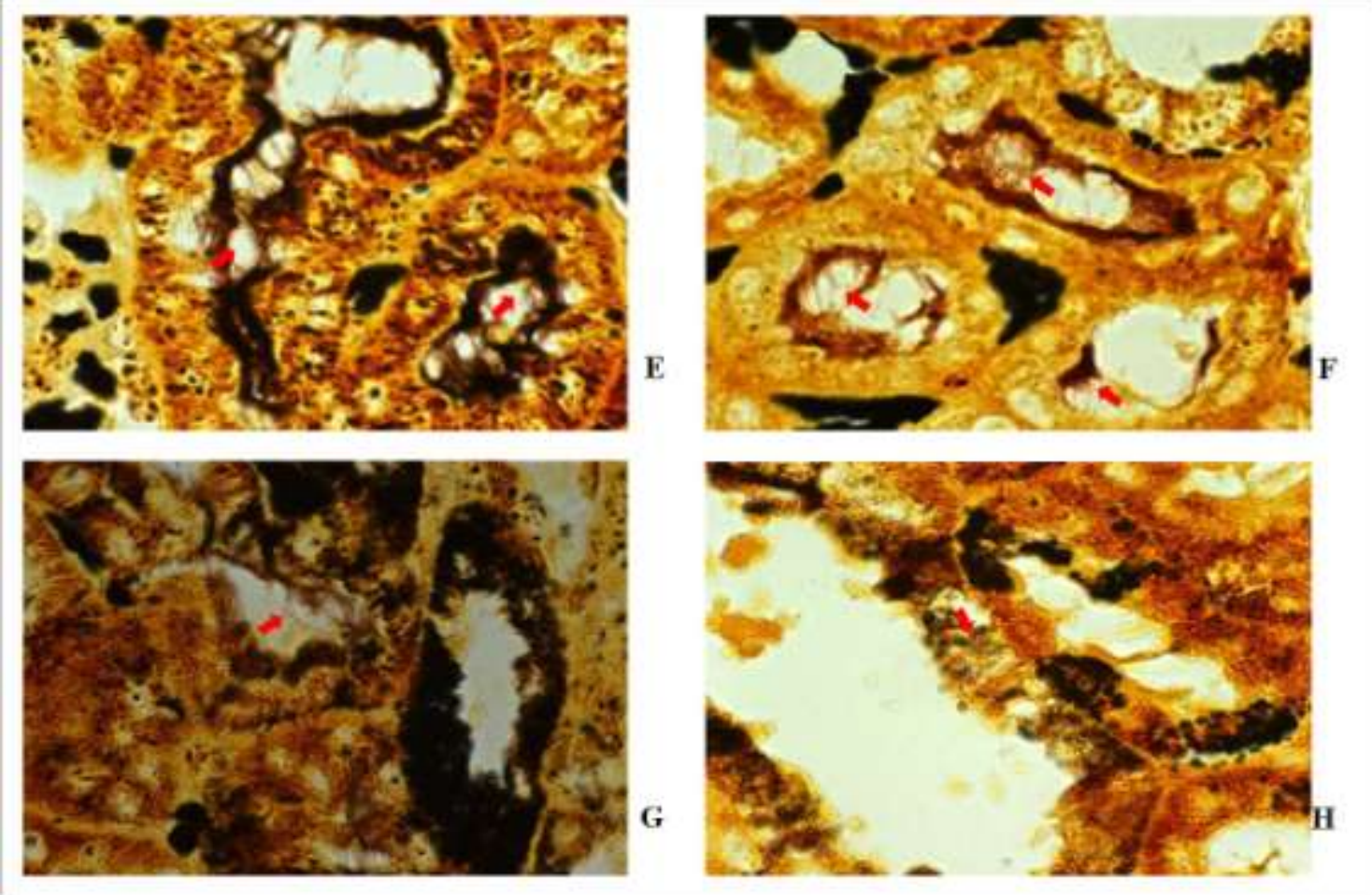

Figura 14 (Parte II): Lâminas histológicas coradas pela prata de cortes dos rins dos animais sobreviventes ao desafio. E) Pool $+\mathrm{Al}(\mathrm{OH})_{3}$; F) Pool $+\mathrm{FliC} i$; G) Pool + $\mathrm{LigAc}$ $\left.+\mathrm{Al}(\mathrm{OH})_{3} ; \mathbf{H}\right) \mathrm{Pool}+\mathrm{LigAc}+\mathrm{FliC}$. As setas em vermelho indicam a presença de leptospiras. Aumento de 100X. 

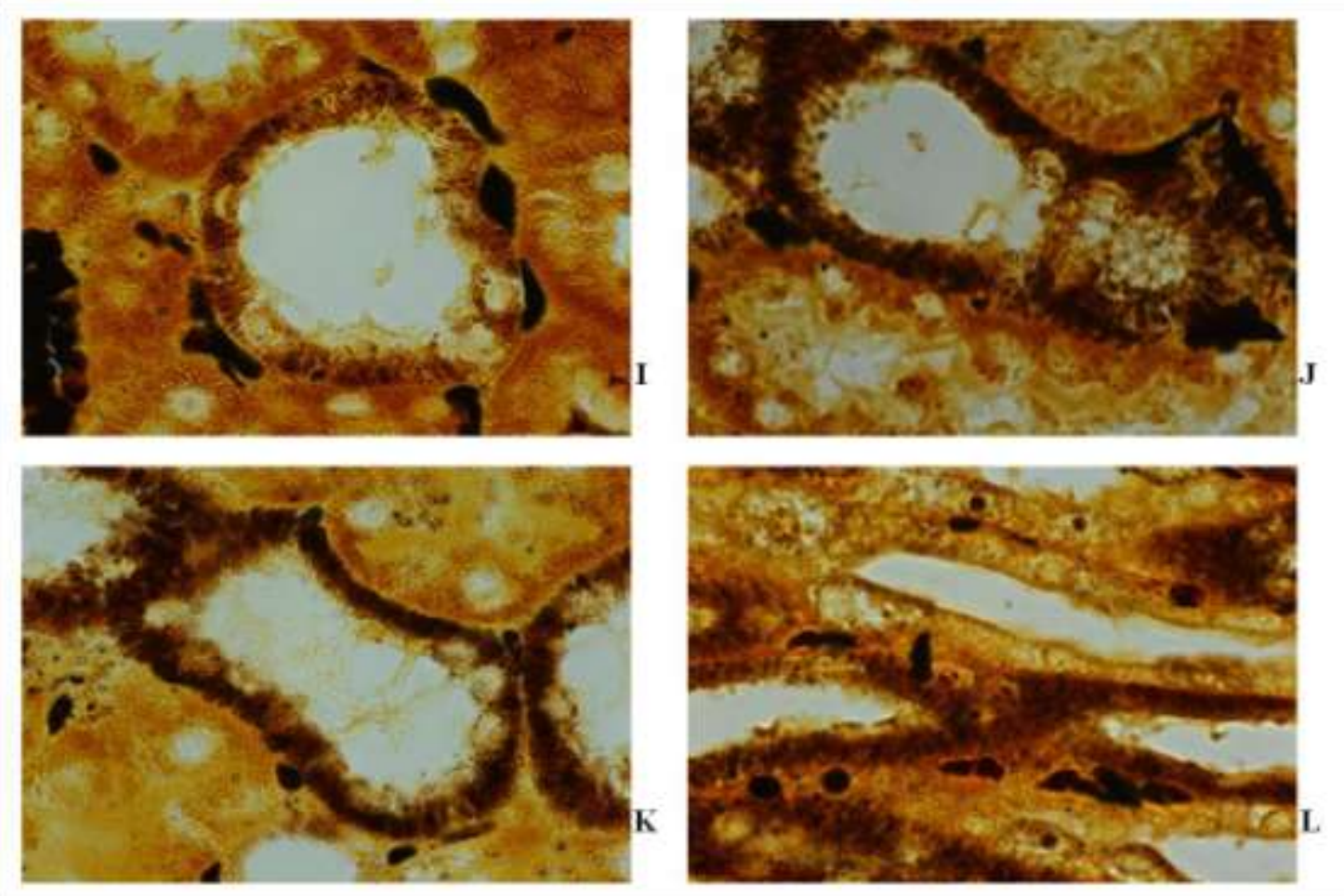

Figura 14 (parte III): Lâminas histológicas coradas pela prata de cortes dos rins dos animais sobreviventes ao desafio. $\mathbf{I} / \mathbf{J})$ Vacina comercial; K/L) Bacterina $+\mathrm{Al}(\mathrm{OH})_{3}$. Aumento de 100X.
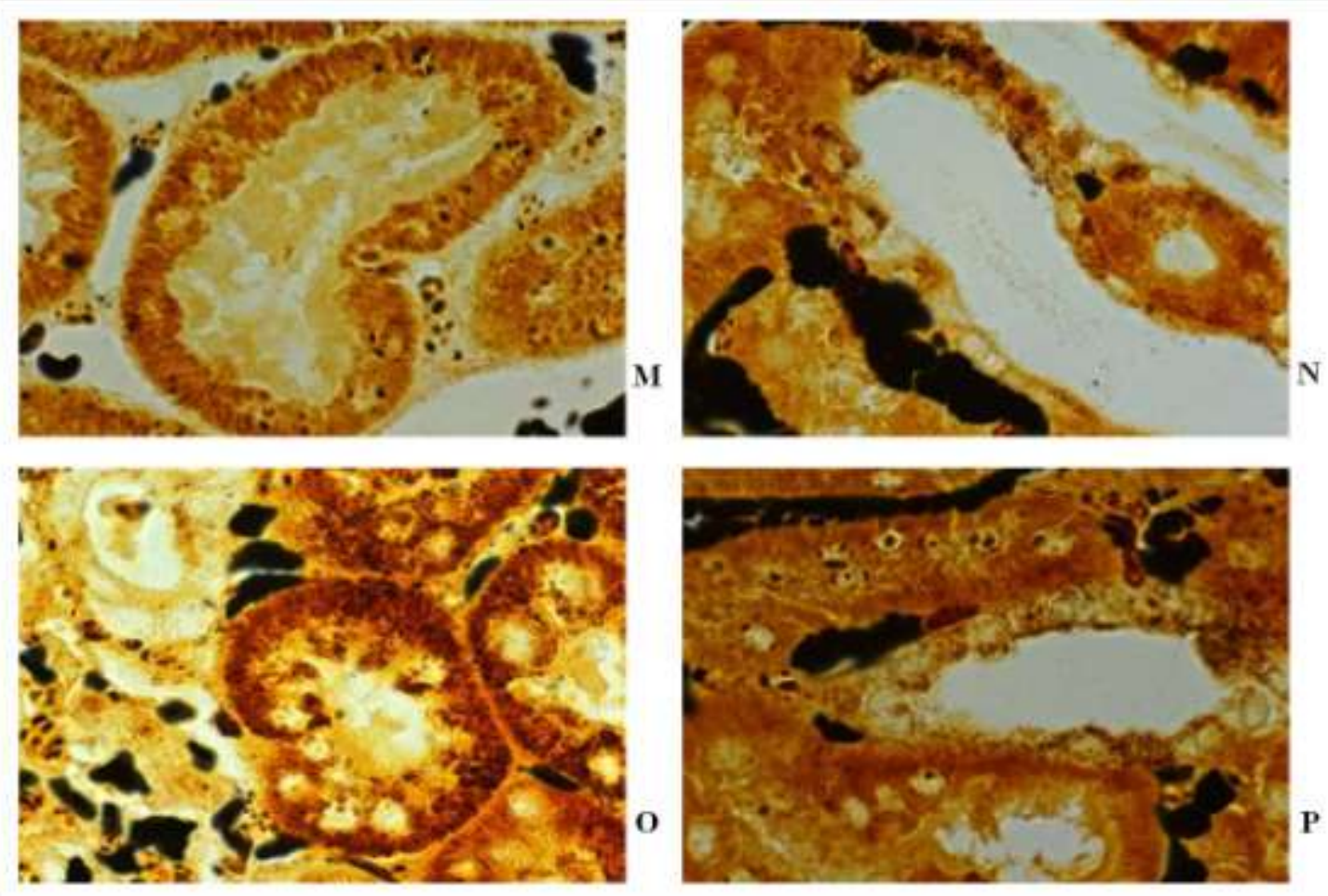

Figura 14 (parte IV): Lâminas histológicas coradas pela prata de cortes dos rins dos animais sobreviventes ao desafio. M/N) Bacterina + FliC $i$; O/P) Pool + LigAc + FliC $i$. Aumento de 100X. 


\subsection{Soroaglutinação Microscópica (SAM)}

O teste de soroaglutinação microscópica foi realizado utilizando-se como antígeno uma cultura de L. interrogans sorovar Copenhageni estirpe L1-130 e os soros da primeira e segunda sangrias numa diluição final de 1:100. Na figura 15, são observados exemplos de um teste de SAM positivo com aglutinação (A) e outro negativo (B). Os resultados do teste de SAM com os soros das primeiras sangrias revelaram que em nenhum caso houve aglutinação de leptospiras. No caso da segunda sangria somente os soros dos animais imunizados com a vacina comercial, bacterina $+\mathrm{Al}(\mathrm{OH})_{3}$, bacterina $+\mathrm{FliC} i$ apresentaram aglutinação, conforme descrito na tabela 9. Posteriormente, estes soros foram titulados em uma série de diluições geométricas de razão dois, sendo a diluição inicial 1/50, utilizando como antígenos 22 sorovares de espécies patogênicas (Australis, Bratislava, Autumnalis, Butembo, Castellonis, Bataviae, Canicola, Whitcombi, Cynopteri, Grippotyphosa, Hebdomadis, Copenhageni, Icterohaemorrhagiae, Javanica, Panama, Pomona, Pyrogenes, Hardjo, Wolffi, Shermani, Tarassovi, Sentot) e dois sorovares de leptospiras não patogênicas (Andamana e Patoc.). O título foi considerado a maior diluição que apresentou 50\% de leptospiras aglutinadas (SOTO, 2006; RODRIGUES, 2008). Na tabela 10, são mostrados os resultados da titulação pelo teste de SAM. Das 24 culturas testadas somente as leptospiras da espécie L.interrogans sorovar Copenhageni estirpes 10A e L1-130 aglutinaram com títulos 1:50 e 1:100.

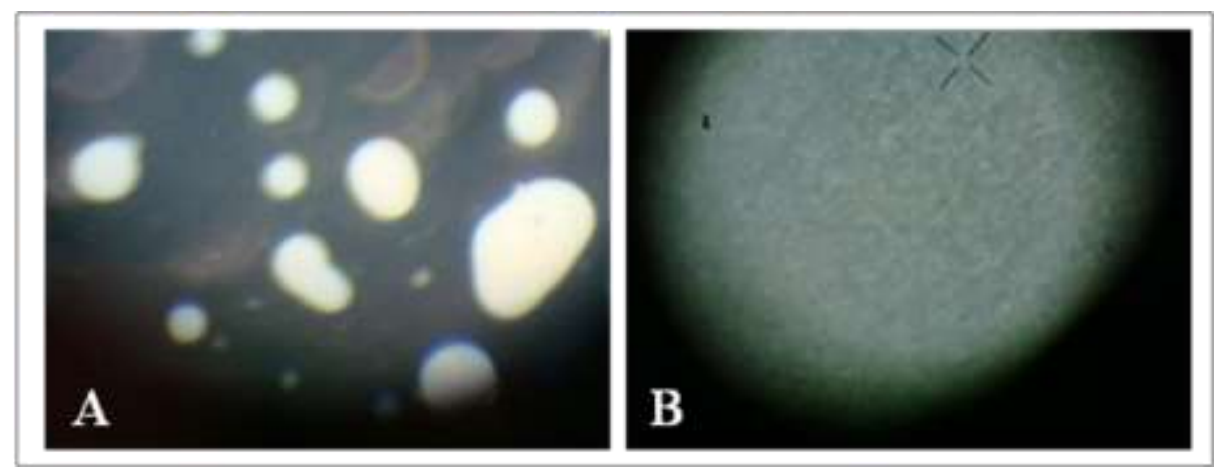

Figura 15: Teste de soroaglutinação microscópica (SAM), leitura em microscópio de campo escuro, cultura de L. interrogans sorovar Copenhageni estirpe L1-130. A) leptospiras aglutinadas; B) leptospiras não-aglutinadas. 
Tabela 9 - Resultado do teste de aglutinação microscópica utilizando soros da segunda sangria de hamsters imunizados nos diferentes grupos e cultura de L. interrogans Copenhageni estirpe L1-130.

\begin{tabular}{|c|c|c|c|}
\hline \multirow{2}{*}{ Grupos } & \multicolumn{3}{|c|}{ Soros dos hamsters } \\
\hline & $1^{o}$ Ensaio & $2^{\circ}$ Ensaio & $3^{o}$ Ensaio \\
\hline 01- Controle do inóculo & $0^{\mathrm{a}}$ & 0 & 0 \\
\hline $02-\mathrm{PBS}+\mathrm{Al}(\mathrm{OH})_{3}$ & 0 & 0 & 0 \\
\hline 03- PBS + FliC $i$ & 0 & 0 & 0 \\
\hline 04- Vacina comercial & $2+$ & $2+$ & $3+$ \\
\hline 05- Bacterina $+\mathrm{Al}(\mathrm{OH})_{3}$ & $2+$ & $2+$ & $2+$ \\
\hline 06- Bacterina + FliC $i$ & $3+$ & $2+$ & $1+$ \\
\hline $07-\operatorname{LigAc}+\mathrm{Al}(\mathrm{OH})_{3}$ & 0 & 0 & 0 \\
\hline 08- LigAc + FliC $i$ & 0 & 0 & 0 \\
\hline 09- Pool $+\mathrm{Al}(\mathrm{OH})_{3}$ & 0 & 0 & 0 \\
\hline 10- Pool + FliC $i$ & 0 & 0 & 0 \\
\hline 11- Pool + LigAc $+\mathrm{Al}(\mathrm{OH})_{3}$ & 0 & 0 & 0 \\
\hline 12- Pool + LigAc + FliC $i$ & 0 & 0 & 0 \\
\hline $\begin{array}{l}\text { a O grau de aglutinação fo } \\
\text { Zoonoses (1985): 0 corresp } \\
50 \%, 3+75 \% \text { e } 4+\text { acima } \\
\text { microscópico. Os soros dos } \\
\text { em solução tamponada de Sör }\end{array}$ & $\begin{array}{l}\text { do segund } \\
\text { ausência d } \\
\text { de leptos } \\
\text { foram dilt }\end{array}$ & $\begin{array}{l}\text { Centro Pan } \\
\text { glutinação, } \\
\text { as aglutina }\end{array}$ & $\begin{array}{r}\text { nericano de } \\
+\quad 25 \%, 2+ \\
\text { no campo } \\
\text { ão de } 1 / 100\end{array}$ \\
\hline
\end{tabular}

Tabela 10: Titulação dos soros da segunda sangria de hamsters imunizados utilizando teste de aglutinação microscópica e culturas de 22 sorovares de leptospiras patogênicas e duas saprófitas.

\begin{tabular}{lccc}
\hline \multirow{2}{*}{ Grupos } & \multicolumn{3}{c}{ Título $^{\mathbf{a}}$} \\
\cline { 2 - 4 } & $\mathbf{1}^{\boldsymbol{o}}$ Ensaio & $\mathbf{2}^{\boldsymbol{o}}$ Ensaio & $\mathbf{3}^{\boldsymbol{o}}$ Ensaio \\
\hline 01- Vacina comercial & $1 / 50$ & $1 / 50$ & $1 / 100$ \\
\hline 02- Bacterina + $\mathrm{Al}(\mathrm{OH})_{3}$ & $1 / 50$ & $1 / 50$ & $1 / 50$ \\
\hline 03- Bacterina + FliC $i$ & $1 / 100$ & $1 / 50$ & $1 / 50$
\end{tabular}

${ }^{\mathrm{a}}$ Os soros foram titulados em uma série de diluições geométricas de razão dois, sendo a diluição inicial 1/50. O título foi considerado a maior diluição que apresentou $50 \%$ de leptospiras aglutinadas. Das 24 culturas testadas somente as leptospiras da espécie L.interrogans sorovar Copenhageni estirpes 10A e L1-130 aglutinaram. 


\subsection{Teste de inibição de crescimento de Leptospiras}

O teste de inibição de crescimento bacteriano, in vitro, foi realizado com os soros da segunda sangria, previamente inativados a $56{ }^{\circ} \mathrm{C}$, durante 30 minutos, e uma cultura de $L$. interrogans sorovar Copenhageni estirpe L1-130. A quantificação de leptospiras nos cultivos foi realizada por ELISA, utilizando o soro de referência anti-L.interrogans Sorovar Copenhageni estirpe $10 \mathrm{~A}$. Os gráficos da figura 16 mostram que houve soroneutralização apenas nas culturas com os soros dos grupos dos animais imunizados com a vacina comercial, bacterina $+\mathrm{Al}(\mathrm{OH})_{3}$, bacterina+FliCi. Não houve diferenças detectáveis pelo ELISA nas diferentes diluições dos soros usadas. Estes resultados foram confirmados qualitativamente através da observação das culturas em microscópio de campo escuro.

Para confirmar o teste de inibição do crescimento feito em placa, paralelamente foi realizado o teste de inibição do crescimento em tubo. Foram considerados positivos para anticorpos neutralizantes aqueles tubos sem crescimento de leptospiras, observados pela turbidez e observação em microscópio de campo escuro. Somente nos tubos contendo as culturas com os soros dos grupos dos animais imunizados com a vacina comercial, bacterina $+\mathrm{Al}(\mathrm{OH})_{3}$, bacterina $+\mathrm{FliC} i$ não foram observados crescimentos (culturas negativas).

Os resultados da inibição do crescimento estão de acordo com os obtidos pela soroaglutinação, pois somente os soros dos animais imunizados com as preparações de culturas de leptospiras (bacterinas) foram capazes de induzir a formação de anticorpos aglutinantes capazes de neutralizar o crescimento bacteriano. 

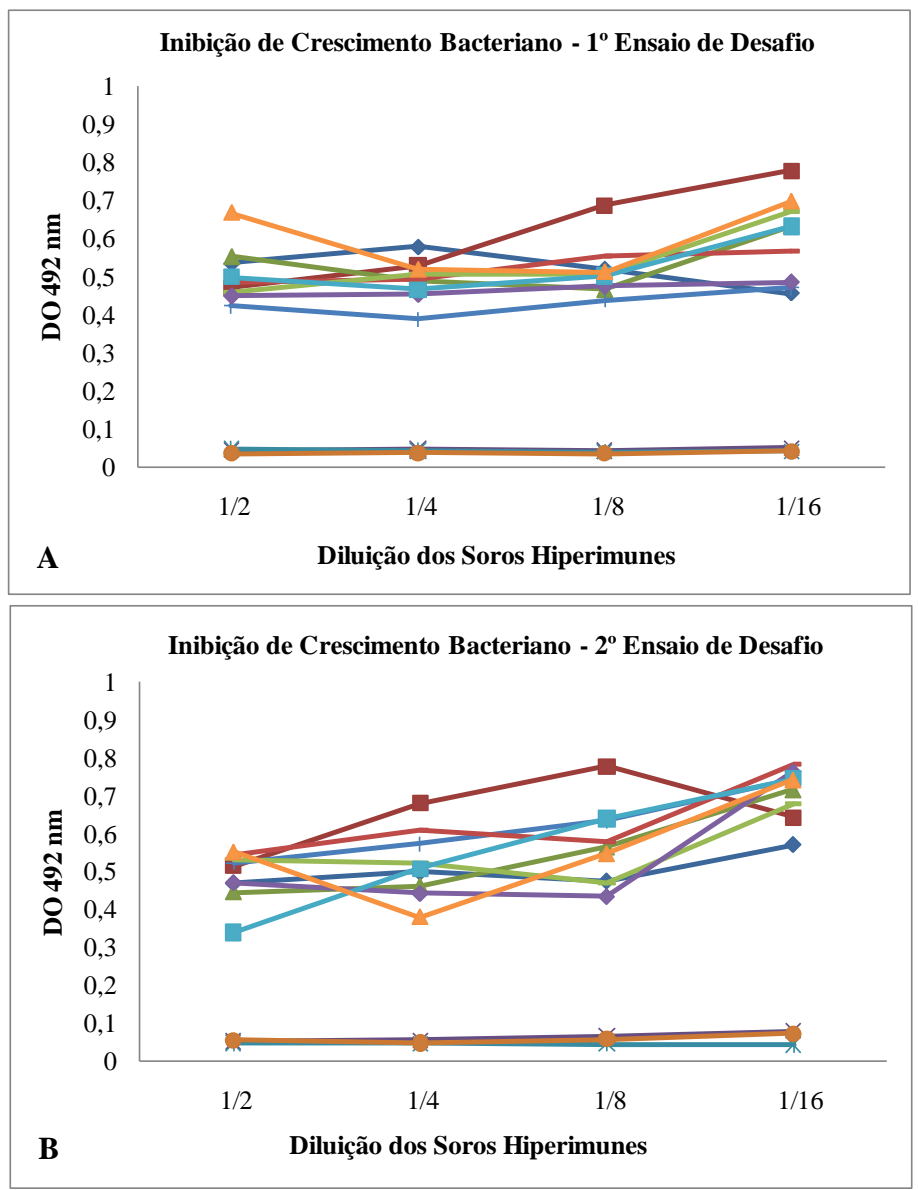

Legenda:

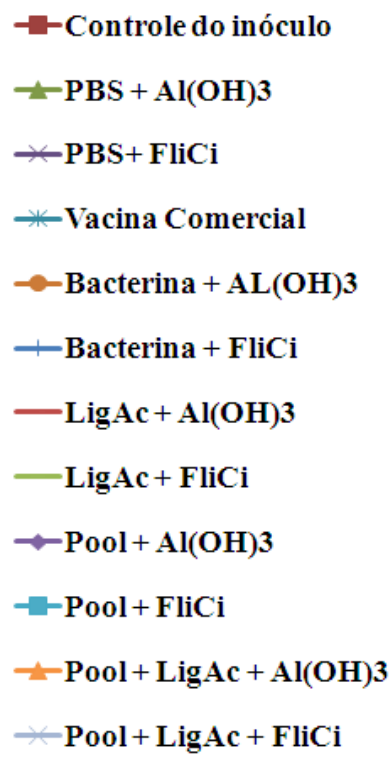

C

Inibição de Crescimento Bacteriano - $3^{\circ}$ Ensaio de Dasafio

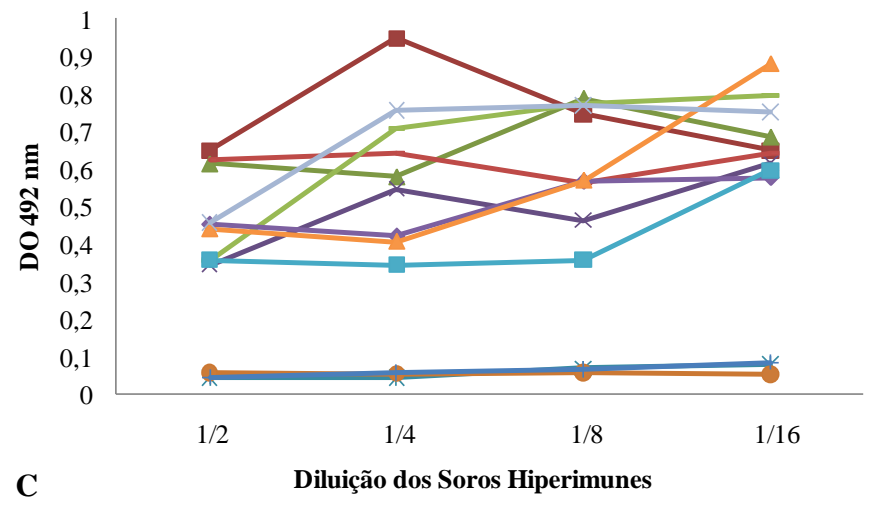

$\because$ Pool + LigAc + FliCi

Figura 16: Teste de inibição de crescimento de Leptospiras. A) soro da segunda sangria do $1^{\circ}$ ensaio de desafio; B) soro da segunda sangria do $2^{\circ}$ ensaio de desafio; C) soro da segunda sangria do $3^{\circ}$ ensaio de desafio. 


\subsection{Análise da expressão dos genes de citocinas de resposta Th1/Th2}

Como não existem reagentes disponíveis para detecção das citocinas por ELISA em hamsters, a análise da expressão relativa dos genes de citocinas INF $\gamma$, IL-12p40 (resposta Th1), IL-4 e IL-10 (resposta Th2), foram realizados por PCR semiquantitativo, utilizando células mononucleares do sangue periférico (PBMC) coletado um dia antes do desafio, em animais do primeiro ensaio. A extração do RNA total das células foi realizada a partir do pool do sangue dos animais. Na figura 17, são mostrados os géis de agarose com os produtos amplificados em cada grupo e na figura 18 estão os gráficos de expressão relativa que foi calculada dividindo-se o valor da densidade óptica obtida de cada banda (INFy, IL4, IL10 e IL12p40) pelo valor do controle endógeno ( $\beta$-actina).

A expressão gênica de INFy está diminuída nas amostras de PBMC de animais imunizados com pool $+\mathrm{AL}(\mathrm{OH})_{3}$ e pool + FliC $i$ (Figuras 17A e 18A; números 9 e 10) quando comparada com a expressão nas amostras de PBMC dos animais dos grupos controle negativos (controle do inóculo, PBS+ $\mathrm{AL}(\mathrm{OH})_{3}$ e PBS + FliCi) (Figuras 17A e 18A, números 1, 2 e 3), enquanto a expressão gênica desta citocina está ligeiramente aumentada nos outros grupos (Figuras 17 A e 18 A, números 4 a 8, 11 e 12). Como se trata de uma análise semiquantitativa de um único ensaio, não podemos avaliar se estes resultados são significativamente diferentes.

Quanto à expressão gênica de IL12p40, é possível observar um aumento de sua expressão nas células dos grupos de animais imunizados com a bacterina acrescida de $\mathrm{Al}(\mathrm{OH})_{3}$ ou FliCi, $\mathrm{LigAc}+\mathrm{Al}(\mathrm{OH})_{3}$, pool $+\mathrm{LigAc}+\mathrm{Al}(\mathrm{OH})_{3}$ (Figuras $17 \mathrm{~B}$ e $18 \mathrm{~B}$, números 5 a 7 e 11). A expressão gênica desta citocina, nas células dos animais imunizados com a vacina comercial está um pouco aumentada (Figuras 17B e 18B número 4), quando comparada com a expressão nas amostras de PBMC dos animais dos grupos controle negativos (controle do inóculo, PBS+ $\mathrm{AL}(\mathrm{OH})_{3}$ e PBS + FliCi) (Figuras 17 B e 18 B, números 1 a 3). O mesmo acontece com as células obtidas dos grupos imunizados com pool+LigA+FliCi (Figuras 17B e 18B; número 12), enquanto nos grupos LigAc+ FliCi; pool $+\mathrm{Al}(\mathrm{OH})_{3}$ e pool + FliCi praticamente não se observa a expressão de IL12p40 (Figuras 17B e 18B, números 8 a 10).

Com relação aos genes de citocinas de resposta Th2 (IL4 e IL10), a expressão de IL10 está diminuída nas amostras de PBMC de animais imunizados com LigAc + FliC $i$, pool $+\mathrm{AL}(\mathrm{OH})_{3}$ e pool + FliCi (Figuras 17C e 18C; números 8 a 10) quando comparada com 
a expressão nas amostras de PBMC dos animais dos grupos controle negativos (controle do inóculo, PBS+ $\mathrm{AL}(\mathrm{OH})_{3}$ e $\mathrm{PBS}+\mathrm{FliCi}$ ) (Figuras 17C e 18C, números 1 a 3), enquanto a expressão gênica desta citocina está aumentada nos outros grupos (Figuras 17C e 18C, números 4 a 7, 11 e 12). Não observamos expressão gênica de IL-4 em nenhum grupo analisado (Figuras 17D e 18D).

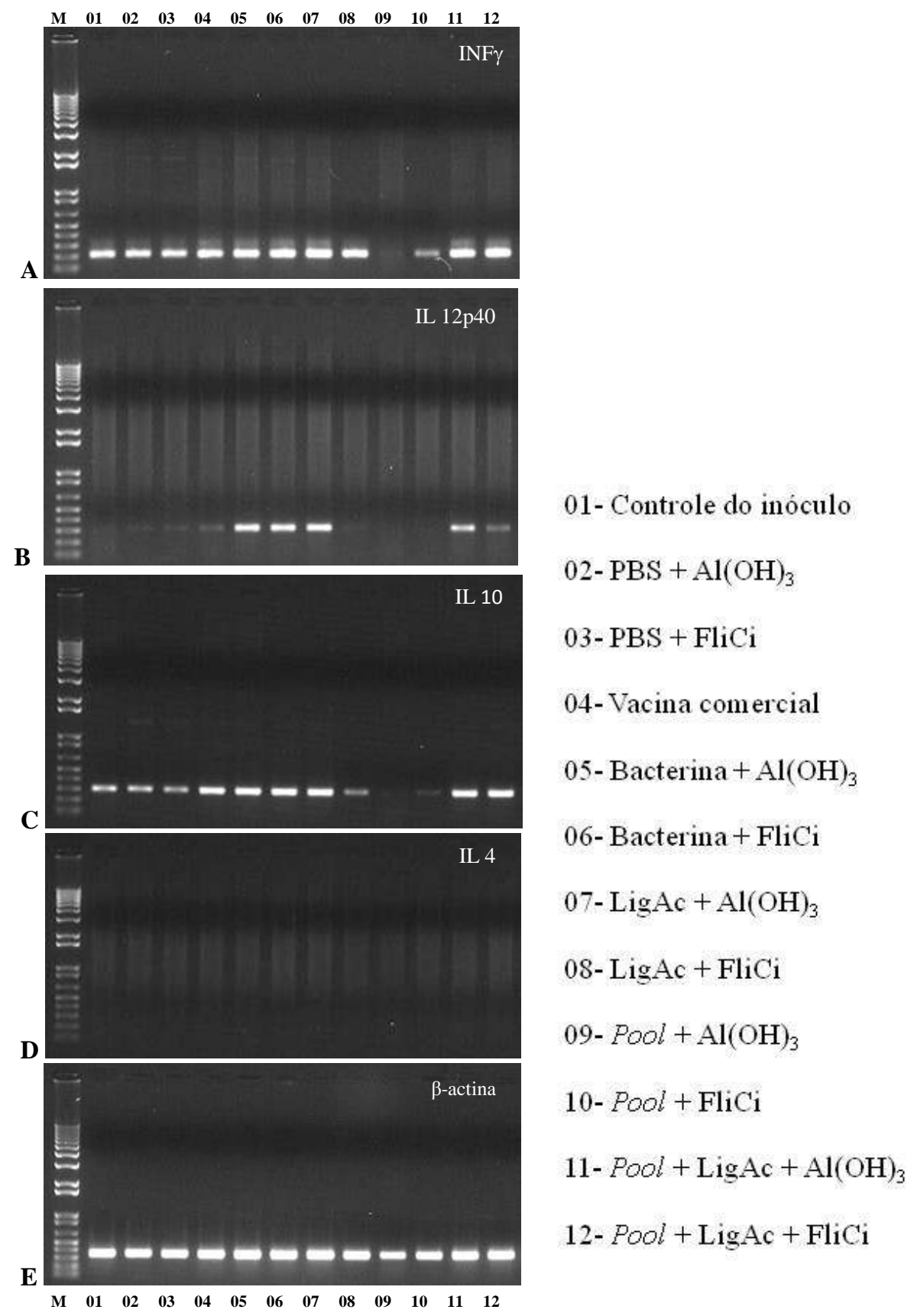

Figura 17: Produtos amplificados por PCR, análise da expressão de citocinas, gel de agarose $1 \%$ corado com brometo de etídio. A) INFy; B) IL12p40 C) IL10; D) IL4; E) Controle endógeno: $\beta$-actina. $\mathbf{M}$ - Peso molecular $1 \mathrm{~Kb}$ plus DNA Ladder (Invitrogen ${ }^{\mathrm{TM}}$ ). 

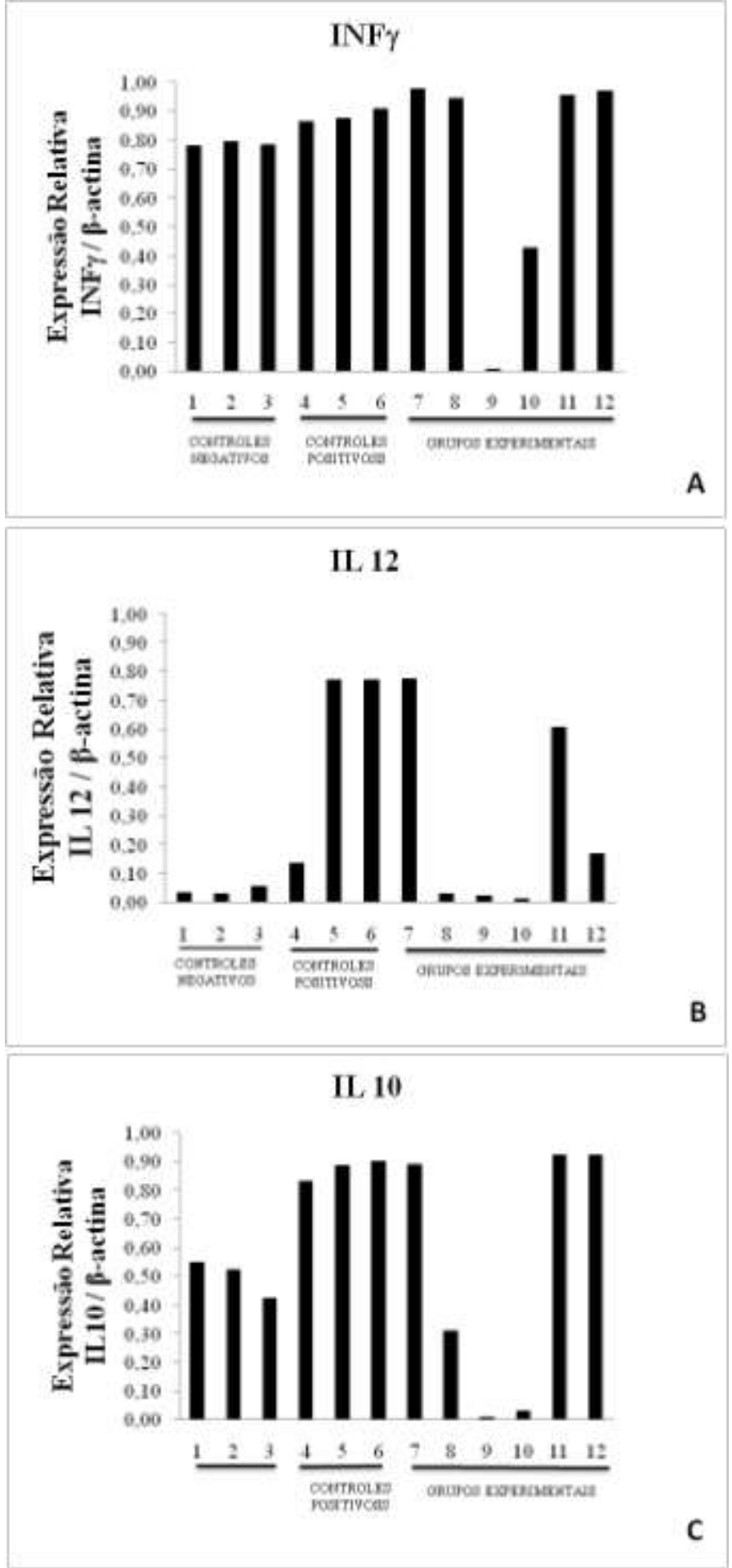

01- Controle do inóculo

02- $\mathrm{PBS}+\mathrm{Al}(\mathrm{OH})_{3}$

03-PBS + FliCi

04-Vacina comercial

$05-$ Bacterina $+\mathrm{Al}(\mathrm{OH})_{3}$

06- Bacterina + FliCi

$07-\mathrm{LigAc}+\mathrm{Al}(\mathrm{OH})_{3}$

08- LigAc + FliCi

$09-$ Pool $+\mathrm{Al}(\mathrm{OH})_{3}$

10- Pool + FliCi

11- Pool $+\mathrm{LigAc}+\mathrm{Al}(\mathrm{OH})_{3}$

12- Pool + LigAc + FliCi

Figura 18: Densitometria dos produtos de PCR. Comparação da expressão de citocinas em relação ao controle endógeno ( $\beta$-actina). A) INF $\gamma$; B) IL12p40; C) IL10. 
Para confirmar os resultados de expressão relativa dos genes de citocinas obtidos por PCR semiquantitativo, foi realizado experimento por transcrição reversa do mRNA seguida de PCR em tempo real (RT-qPCR), utilizando o RNA total extraído de células mononucleares do sangue periférico dos animais no mesmo ensaio.

Com relação aos genes de citocinas de resposta Th1 (INFy e IL-12), os gráficos da figura 19 mostram expressão gênica de INFy está diminuída, nas amostras de PBMC de animais imunizados com pool $+\mathrm{AL}(\mathrm{OH})_{3}$ e pool $+\mathrm{FliC} i$, quando comparada com a expressão nas amostras de PBMC dos animais dos grupos controle negativos (controle do inóculo, $\mathrm{PBS}+\mathrm{AL}(\mathrm{OH})_{3}$ ), enquanto a expressão gênica desta citocina está ligeiramente aumentada nos outros grupos com exceção dos grupos bacterina $+\mathrm{FliC} i$ e pool $+\mathrm{LigA}+$ FliCi. De maneira geral, estes dados estão de acordo com o PCR semiquantitativo com exceção do grupo PBS + FliCi, em que a expressão gênica de INFy está aumentada em relação aos outros grupos controle-negativos e os grupos bacterina $+\mathrm{FliC} i$ e pool + LigA + FliC $i$, cuja expressão de INF $\gamma$ está diminuída em relação ao controle do inóculo. Não observamos expressão gênica em níveis adequados de IL-4 para análise da expressão relativa em nenhum grupo analisado.

Com relação aos genes de citocinas de resposta Th2 (IL4 e IL10), a expressão de IL10 está diminuída nas amostras de PBMC de animais imunizados com pool $+\mathrm{AL}(\mathrm{OH})_{3}$ e pool + FliC $i$ quando comparada com a expressão nas amostras de PBMC dos animais dos grupos controle negativos (controle do inóculo, $\mathrm{PBS}+\mathrm{AL}(\mathrm{OH})_{3}$, enquanto a expressão gênica desta citocina está aumentada nos outros grupos. Estes resultados estão de acordo com o PCR semiquantitativo com exceção do grupos imunizado com PBS + FliCi em que a expressão gênica de IL10 está aumentada em relação aos outros grupos controles-negativos. Não observamos expressão gênica de IL-12 em nenhum grupo analisado. 

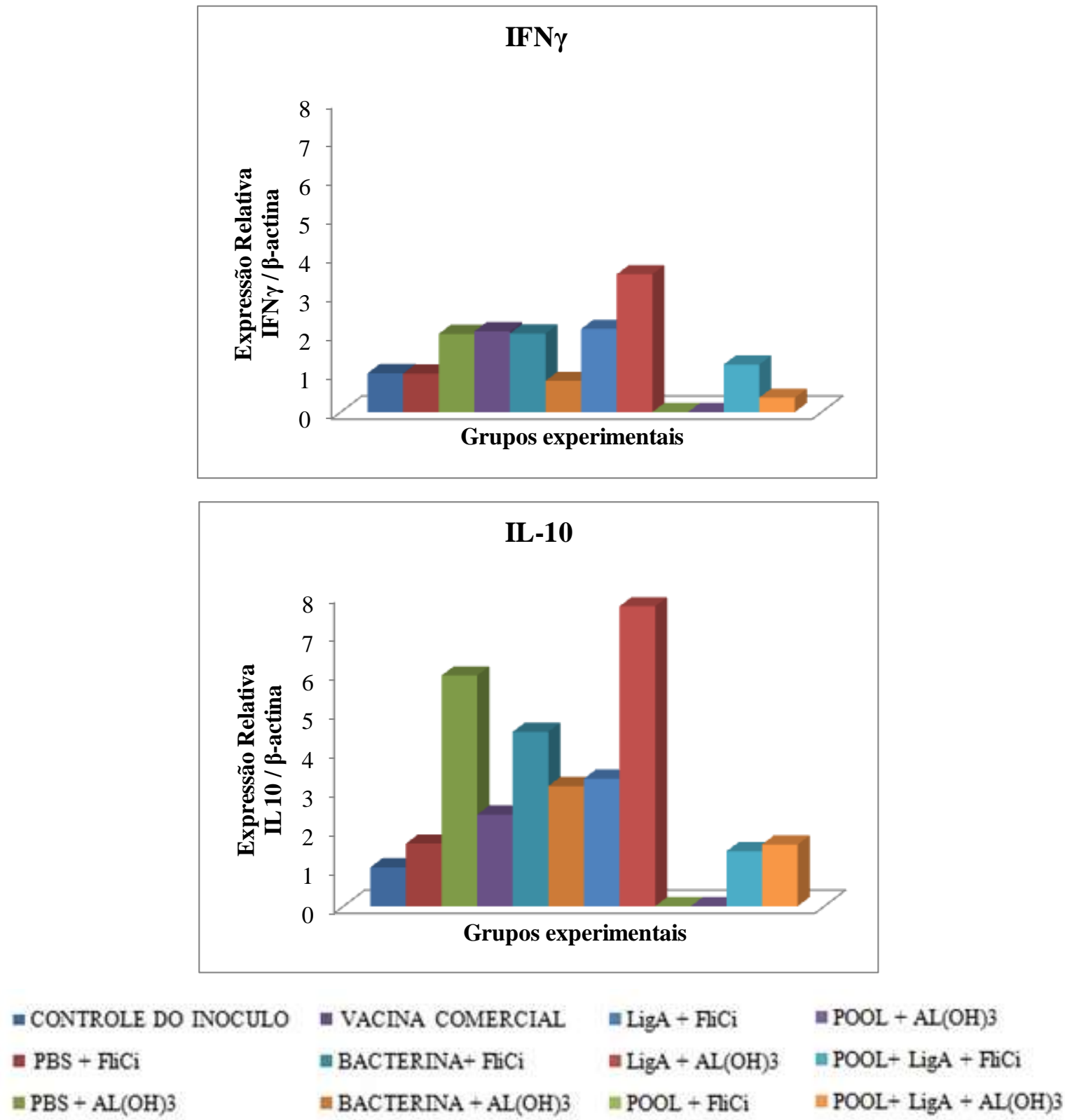

Figura 19: Expressão relativa de citocinas INF $\gamma$; e IL-10em relação ao controle endógeno ( $\beta$-actina) por RT-PCR em tempo real. 
4.10 Comparação dos dados de sobrevivência, estado de portador renal e expressão dos genes de citocinas de resposta Th1 e Th2

A comparação entre os parâmetros sobrevivência, estado de portador renal e expressão relativa dos genes de citocinas, obtidos por PCR semiquantitativo está representada na tabela 11. É possível observar uma correlação positiva entre o aumento da expressão dos mRNA dos genes de citocinas de resposta Th1 e Th2 e sobrevivência. Principalmente, em relação aos genes da citocinas IL-12 e IL-10. De maneira inversa, há correlação entre colonização renal estimada pela cultura positiva de leptospiras e diminuição da expressão dos genes das citocinas IFN $\gamma$ e IL12p40.

Tabela 11 - Comparação entre os animais sobreviventes em relação à colonização renal e expressão relativa dos genes de citocinas obtidos por PCR.

\begin{tabular}{|c|c|c|c|c|c|}
\hline \multirow{3}{*}{ Grupos } & \multirow{3}{*}{ Sobreviventes } & \multirow{3}{*}{$\begin{array}{l}\text { Culturas } \\
\text { negativas }\end{array}$} & \multicolumn{3}{|c|}{ Expressão Relativa } \\
\hline & & & \multicolumn{2}{|c|}{ Th1 } & \multirow{2}{*}{$\begin{array}{c}\text { Th2 } \\
\text { IL-10 }\end{array}$} \\
\hline & & & $\mathrm{INF} \gamma$ & IL-12 & \\
\hline 01- Controle do inóculo & $0 \%$ & - & - & - & - \\
\hline $02-\mathrm{PBS}+\mathrm{Al}(\mathrm{OH})_{3}$ & $10 \%$ & 0 & - & - & - \\
\hline 03- PBS + FliC $i$ & $10 \%$ & 0 & - & - & - \\
\hline 04- Vacina comercial & $97 \%$ & $93 \%$ & $\uparrow$ & $\uparrow$ & $\uparrow$ \\
\hline 05- Bacterina $+\mathrm{Al}(\mathrm{OH})_{3}$ & $90 \%$ & $100 \%$ & $\uparrow$ & $\uparrow$ & $\uparrow$ \\
\hline 06- Bacterina + FliC $i$ & $100 \%$ & $100 \%$ & $\uparrow$ & $\uparrow$ & $\uparrow$ \\
\hline $07-\mathrm{LigAc}+\mathrm{Al}(\mathrm{OH})_{3}$ & $100 \%$ & 0 & $\uparrow$ & $\bar{\uparrow}$ & $\uparrow$ \\
\hline 08- LigAc + FliC $i$ & $93 \%$ & $7 \%$ & $\uparrow$ & $\downarrow$ & $\downarrow$ \\
\hline $09-$ Pool $+\mathrm{Al}(\mathrm{OH})_{3}$ & $50 \%$ & $27 \%$ & $\downarrow$ & $\downarrow$ & $\downarrow$ \\
\hline 10- Pool + FliCi & $3 \%$ & $100 \%$ & $\downarrow$ & $\downarrow$ & $\downarrow$ \\
\hline $11-\mathrm{Pool}+\mathrm{LigAc}+\mathrm{Al}(\mathrm{OH})_{3}$ & $87 \%$ & 0 & $\uparrow$ & $\uparrow$ & $\uparrow$ \\
\hline 12- Pool + LigAc + FliCi & $86 \%$ & $72 \%$ & $\uparrow$ & $\bar{\uparrow}$ & $\uparrow$ \\
\hline
\end{tabular}




\section{DISCUSSÃO}

As vacinas constituem a estratégia disponível mais efetiva na prevenção e controle de doenças infecciosas. A erradicação da varíola, a diminuição dos casos de tétano, difteria e coqueluche e a erradicação da poliomielite nas Américas são exemplos da eficiência da vacinação. A Organização Mundial de Saúde estima que três milhões de mortes sejam evitadas, anualmente, com os programas de vacinação existentes em todo mundo. Entretanto, o desenvolvimento de novas vacinas representa uma prioridade mundial, pois ainda não existem vacinas para muitas doenças, principalmente para aquelas que afetam pessoas residentes de zonas rurais ou favelas urbanas de países em desenvolvimento, como leishmaniose, doença do sono, malária, doença de Chagas, leptospirose, entre outras, que geram um impacto devastador sobre a humanidade. Há um grande volume de trabalhos científicos que tratam da biologia, imunologia e genética dos parasitas causadores destas doenças, porém apesar de todo esse conhecimento não há ferramentas profiláticas disponíveis (HOTEZ e FERRIS, 2006).

A leptospirose é uma das principais zoonoses do mundo. No Brasil, é considerada um problema de saúde pública, o número de casos aumenta principalmente no verão em decorrência de chuvas e alagamentos de áreas urbanas. De acordo com dados da Secretaria de Vigilância em Saúde do Ministério da Saúde, entre janeiro a outubro de 2005, foram confirmados 2.307 casos de leptospirose em humanos, com 260 óbitos. Somente em Santa Catarina, após as enchentes de 2008, o total de casos chegou a 394, com 19 óbitos.

O controle da doença envolve medidas difíceis de serem adotadas, o que tem contribuído para o aumento da incidência da leptospirose. Algumas vacinas estão sendo usadas, porém promovem proteção apenas contra os sorovares presentes na preparação e falham em induzir imunidade de longa duração.

Os resultados apresentados nesta dissertação demonstram que o desenvolvimento de novas formulações vacinais contra a leptospirose, utilizando formas recombinantes purificadas de proteínas de superfície como antígenos e a flagelina FliCi como adjuvante, é um caminho promissor.

As seis prováveis lipoproteínas de membrana externa utilizadas neste trabalho, como modelo de antígeno, foram selecionadas através de análise in silico a partir do banco de dados de lipoproteínas de L. interrogans sorovar Copenhageni construído por Setubal et al. (2006). O programa PSORT (http://psort.ims.u-tokyo.ac.jp/form.html) foi utilizado para predizer a 
localização celular destas lipoproteínas na bactéria. Nesta análise, das 136 prováveis lipoproteínas do banco, 48 foram identificadas como possíveis proteínas de membrana externa com probabilidade igual ou superior a 70\% (BARBOSA et al., 2010). E, para adequada expressão em $E$. coli, dois outros critérios foram subsequentemente adotados, são eles: a presença de no máximo quatro resíduos de cisteínas e a massa molecular da sequência madura da proteína ser igual ou inferior a $40 \mathrm{kDa}$. Das 48 prováveis lipoproteínas de membrana externa, 28 foram selecionadas utilizando estes dois critérios. Destas 28 sequências, 6 foram escolhidas para este trabalho por serem proteínas novas, sem função conhecida e serem adequadamente expressas em E. coli.

A expressão de lipoproteínas maduras (sem peptídio sinal) em E. coli frequentemente leva à formação de corpúsculos de inclusão (HAAKE et al., 1999; GAMBERINI et al., 2005). As proteínas presentes nestes corpúsculos estão desnaturadas implicando na solubilização da proteína recombinante. Este procedimento pode envolver a utilização de agentes desnaturantes e agentes redutores. Consequentemente podem resultar em problemas com a correta renaturação da proteína (SORENSEN e MORTENSEN, 2005). Por outro lado, a expressão heteróloga de lipoproteínas em E. coli com peptídeo sinal nativo pode resultar na expressão da proteína recombinante com lipidação incompleta ou ausente, provavelmente porque a peptidase sinal de E.coli não reconhece apropriadamente o lipobox de outras bactérias filogeneticamente distantes, como a Leptospira (SETUBAL et al., 2006)

Os espectros de dicró́smo circular realizados com as proteínas purificadas e as análises feitas por gel SDS-PAGE mostraram que os protocolos de purificação estabelecidos foram adequados para a obtenção das proteínas com rendimento e pureza suficientes e mantiveram a conformação estrutural das proteínas recombinantes.

A localização das proteínas na membrana externa foi experimentalmente confirmada, por nosso grupo, para a proteína Lp22 (LIC10507) (GÓMEZ et al., 2008) e para Lp35 (LIC10009 - dados não publicados). Além disso, Lp22 é capaz de aumentar a expressão de moléculas de adesão (ICAM-1 e E-selectina) em células endoteliais (HUVECS). As moléculas de adesão são proteínas localizadas na superfície de células eucarióticas e estão envolvidas nas interações celulares ou com a matriz extracelular. Muitas bactérias, como a leptospira, invadem os tecidos do hospedeiro através de sua habilidade em ligarem-se às moléculas de adesão. Estes dados sugerem que Lp22 deve participar diretamente destes mecanismos (GÓMEZ et al., 2008).

A outra proteína escolhida como antígeno vacinal para este trabalho foi a LigA que pertence a uma família de proteínas bacterianas que contém domínios repetidos Big (bacterial 
immunoglobulin-like). Vários grupos mostraram que esta proteína é capaz de induzir proteção contra leptospirose, mas não confere imunidade esterelizante (KOIZUMI e WATANABE, 2004; PALANIAPPAN; RAMANUJAM; CHANG, 2007; SILVA et al., 2007; FAISAL et al., 2008; YAN et al., 2008). Neste trabalho, os animais imunizados com as diferentes formulações vacinais contendo LigAc apresentaram altos títulos de anticorpos e foram protegidos contra o desafio letal, mas não da colonização dos rins. Nos grupos imunizados com $\operatorname{LigAc}+$ FliCi apenas 2 animais em 28 não apresentaram culturas positivas. Entretanto, nos animais imunizados com $\mathrm{Pool}+\mathrm{LigAc}+\mathrm{FliC} i$ observou-se maior redução no números de culturas positivas (28\%) com títulos contra a proteína LigAc muito superiores ( 1:100.000). A combinação das seis lipoproteínas recombinantes pode ter produzido um efeito sinergístico sobre a resposta imunoprotetora. Estas proteínas quando administradas sozinhas com alumínio apresentaram baixa eficácia (50\% de proteção e $73 \%$ de culturas positivas) e com FliCi não são capazes de induzir proteção contra o desafio letal, apesar dos soros dos animais apresentarem altos títulos de anticorpos. O efeito sinergístico já foi verificado por outros grupos, como a OmpL1 e a lipoproteína LipL41 que somente co-administradas, foram capazes de conferir proteção em hamsters contra o desafio com leptospiras patogênicas (HAAKE et al., 1999) e três proteínas de membrana de L.interrogans sorovar Pomona recombinantes (rLp1454, rLp1118 e rMceII) apresentaram maior eficiência em termos de proteção e menores danos renais quando administradas em conjunto (CHANG et al., 2007).

Os mecanismos imunoprotetores contra a leptospirose ainda não estão esclarecidos. Vallan-Pauillac e Merien (2006) demonstraram que leptospiras patogênicas estimulam in vivo a produção citocinas de resposta Th1 e Th2 em hamsters. Nossos resultados, apesar de preliminares, sugerem um aumento da expressão dos genes das citocinas de resposta Th1 e Th2 nos grupos que foram protegidos do desafio letal e uma redução da expressão nos grupos onde ocorreu morte e maior número de culturas positivas. Estes resultados estão de acordo com vários estudos publicados. Animais imunizados com LigA como vacina de DNA foram protegidos contra desafio letal de leptospira, apresentaram uma redução nas lesões renais e indução da expressão de citocinas de resposta Th1 (IL12 e INF- $\gamma$ ) e Th2 (IL10 e IL4) (FAISAL et al., 2008). Da mesma maneira, três proteínas recombinantes (Lp0607, Lp118 e Lp1554) de membrana externa de Leptospira foram capazes de induzir proteção parcial, diminuição do número de animais portadores renais e estimular a expressão de citocinas de resposta Th1 (INF- $\gamma$ ) e Th2 (IL10 e IL4) (FAISAL et al., 2009).

Em conjunto, os resultados apresentados nesta dissertação sugerem que uma vacina multivalente contra leptospirose, composta pela proteína LigAc e seis proteínas 
recombinantes de membrana externa de Leptospira, acrescida de flagelina FliC $i$ como adjuvante, seja capaz de induzir mecanismos imunológicos (humoral e celular) envolvidos na proteção e colonização dos órgãos-alvo.

Flagelinas de Salmonella têm revelado um grande potencial para utilização como adjuvantes vacinais de administração por via parenteral ou de mucosa. Até o momento, nenhum estudo avaliou o efeito adjuvante de flagelinas frente a proteínas de Leptospira. Este estudo, portanto, é inédito e de grande potencial aplicado. 


\section{CONCLUSÕES}

- Os espectros de dicroísmo circular realizados, com as proteínas purificadas e as análises feitas por gel SDS-PAGE, mostraram que os protocolos de purificação estabelecidos foram adequados, para a obtenção das proteínas com bom rendimento, bandas majoritárias sem contaminantes e conformação estrutural das proteínas recombinantes preservada.

- As análises de dicroísmo circular também demonstraram a presença de estruturas $\alpha$-hélice e randômica nas proteínas recombinantes Lp25, Lp11, Lp21, Lp22 e LigAc, e uma predominância de estrutura randômica e folha $\beta$-pregueada nas proteínas Lp35 e Lp30.

- A imunização dos animais, com a vacina comercial, bacterina $+\mathrm{Al}(\mathrm{OH})_{3}$ ou FliCi, foi capaz de induzir uma resposta imune humoral específica contra a bacterina do sorovar Copenhageni e contra três das sete proteínas recombinantes avaliadas. As proteínas Lp25, Lp11, Lp30 e Lp35 não foram reconhecidas por este soro e as proteínas Lp25, Lp22 e a LigAc foram as mais imunogênicas

-A imunização dos animais, com o pool de proteínas, foi capaz de induzir uma resposta imune humoral específica contra cada proteína recombinante. As proteínas mais imunogênicas foram Lp21, Lp22, Lp35 e Lp30, seguidas pelas proteínas Lp11 e Lp25 nos grupos imunizados com o pool + FliC $i$. Nos grupos imunizados com pool $+\mathrm{Al}(\mathrm{OH})_{3}$ a proteína que apresentou maior título foi a $\operatorname{Lp} 21$.

- Os resultados, obtidos por ELISA, indicam que os soros dos animais imunizados com as diferentes preparações vacinais, na presença de $\mathrm{FliC} i$, apresentam títulos de anticorpos maiores contra as proteínas recombinantes ou bacterina do que quando o hidróxido de alumínio administrado como adjuvante.

- A especificidade do reconhecimento das proteínas recombinantes, pelos soros dos animais imunizados com o pool de proteínas, foi confirmada por western-blotting.

- Hamsters imunizados com LigAc, ou LigAc co-administrada com o pool das proteínas, acrescido de $\mathrm{FliC} i$ ou $\mathrm{Al}(\mathrm{OH})_{3}$, foram protegidos do desafio letal (86-100\%). 
- Os animais imunizados, com o pool $+\mathrm{Al}(\mathrm{OH})_{3}$, foram parcialmente protegidos $(50 \%)$ e os animais vacinados, com o pool + FliC $i$, morreram com sintomas de leptospirose.

- Animais controle negativos, imunizados com PBS acrescido de $\mathrm{FliC} i$ ou $\mathrm{Al}(\mathrm{OH})_{3}$, morreram e os animais imunizados com vacina comercial, bacterina com FliCi ou $\mathrm{Al}(\mathrm{OH})_{3}$, sobreviveram ao desafio (97-100\%).

-Somente os grupos imunizados com a vacina comercial, bacterina e $\mathrm{Pool}+\mathrm{LigAc}+\mathrm{FliC} i$ apresentaram redução na colonização renal (0-28\%).

-Os resultados do teste de SAM e inibição do crescimento bacteriano revelaram que somente os soros dos animais imunizados com a vacina comercial, bacterina $+\mathrm{Al}(\mathrm{OH})_{3}$, bacterina + FliC $i$ apresentaram aglutinação e neutralização de leptospiras.

- Dados preliminares sugerem um aumento da expressão dos genes das citocinas de resposta Th1 e Th2 nos grupos que apresentaram proteção e diminuição do número de animais portadores. 


\section{REFERÊNCIAS ${ }^{1}$}

ADLER, B.; DE LA PEÑA MOCTEZUMA, A. Leptospira and leptospirosis. Vet. Microbiol., v. 27, n. 140, p. 287-296, 2010.

AKIRA, S.; TAKEDA, K. Toll-like receptor signalling. Nat. Ver. Immunol., v. 4, n. 7, p. 499-511, 2004.

AKIRA, S.; TAKEDA, K.; KAISHO, T. Toll Like receptor: Critical proteins limking innate and acquired immunity. Nat. Immunol., v. 2, n. 8, p. 675-680, 2001.

ALEXANDER, A. D. Leptospira. In: BRAUDE, A.I.; DAVIS, C.E.; FIERER. J. Infectious Diseases and Medical Microbiology. 2nd ed. Philadelphia: W.B. Saunders, 1986.

ANDERSEN-NISSEN, E.; SMITH, K. D.; BONNEAU, R.; STRONG, R. K.; ADEREM, A. A conservade surface on Toll-like receptor 5 recognizes bacterial flagellin. JEM, v. 204, n. 2, p. 393-403, 2007.

ATZINGEN, M. V.; BARBOSA, A. S.; DE BRITO, T.; VASCONCELLOS, S. A.; DE MORAIS, Z. M.; LIMA, D. M.; ABREU, P. A.; NASCIMENTO, A. L. Lsa21, a novel leptospiral protein binding adhesive matrix molecules and present during human infection. BMC Microbiol., v. 29, n. 8, p. 70, 2008.

BABU, M. M.; SANKARAN, K. DOLOP- Database of bacterial lipoprotein. Bioinformatics, v. 18, p. 641-643, 2002.

BARBOSA, A. S.; ABREU, P. A.; NEVES, F. O.; ATZINGEN, M. V.; WATANABE, M. M.; VIEIRA, M. L.; MORAIS, Z. M.; VASCONCELLOS, S. A.; NASCIMENTO A. L. A newly identified leptospiral adhesin mediates attachment to laminin. Infect. Immun., v. 74, n. 11, p. 6356-6364, 2006.

BARBOSA, A. S.; MONARIS, D.; SILVA, L. B.; MORAIS, Z. M.; VASCONCELLOS, S,A,; CIANCIARULlO, A. M.; ISAAC, L.; ABREU, P. A. Functional characterization of LcpA, a surface-exposed protein of Leptospira spp. that binds the human complement regulator C4BP. Infect. Immun., v. 78, n. 7, p. 3207-3216, 2010.

${ }^{1}$ De acordo com: ASSOCIAÇÃO BRASILEIRA DE NORMAS TÉCNICAS. NBR 6023: Informação e documentação: referências: elaboração. Rio de Janeiro, 2002. 
BHARTI, A. R.; NALLY, J. E.; RICALDI, J. N.; MATTHIAS, M. A.; DIAZ, M. M.; LOVETT, M. A.; LEVETT. P. N.; GILMAN, R. H.; WILLIG, M. R.; GOTUZZO, E.; VINETZ, J. M. Leptospirois: a zoonotic diease of global importance. The Lancet Infections Diseases, v. 3, p. 757-771, 2003.

BRAGA, C. J. M.; MASSIS, L. M.; ALENCAR, B. C. G.; RODRIGUES, M. M.; SBROGIOALMEIDA; FERREIRA, L. C. S. Cytotoxic T cell adjuvant effects of three Salmonella enterica flagellins. Braz. J. Microbio., v. 39, p. 44-49, 2008.

BRANGER, C.; CHATRENET, B.; GAUVRIT, A.; AVIAT, F.; AUBERT, A.; BACH, J. M.; ANDRÉ-FONTAINE, G. Protection against Leptospira interrogans sensu lato challenge by DNA immunization with the gene encoding hemolysin-associated protein 1 . Infection. Immun., v. 73, n. 7, p. 4062-4069, 2005.

BRANGER, C.; SONRIER, C.; CHATRENET, B.; KLONJKOWSKI, B.; RUVOENCLOUET, N.; AUBERT, A.; ANDRÉ-FONTAINE, G.; ELOIT, M. Identification of the hemolysis-associated protein 1 as a cross-protective immunogen of Leptospira interrogans by adenovirus-mediated vaccination. Infection. Immun., v. 69, n. 11, p. 6831-6838, 2001.

BRENNER, D. J.; KAUFMANN, A. F.; SULZER, K. R.; STEIGERWALT, A. G.; ROGER, F.; WEYANT, R. S. Further determination of DNA relatedness beteween serougroups and sorovars in the family Leptospiraceae with a proposal for Leptospira alexanderi sp now and four new Leptospira genomospecies. Int. J. Syst. Bacteriol., v. 49, p. 839-858, 1999.

BULACH, D. M.; ZUERNER, R. L.; WILSON, P.; SEEMANN, T.; MCGRATH, A.; CULLEN, P. A.; DAVIS, J.; JOHNSON, M.; KUCZEK, E.; ALT, D. P.; PETERSONBURCH, B.; COPPEL, R. L.; ROOD, J. I.; DAVIES, J. K.; ADLER, B. Genome reduction in Leptospira borgpetersenii reflects limited transmission potential. Proc. Natl. Acad. Sci. USA., v. 103, n. 39, p. 14560-14565, 2006.

BURNETTE, W. N. Western blotting": electrophoretic transfer of proteins from sodium dodecyl sulfate--polyacrylamide gels to unmodified nitrocellulose and radiographic detection with antibody and radioiodinated protein A. Anal. Biochem., v. 112, n. 2, p. 195-203, 1981.

CERQUEIRA, G. M. Caracterização de Leptospira spp quanto à presença e conservação dos genes da família lig: importantes alvos para utilização em vacina e testes de diagnóstico. 2006. 53 f. Dissertação (Mestrado em Biotecnologia) - Programa Biotecnologia Agrícola, Universidade Federal de Pelotas, Rio Grande do Sul, 2006. 
CERQUEIRA, G. M.; MCBRIDE, A. J.; PICARDEAU, M.; RIBEIRO, S. G.; MOREIRA, A. N.; MOREL, V.; REIS, M. G.; KO, A. I.; DELlAGOSTIN, O. A. Distribution of the leptospiral immunoglobulin-like (lig) genes in pathogenic Leptospira species and application of ligB to typing leptospiral isolates. J. Med. Microbiol., v. 58, p. 1173-1181, 2009.

CHANG, Y. F.; CHEN, C. S.; PALANIAPPAN, R. U.; HE, H.; MCDONOUGH, S. P.; BARR, S. C.; YAN, W.; FAISAL, S. M.; PAN, M. J.; CHANG, C. F. Immunogenicity of the recombinant leptospiral putative outer membrane proteins as vaccine candidates. Vaccine, $\mathrm{v}$. 23, n. 48, p. 8190-8197, 2007.

COMBET, C.; BLANCHET, C.; GEOURJON, C.; DELÉAGE, G. NPS@ @ network protein sequence analysis. Trends Biochem. Sci., v. 25, n. 3, p. 147-150, 2000.

DE BRITO, T.; FREYMÜLLER, E.; HOSHINO, S.; PENNA, D. O. Pathology of the kidney and liver in the experimental leptospirosis of the guinea-pig. A light and electron microscopy study. Virchows Arch. Pathol. Anat. Physiol. Klin. Med., v. 13, n. 341, p. 64-78, 1966.

FAINE, S.; ADLER, B.; BOLIN, C.; PEROLAT, P. Leptospira and Leptospirosis. 2nd ed. Melbourne, Australia: MediSci., 1999.

FAISAL, S. M.; YAN, W.; CHEN, C. S.; PALANIAPPAN, R. U.; MCDONOUGH, S. P.; CHANG, Y. F. Evaluation of protective immunity of Leptospira immunoglobulin like protein A (LigA) DNA vaccine against challenge in hamsters. Vaccine, v. 10, n. 2, p. 277-287, 2008.

FAISAL, S. M.; YAN, W.; MCDONOUGH, S. P.; CHANG, C. F.; PAN, M. J.; CHANG, Y. F. Leptosome-entrapped leptospiral antigens conferred significant higher levels of protection than those entrapped with PC-liposomes in a hamster model. Vaccine, v. 27, n. 47, p. 65376545, 2009.

FARR, R. W. Leptospirosis. Clin. Infect. Dis., v. 21, p. 1-8, 1995.

GAMBERINI, M.; GÓMEZ, R. M.; ATZINGEN, M. V.; MARTINS E. A. L.; VASCONCELlOS, S. A.; ROMERO, E. C.; LEITE, L. C. C.; HO, P. L.; NASCIMENTO, A. L. T. O. Whole-genome analysis of Leptospira interrogans to identify potential vaccine candidates against leptospirosis. Fems. Microbiology Letters, v. 244, p. 305-313, 2005.

HAAKE, D. A.; MAZEL, M. K.; MCCOY, A. M.; MILWARD, F.; CHAO, G.; MATSUNAGA, J. WAGAR, E. A. Leptospiral outer membrane proteins OmpL1 and LipL41 exhibit synergistic immunoprotection. Infection and immunity, v. 67, p. 6572-6582, 1999. 
HAAKE, D. A.; MAZEL, M. K.; MCCOY, A. M.; MILWARD, F.; CHAO, G.; MATSUNAGA, J. WAGAR, E. A. Leptospiral outer membrane proteins OmpL1 and LipL41 exhibit synergistic immunoprotection. Infection and immunity, v. 67, n. 6572-6582, 1999.

HOTEZ, P. J.; FERRIS, M. T. The antipoverty vaccines. Vaccine, v. 24, p. 5787-5799, 2006.

HULEATT, J. W.; NAKAAR, V.; DESAI, P.; HUANG, Y.; HEWITT, D.; JACOBS, A.; TANG, J.; MCDONALD, W.; SONG, L.; EVANS, R. K.; UMLAUF, S.; TUSSEY, L.; POWELL, T. J. Potent immunogenicity and efficacy of a universal influenza vaccine candidate comprising a recombinant fusion protein linking influenza M2e to the TLR5 ligand flagellin. Vaccine, v. 26, p. 201-214, 2008.

IWASAKI, A.; MEDZHITOV, R. Toll-like receptor control of the adaptative immune responses. Nat. Immunol., v. 5, n. 10, p. 987-995, 2004.

JANEWAY, J. R. C. A.; MEDZHITOV, R. Innate Immune induction of the adaptative immune response. Cold Spring Harb. Symp. Quant. Biol., v. 64, p. 429-435, 1999.

JOST, B. H.; ADLER, B.; VINH, T.; FAINE, S. A monoclonal antibody reacting with a determinant on leptospiral lipopolysaccharide protects guinea pigs against leptospirosis. J. Med Microbiol., v. 22, n. 3, p. 269-275, 1986.

KELLY, S. M.; JESS, T. J.; PRICE, N. C. How to study proteins by circular dichroism. Biochimica et Biophysica Acta., v. 1751, p. 119-139, 2005.

KO, A. I.; GALVAO REIS, M.; RIBEIRO DOURADO, C. M.; JOHNSON, W. D.; RILEY JR, L. W. Urban epidemic of severe leptospirosis in Brazil. Lancet, v. 354, p. 820-825, 1999.

KOIZUMI, N.; WATANABE, H. Leptospiral immunoglobulin-like proteins elicit protective immunity. Vaccine, v. 22, n. 11-12, p. 1545-1552, 2004.

LEE, S. E.; KIM, S. Y.; JEONG, B. C.; KIM, Y. R.; BAE, S. J.; AHN, O. S.; LEE, J. J.; SONG, H. C.; KIM, J. M.; CHOY, H. E.; CHUNG, S. S.; KWEON, M. N.; RHEE, J. H. A bacterial flagellin, Vibrio vulnificus $\mathrm{FlaB}$, has a strong mucosal adjuvant activity to induce protective immunity. Infect. Immun., v. 74, n. 1, p. 694-702, 2006.

LEVETT, P. N. Leptospirosis. Clinical Microbiology Reviews, v. 14, n. 2, p. 296-326, 2001. 
LEVETT, P. N. Usefulness of serologic analysis as a predictor of the infecting serovar in patients with severe leptospirosis. Clin. Infect. Dis., v. 36, p. 447-452, 2003.

LIVAK, K. J.; SCHMITTGEN, T. D. Analysis of relative gene expression data using realtime quantitative PCR and the $2^{-\Delta \Delta C_{\mathrm{T}}}$ Method. Methods, v. 25, n. 4, p. 402-408, 2001.

LOMAR, A. V.; DIAMENT, D.; TORRES, J. R. Leptospirosis in Latina America. Infect. Dis. Clin. North Am., v. 14, n. 1, p. 23-39, 2000.

MATSUNAGA, J.; BAROCCHI, M. A.; CRODA, J.; YOUNG, T. A.; SANCHEZ, Y.; SIQUEIRA, I.; BOLIN, C. A.; REIS, M. G.; RILEY, L. W.; HAAKE, D. A.; KO, A. I. Pathogenic Leptospira species express surface-exposed proteins belonging to the bacterial immunoglobulin superfamily. Mol. Microbiol., v. 49, n. 4, p. 929-945, 2003.

MCBRIDE, A. J; ATHANAZIO, D. A.; REIS, M. G.; KO, A. I. Leptospirosis. Curr. Opin. Infect. Dis., v. 18, p. 376-386, 2005.

MCDONALD, W. F.; HULEATT, J. W.; FOELLMER, H. G.; HEWITT, D.; TANG, J.; DESAI, P.; PRICE, A.; JACOBS, A,.; TAKAHASHI, V. N.; HUANG, Y.; NAKAAR, V.; ALEXOPOULOU, L.; FIKRIG, E.; POWELL, T. J. A West Nile virus recombinant protein vaccine that coactivates innate and adaptive immunity. J. Infect. Dis., v. 195, n. 11, p. 16071617, 2007.

MIROUX, B.; WALKER, J. E. Over-production of proteins in Escherichia coli: mutant hosts that allow synthesis of some membrane proteins and globular proteins at high levels. J. Mol. Biol., v. 260, n. 3, p. 289-298, 1996.

NAIMAN, B. M.; ALT, D.; BOLIN, C. A.; ZUERNER, R.; BALDWIN, C. L. Protective killed Leptospira borgpetersenii vaccine induces potent Th1 immunity comprising responses by CD4 and gammadelta T lymphocytes. Infect. Immun., v. 69, n. 12, p. 7550-7558, 2001.

NASCIMENTO, A. L.; KO, A. I.; MARTINS, E. A.; MONTEIRO-VITORELLO, C. B.; et al. Comparative genomics of two Leptospira interrogans serovars reveals novel insights into physiology and pathogenesis. J. Bacteriol., v. 186, n. 7, p. 2164-2172, 2004 b.

NASCIMENTO, A. L.; VERJOVSKI-ALMEIDA, S.; VAN SLUYS, M. A.; MONTEIROVITORELLO C. B.; CAMARGO L. E. A.; DIGIAMPIETRI, L. A.; HARSTKEERL, R. A.; HO, P. L.; MARQUES, M. V.; OLIVEIRA, M. C.; SETUBAL, J. C.; HAAKE D. A.; MARTINS, E. A. L. Genome features of Leptospira interrogans serovar Copenhageni. Braz. J. Med. Biol. Res., v. 37, n. 4, p. 459-477, 2004a. 
NEWTON, S. M.; JACOB, C. O.; STOCKER, B. A. Immune response to cholera toxin epitope inserted in Salmonella flagellin. Science, v. 244, n. 4900, p. 70-72, 1989.

NEWTON, S. M.; KOTB, M.; POIRIER, T. P.; STOCKER, B. A.; BEACHEY, E. H. Expression and immunogenicity of a streptococcal M protein epitope inserted in Salmonella flagellin. Infect. Immun., v. 59, n. 6, p. 2158-2165, 1991.

NISHI, S. M.; VIERO, L. M.; SOARES, M. S.; MAIORKA, P. C.; GENNARIL, S. M. Emprego da RT-PCR em tempo real para a quantificação da expressão de genes associados à resposta imune em bezerros bovinos experimentalmente infectados por Neospora caninum,

Rev. Bras. Parasitol. Vet., v. 18, n. 1, p. 8-14, 2009.

PALANIAPPAN, R. U.; RAMANUJAM, S.; CHANG, Y. F. Leptospirosis: pathogenesis, immunity, and diagnosis. Curr. Opin. Infect. Dis., v. 20, n. 3, p. 284-292, 2007.

PALANIAPPAN, R. U.; CHANG, Y. F.; JUSUF, S. S.; ARTIUSHIN, S.; TIMONEY, J. F.; MCDONOUGH, S. P.; BARR, S. C.; DIVERS, T. J.; SIMPSON, K. W.; MCDONOUGH, P. L.; MOHAMMED, H. O. Cloning and molecular characterization of an immunogenic LigA protein of Leptospira interrogans. Infect. Immun., v. 70, n. 11, p. 5924-5930, 2002.

PICARDEAU, M.; BULACH, D. M.; BOUCHIER, C.; ZUERNER, R. L.; ZIDANE, N.; WILSON, P. J.; CRENO, S.; KUCZEK, E. S.; BOMMEZZADRI, S.; DAVIS, J. C.; MCGRATH, A.; JOHNSON, M. J.; BOURSAUX-EUDE, C.; SEEMANN, T.; ROUY, Z.; COPPEL, R. L.; ROOD, J. I.; LAJUS, A.; DAVIES, J .K.; MÉDIGUE, C.; ADLER, B. Genome sequence of the saprophyte Leptospira biflexa provides insights into the evolution of Leptospira and the pathogenesis of leptospirosis. PLoS One, v. 3, n. 2, p. 1607, 2008.

RAMOS, C. R.; ABREU, P. A. E.; NASCIMENTO, A. L.; HO, P. L. A high-copy T7 Escherichia coli expression vector for the production of recombinant proteins with a minimal N-terminal His-tagged fusion peptide. Braz. J. Med. Biol. Res., v. 37, p. 1103-1109, 2004a.

RAMOS, H. C.; RUMBO, M.; SIRARD, J. C. Bacterial flagellins: mediators of pathogenicity and host immune responses in mucosa. Trendes Microbiol., v.12, n. 11, p. 509-517, 2004b.

RANDALL, R.; COOPER, H. K. The golden hamster (Cricetus auratus) as test animal for diagnosis the leptospirosis. Science, v. 100, p. 133-134, 1944.

RAPPUOLI, R.; MEDINI, D.; SIENA, E.; BUDRONI, S.; DORMITZER, P. R.; DEL GIUDICE, G. Building an insurance against modern pandemics. Curr. Opin. Investig. Drugs., v. 11, n. 2, p. 126-130, 2010. 
REED, L. J.; MUENCH, H. a simple method of estimating fifty percent endpoints. Am. J. Hyg., v. 27, p. 493-497, 1938.

REIS, R. B.; RIBEIRO, G. S.; FELZEMBURGH, R. D.; SANTANA, F. S.; MOHR, S.; MELENDEZ, A. X.; QUEIROZ, A.; SANTOS, A. C.; RAVINES, R. R.; TASSINARI, W. S.; CARVALHO, M. S.; REIS, M. G.; KO, A.I. Impact of environment and social gradient on leptospira infection in urban slums. PLoS Negl. Trop. Dis., v. 23, n. 4, p. 228, 2008.

REN, S. X.; FU, G.; JIANG, X. G.; ZENG, R.; MIAO, Y. G.; XU, H.; ZHANG, Y. X.; XIONG, H.; LU, G.; LU, L. F.; JIANG, H. Q.; JIA, J.; TU, Y. F.; JIANG, J. X.; GU, W. Y.; ZHANG, Y. Q.; CAI, Z.; SHENG, H. H.; YIN, H. F.; ZHANG, Y.; ZHU, G. F.; WAN, M.; HUANG, H. L.; QIAN, Z.; WANG, S. Y.; MA, W.; YAO, Z. J.; SHEN, Y.; QIANG, B. Q.; XIA, Q. C.; GUO, X. K.; DANCHIN, A.; SAINT GIRONS, I.; SOMERVILLE, R. L.; WEN, Y. M.; SHI, M. H.; CHEN, Z.; XU, J. G.; ZHAO, G. P. Unique physiological and pathogenic features of Leptospira interrogans revealed by whole-genome sequencing. Nature, v. 422, n. 6934, p. 888-893, 2003.

RESENDE, F. C. B.; PASSOLD, J.; FERREIRA, S. I. A. C.; ZANETTI C. R.; LIMA, H. C. Vacine adjuvants: possibilities for use in humans or animals, Rev. Bras. Alerg. Imunopatol., v. 27, n. 3, p. 116-124, 2004.

RODRIGUES, R. O. Imunogenicidade de bacterinas anti-leptospiras para bovinos produzidas no Brasil, 2006/7. 2008. 145 f. (Doutorado em Veterinária) - Escola de Veterinária, Universidade Federal de Minas Gerais, 2008.

SAMBROOK, J.; FRITSCH, E. F.; MANIATIS, T. Molecular Cloning a laboratory manual. 2nd ed. New York: Cold Spring Harbor Laboratory Press, 1989.

SBROGIO-ALMEIDA, M. E.; MOSCA, T.; MASSIS, L. M.; ABRAHAMSOHN, I. A.; FERREIRA, L. C. Host and bacterial factors affecting induction of immune responses to flagellin expressed by attenuated Salmonella vaccine strains. Infect. Immun., v. 72, n. 5, p. 2546-2555, 2004.

SETUBAL, J. C.; REIS, M.; MATSUNAGA, J. HAAKE, D. A. Lipoprotein computational prediction in spirochaetal genomes. Microbiology, v. 152, p. 113-121, 2006. 
SILVA, E. F.; MEDEIROS, M. A.; MCBRIDE, A. J. A.; MATSUNAGA, J.; ESTEVES, G. S.; RAMOS, J. G. R.; SANTOS, C. S.; CRODA, J.; HOMMA, A.; DELLAGOSTIN, O. A.; HAAKE, D. A.; MITERMAYER, G. R.; KO, A. I. The terminal portion of leptospiral immunoglobulin-like protein LigA conferes protective immunity against lethal infection in the hamster model of leptospirosis. Vaccine, v. 25, p. 6277-6286, 2007.

SISTEMA ÚNICO DE SAÚDE (SUS). Leptospirose. 2009. Disponível em: <http://www.saude.gov.br>. Acesso em: 14 nov. 2009.

SMITH, K. D.; ANDERSEN-NISSEN, E.; HAYASHI, F.; STROBE, K.; BERGMAN, M. A.; BARRETT, S. L.; COOKSON, B. T.; ADEREM, A. Toll-like receptor 5 recognizes a conserved site on flagellin required for protofilament formation and bacterial motility. Nat. Immunol., v. 4, n. 12, p. 1247-1253, 2003.

SONRIER, C.; BRANGER, C.; MICHEL, V.; RUVOËN-CLOUET, N.; GANIÈRE, J. P.; ANDRÉ-FONTAINE, G. Evidence of cross-protection within Leptospira interrogans in an experimental model. Vaccine, v. 19, n. 1, p. 86-94, 2000.

SORENSEN, H. P.; MORTENSEN, K. K. Advanced genetic strategies for recombinant protein expression in E.Coli. Journal of Biotechnology, v. 115, p. 113-128, 2005.

SOTO, F. R. M. Imunidade ativa e passiva em suínos vacinados contra leptospirose. Emprego de vacina experimental de subunidade e duas bacterinas comerciais de bactérias completas. 2006. $114 \mathrm{f}$. Tese (Doutorado em Epidemiologia Experimental aplicado as zoonoses) - Faculdade de Medicina Veterinária e Zootecnia, Universidade de São Paulo, São Paulo, 2006.

SRIKRAM, A.; WONGRATANACHEEWIN, S.; PUAPAIROJ, A.; WUTHIEKANUN, V.; SERMSWAN, R. W. Analyses of vaccination protocols for Leptospira interrogans serovar autumnalis in hamsters. Am. J. Trop. Med. Hyg., v. 79, n. 5, p. 779-786, 2008.

STEINER, T. S. How flagellin and Toll-like receptor 5 contribute to enteric infection. Infec. Immun., v. 75, n. 2, p. 545-552, 2007.

SUTCLIFFE, I. C.; HARRINGTON, D. J. Lipoproteins of Mycobacterium tuberculosis: an abundant and functionally diverse class of cell envelope components. FEMS Microbiology Reviews, v. 28, p. 645-659, 2004.

TAKEDA, K.; KAISHO, T.; AKIRA, S. Toll-like receptors. Annu. Ver. Immunol., v. 21, p. 335-376, 2003. 
VERNEL-PAUILLAC, F.; MERIEN, F. Proinflammatory and immunomodulatory cytokine mrna time course profiles in hamsters infected with a virulent variant of Leptospira interrogans. Infection and Immunity, v. 74, n. 7, p. 4172-4179, 2006.

VIEIRA, M. L.; D'ATRI, L. P.; SCHATTNER, M.; HABARTA, A. M.; BARBOSA, A. S.; DE MORAIS, Z. M.; VASCONCELLOS, S. A.; ABREU, P. A. E.; GÓMEZ, R. M.; NASCIMENTO, A. L. A novel leptospiral protein increases ICAM-1 and E-selectin expression in human umbilical vein endothelial cells. FEMS Microbiol. Lett., v. 276, n. 2, p. 172-180, 2007.

VINETZ, J. M. Leptospirosis. Curr. Opin. Infect. Dis., v. 14, n. 5, p. 527-538, 2001.

WANG, Z.; JIN, L.; WEGRZYN, A. Leptospirosis vaccines. Microb. Cell. Fact., v. 6, n. 39, 2007.

YAN, W.; FAISAL, S. M.; MCDONOUGH, S. P.; DIVERS, T. J.; BARR, S. C.; CHANG, C. F.; PAN, M. J.; CHANG, Y. F. Immunogenicity and protective efficacy of recombinant Leptospira immunoglobulin-like protein B (rLigB) in a hamster challenge model. Microbes Infect., v. 11, n. 2, p. 230-237, 2009.

YASUDA, P. H.; STEIGERWALT, A. G; SULZER, K. R.; KAUFMANN, A. F; ROGER, F; BRENNER, D. J. Deoxyribonucleic acid relatedness beteween serougroups and sorovars for seven new Leptospira species. Int. J. Syst. Bacteriol., v. 37, p. 407-415, 1987.

ZEIGLER, J. A.; JONES, R. H.; KUBIC, K. Immunization against leptospirosis: vaccine trials with heat-killed whole cell and outer envelope antigens in hamsters. Bull. Pan. Am. Health Org., v. 10, p. 126-130, 1976. 


\section{ANEXOS}

ANEXO A - Cálculo DL 50 (parte I- primeiro ensaio de desafio)

Cálculo $\mathrm{DL}_{50}$ do $1^{\circ}$ desafio

\begin{tabular}{|c|c|c|c|c|c|c|c|}
\hline \multirow{2}{*}{ Diluição } & \multirow{2}{*}{$\begin{array}{c}\text { Número de } \\
\text { leptospiras }(N)\end{array}$} & \multirow{2}{*}{$S$} & \multirow{2}{*}{$M$} & \multicolumn{3}{|c|}{ Freqüiências acumuladas } & \multirow{2}{*}{$\begin{array}{c}\text { \% cumulativa } \\
\text { de mortes } \\
d=c /(b+c)\end{array}$} \\
\hline & & & & $S(b)$ & $M(c)$ & Total $(b+c)$ & \\
\hline $10^{-1}$ & $10^{6}$ & 1 & 4 & 1 & 18 & 19 & 94,73 \\
\hline $10^{-2}$ & $10^{5}$ & 0 & 5 & 1 & 14 & 15 & 93,33 \\
\hline $10^{-3}$ & $10^{4}$ & 3 & 2 & 4 & 9 & 13 & 69,23 \\
\hline $10^{-4}$ & $10^{3}$ & 1 & 4 & 5 & 7 & 12 & 58,33 \\
\hline $10^{-5}$ & $10^{2}$ & 2 & 3 & 7 & 3 & 10 & 30,00 \\
\hline
\end{tabular}

$\mathrm{N}=$ número de leptospiras por dose

$\mathrm{S}=$ número de animais sobreviventes à infecção por L. interrogans Copenhageni

$\mathrm{M}=$ número de animais sobreviventes à infecção por L. interrogans Copenhageni

Os animais foram inoculados com $200 \mu \mathrm{l}$ da cultura ( $2 \times 10^{5}$ leptospiras/animal)

Cálculo da distância proporcional $(\mathrm{D})=\underline{50 \%-\mathrm{A}}$

Sendo:

(B-A)

$\mathrm{D}=$ distância entre o ponto $50 \%$ e a cumulativa de morte imediatamente abaixo deste.

$\mathrm{A}=\%$ cumulativa de mortes imediatamente abaixo do ponto $50 \%$

$\mathrm{B}=\%$ cumulativa de mortes imediatamente acima do ponto $50 \%$

$\mathrm{D}=\underline{(50-30,00)}=0,50 *$

$(69,23-30,00)$

* Cálculo considerando o grupo mais próximo de mortes cumulativas de 50\% (marcada em amarelo).

Cálculo da DL ${ }_{50}$ em número de leptospiras: $\log _{10}\left(\mathrm{DL}_{50}\right)=\log _{10}(\mathrm{a})+\left[\mathrm{D} \times \log _{10}(\mathrm{~d})\right]$

Sendo:

$\mathrm{DL}_{50}=$ número de leptospiras que promove morte de $50 \%$ dos animais infectados $\mathrm{a}=$ número de leptospiras correspondente ao ponto imediatamente abaixo do $50 \%$ $\mathrm{D}=$ distância proporcional

$\mathrm{d}=$ fator de diluição

$\log _{10}\left(D_{50}\right)=\log _{10}\left(10^{2}\right)+\left[0,50 \times \log _{10}(10)\right]=2,50$

$\mathrm{DL}_{50}=\sim 316,22$ leptospiras 
Cálculo DL50 (parte III- segundo ensaio de desafio)

Cálculo $\mathrm{DL}_{50}$ do $2^{\circ}$ desafio

\begin{tabular}{|c|c|c|c|c|c|c|c|}
\hline \multirow{2}{*}{ Diluição } & \multirow{2}{*}{$\begin{array}{c}\text { Número de } \\
\text { leptospiras }(N)\end{array}$} & \multirow{2}{*}{$S$} & \multirow{2}{*}{$M$} & \multicolumn{3}{|c|}{ Freqüiências acumuladas } & \multirow{2}{*}{$\begin{array}{c}\text { \% cumulativa } \\
\text { de mortes } \\
d=c /(b+c)\end{array}$} \\
\hline & & & & $S(b)$ & $M(c)$ & Total $(b+c)$ & \\
\hline Pura & $10^{6}$ & 0 & 5 & 0 & 20 & 20 & 100,0 \\
\hline $10^{-1}$ & $10^{5}$ & 3 & 2 & 3 & 15 & 18 & 83,33 \\
\hline $10^{-2}$ & $10^{4}$ & 1 & 4 & 4 & 13 & 17 & 76,47 \\
\hline $10^{-3}$ & $10^{3}$ & 2 & 3 & 6 & 9 & 15 & 60,00 \\
\hline $10^{-4}$ & $10^{2}$ & 3 & 2 & 9 & 6 & 15 & 40,00 \\
\hline $10^{-5}$ & $10^{1}$ & 1 & 4 & 10 & 4 & 14 & 28,57 \\
\hline
\end{tabular}

$\mathrm{N}=$ número de leptospiras por dose

$\mathrm{S}=$ número de animais sobreviventes à infecção por L. interrogans Copenhageni

$\mathrm{M}=$ número de animais sobreviventes à infecção por $L$. interrogans Copenhageni

Os animais foram inoculados com $200 \mu 1$ da cultura $\left(2 \times 10^{5}\right.$ leptospiras/animal).

Cálculo da distância proporcional $(\mathrm{D})=\underline{50 \%-\mathrm{A}}$

Sendo:

(B-A)

$\mathrm{D}=$ distância entre o ponto $50 \%$ e a cumulativa de morte imediatamente abaixo deste.

$\mathrm{A}=\%$ cumulativa de mortes imediatamente abaixo do ponto $50 \%$

$\mathrm{B}=\%$ cumulativa de mortes imediatamente acima do ponto $50 \%$

$\mathrm{D}=\underline{(50-28,57)}=0,68 *$

$(60,00-28,57)$

* Cálculo considerando o grupo mais próximo de mortes cumulativas de 50\% (marcada em amarelo).

Cálculo da DL $\mathrm{D}_{50}$ em número de leptospiras: $\log _{10}\left(\mathrm{DL}_{50}\right)=\log _{10}(\mathrm{a})+\left[\mathrm{D} \times \log _{10}(\mathrm{~d})\right]$

Sendo:

$\mathrm{DL}_{50}=$ número de leptospiras que promove morte de $50 \%$ dos animais infectados $\mathrm{a}=$ número de leptospiras correspondente ao ponto imediatamente abaixo do $50 \%$ $\mathrm{D}=$ distância proporcional

$\mathrm{d}=$ fator de diluição

$\log _{10}\left(\mathrm{DL}_{50}\right)=\log _{10}\left(10^{1}\right)+\left[0,68 \times \log _{10}(10)\right]=1,68$

$\mathrm{DL}_{50}=\sim 47,83$ leptospiras 
Cálculo DL50 (parte II- terceiro ensaio de desafio)

Cálculo $\mathrm{DL}_{50}$ do $3^{\circ}$ desafio

\begin{tabular}{|c|c|c|c|c|c|c|c|}
\hline \multirow{2}{*}{ Diluição } & \multirow{2}{*}{$\begin{array}{c}\text { Número de } \\
\text { leptospiras }(N)\end{array}$} & \multirow{2}{*}{$S$} & \multirow{2}{*}{$M$} & \multicolumn{3}{|c|}{ Freqüiências acumuladas } & \multirow{2}{*}{$\begin{array}{c}\text { \% cumulativa } \\
\text { de mortes } \\
d=c /(b+c)\end{array}$} \\
\hline & & & & $S(b)$ & $M(c)$ & Total $(b+c)$ & \\
\hline Sem & $10^{7}$ & 1 & 4 & 1 & 32 & 33 & 96,96 \\
\hline $10^{-1}$ & $10^{6}$ & 2 & 8 & 3 & 28 & 31 & 90,32 \\
\hline $10^{-2}$ & $10^{5}$ & 3 & 2 & 6 & 20 & 26 & 76,92 \\
\hline $10^{-3}$ & $10^{4}$ & 1 & 4 & 7 & 18 & 25 & 72,00 \\
\hline $10^{-4}$ & $10^{3}$ & 0 & 5 & 7 & 14 & 21 & 66,67 \\
\hline $10^{-5}$ & $10^{2}$ & 1 & 4 & 8 & 9 & 17 & 52,94 \\
\hline $10^{-6}$ & 10 & 1 & 4 & 9 & 5 & 14 & 35,71 \\
\hline
\end{tabular}

$\mathrm{N}=$ número de leptospiras por dose

$\mathrm{S}=$ número de animais sobreviventes à infecção por L. interrogans Copenhageni

$\mathrm{M}=$ número de animais sobreviventes à infecção por $L$. interrogans Copenhageni

Os animais foram inoculados com $200 \mu \mathrm{l}$ da cultura ( $2 \times 10^{5}$ leptospiras/animal).

Cálculo da distância proporcional $(\mathrm{D})=\underline{50 \%-\mathrm{A}}$

(B-A)

Sendo:

$\mathrm{D}=$ distância entre o ponto $50 \%$ e a cumulativa de morte imediatamente abaixo deste.

$\mathrm{A}=\%$ cumulativa de mortes imediatamente abaixo do ponto $50 \%$

$\mathrm{B}=\%$ cumulativa de mortes imediatamente acima do ponto $50 \%$

$\mathrm{D}=\underline{(50-35,71)}=0,48^{*}$

$(65-35,71)$

* Cálculo considerando o grupo mais próximo de mortes cumulativas de 50\% (marcada em amarelo).

Cálculo da DL50 em número de leptospiras: $\log _{10}\left(\mathrm{DL}_{50}\right)=\log _{10}(\mathrm{a})+\left[\mathrm{D} \times \log _{10}(\mathrm{~d})\right]$

Sendo:

$\mathrm{DL}_{50}=$ número de leptospiras que promove morte de $50 \%$ dos animais infectados $\mathrm{a}=$ número de leptospiras correspondente ao ponto imediatamente abaixo do $50 \%$ $\mathrm{D}=$ distância proporcional $\mathrm{d}=$ fator de diluição

$\log _{10}\left(\mathrm{DL}_{50}\right)=\log _{10}(10)+\left[0,48 \times \log _{10}(10)\right]=1,48$

$\mathrm{DL}_{50}=\sim 30$ leptospiras 
ANEXO B - Desvios-padrões das médias das curvas de titulação

\section{(Parte I - $1^{\text {a }}$ Sangria)}

\begin{tabular}{|c|c|c|c|c|c|c|c|c|c|c|c|c|c|}
\hline \multicolumn{2}{|c|}{ PRÉ-IMUNE } & \multirow[b]{2}{*}{ Lp25 } & \multirow{2}{*}{$\begin{array}{r}1 \\
0,01\end{array}$} & \multirow{2}{*}{$\begin{array}{r}2 \\
0,01\end{array}$} & \multirow{2}{*}{$\begin{array}{r}3 \\
0,01\end{array}$} & \multirow{2}{*}{$\begin{array}{r}4 \\
0,01\end{array}$} & \multirow{2}{*}{$\begin{array}{r}5 \\
0,01\end{array}$} & \multirow{2}{*}{$\begin{array}{r}6 \\
0,01\end{array}$} & \multirow{2}{*}{$\begin{array}{r}7 \\
0,01\end{array}$} & \multirow{2}{*}{$\begin{array}{r}8 \\
0,00\end{array}$} & \multirow{2}{*}{$\begin{array}{r}9 \\
0,00\end{array}$} & \multirow{2}{*}{$\begin{array}{r}10 \\
0,00\end{array}$} & \multirow{2}{*}{$\begin{array}{r}11 \\
0,00\end{array}$} \\
\hline A & LIC10009 & & & & & & & & & & & & \\
\hline B & LIC10301 & Lp11 & 0,03 & 0,02 & 0,02 & 0,02 & 0,02 & 0,01 & 0,01 & 0,00 & 0,00 & 0,00 & 0,00 \\
\hline C & LIC10507 & Lp21 & 0,21 & 0,13 & 0,09 & 0,06 & 0,03 & 0,02 & 0,01 & 0,00 & 0,00 & 0,00 & 0,00 \\
\hline D & LIC10704 & Lp22 & 0,03 & 0,02 & 0,02 & 0,02 & 0,02 & 0,01 & 0,00 & 0,00 & 0,00 & 0,00 & 0,00 \\
\hline$E$ & LIC11030 & Lp35 & 0,03 & 0,02 & 0,01 & 0,01 & 0,01 & 0,00 & 0,01 & 0,00 & 0,00 & 0,00 & 0,00 \\
\hline $\mathrm{F}$ & LIC11087 & Lp30 & 0,05 & 0,03 & 0,03 & 0,02 & 0,01 & 0,01 & 0,00 & 0,00 & 0,00 & 0,00 & 0,00 \\
\hline G & LigAc & LigAc & 0,39 & 0,34 & 0,23 & 0,16 & 0,08 & 0,04 & 0,02 & 0,01 & 0,00 & 0,00 & 0,00 \\
\hline $\mathrm{H}$ & FliCi & $\mathrm{FliCi}$ & 0,13 & 0,06 & 0,02 & 0,01 & 0,00 & 0,00 & 0,00 & 0,00 & 0,00 & 0,00 & 0,00 \\
\hline \multirow[t]{2}{*}{1} & Bacterina & Bacterina & 0,30 & 0,35 & 0,32 & 0,29 & 0,19 & 0,07 & 0,02 & 0,00 & 0,00 & 0,00 & 0,00 \\
\hline & & & 100 & 200 & 400 & 800 & 1.600 & 3.200 & 6.400 & 12.800 & 25.600 & 51.200 & 102.400 \\
\hline \multicolumn{2}{|c|}{ 2) $\mathrm{PBS}+\mathrm{Al}(\mathrm{OH}) 3$} & & 1 & 2 & 3 & 4 & 5 & 6 & 7 & 8 & 9 & 10 & 11 \\
\hline A & LIC10009 & Lp25 & 0,02 & 0,01 & 0,01 & 0,00 & 0,00 & 0,00 & 0,00 & 0,00 & 0,00 & 0,00 & 0,00 \\
\hline B & LIC10301 & Lp11 & 0,03 & 0,02 & 0,02 & 0,02 & 0,01 & 0,01 & 0,00 & 0,00 & 0,00 & 0,00 & 0,00 \\
\hline C & LIC10507 & Lp21 & 0,15 & 0,10 & 0,10 & 0,09 & 0,07 & 0,04 & 0,03 & 0,01 & 0,01 & 0,00 & 0,00 \\
\hline D & LIC10704 & Lp22 & 0,09 & 0,05 & 0,04 & 0,03 & 0,03 & 0,02 & 0,01 & 0,00 & 0,00 & 0,00 & 0,00 \\
\hline$E$ & LIC11030 & Lp35 & 0,02 & 0,02 & 0,01 & 0,01 & 0,01 & 0,01 & 0,01 & 0,00 & 0,00 & 0,00 & 0,00 \\
\hline $\mathrm{F}$ & LIC11087 & Lp30 & 0,04 & 0,03 & 0,03 & 0,02 & 0,02 & 0,01 & 0,00 & 0,00 & 0,00 & 0,00 & 0,00 \\
\hline G & LigAc & LigAc & 0,34 & 0,37 & 0,31 & 0,23 & 0,15 & 0,09 & 0,05 & 0,02 & 0,01 & 0,00 & 0,00 \\
\hline $\mathrm{H}$ & FliCi & FliCi & 0,17 & 0,07 & 0,03 & 0,01 & 0,00 & 0,00 & 0,00 & 0,00 & 0,00 & 0,00 & 0,00 \\
\hline I & Bacterina & Bacterina & 0,49 & 0,46 & 0,52 & 0,48 & 0,35 & 0,16 & 0,06 & 0,01 & 0,00 & 0,00 & 0,00 \\
\hline & & & 100 & 200 & 400 & 800 & 1.600 & 3.200 & 6.400 & 12.800 & 25.600 & 51.200 & 102.400 \\
\hline & $\mathrm{liCi}$ & & 1 & 2 & 3 & 4 & 5 & 6 & 7 & 8 & 9 & 10 & 11 \\
\hline A & LIC10009 & Lp25 & 0,01 & 0,01 & 0,01 & 0,01 & 0,01 & 0,00 & 0,00 & 0,00 & 0,00 & 0,00 & 0,02 \\
\hline B & LIC10301 & Lp11 & 0,02 & 0,02 & 0,01 & 0,01 & 0,01 & 0,01 & 0,00 & 0,00 & 0,00 & 0,00 & 0,01 \\
\hline C & LIC10507 & Lp21 & 0,10 & 0,04 & 0,01 & 0,04 & 0,04 & 0,03 & 0,02 & 0,01 & 0,00 & 0,00 & 0,01 \\
\hline D & LIC10704 & Lp22 & 0,06 & 0,04 & 0,02 & 0,02 & 0,03 & 0,02 & 0,01 & 0,00 & 0,00 & 0,00 & 0,00 \\
\hline$E$ & LIC11030 & Lp35 & 0,45 & 0,27 & 0,13 & 0,06 & 0,03 & 0,01 & 0,01 & 0,00 & 0,00 & 0,00 & 0,01 \\
\hline $\mathrm{F}$ & LIC11087 & Lp30 & 0,04 & 0,03 & 0,03 & 0,02 & 0,02 & 0,02 & 0,01 & 0,00 & 0,00 & 0,00 & 0,01 \\
\hline G & LigAc & LigAc & 0,39 & 0,38 & 0,35 & 0,28 & 0,19 & 0,11 & 0,06 & 0,04 & 0,01 & 0,01 & 0,02 \\
\hline $\mathrm{H}$ & FliCi & FliCi & 0,46 & 0,44 & 0,50 & 0,50 & 0,46 & 0,34 & 0,20 & 0,11 & 0,05 & 0,03 & 0,03 \\
\hline 1 & Bacterina & Bacterina & 0,33 & 0,36 & 0,31 & 0,26 & 0,21 & 0,09 & 0,03 & 0,01 & 0,01 & 0,00 & 0,00 \\
\hline & & & 100 & 200 & 400 & 800 & 1.600 & 3.200 & 6.400 & 12.800 & 25.600 & 51.200 & 102.400 \\
\hline & Comercial & & 1 & 2 & 3 & 4 & 5 & 6 & 7 & 8 & 9 & 10 & 11 \\
\hline A & LIC10009 & Lp25 & 0,72 & 0,60 & 0,45 & 0,30 & 0,18 & 0,11 & 0,05 & 0,03 & 0,02 & 0,02 & 0,02 \\
\hline B & LIC10301 & Lp11 & 0,05 & 0,02 & 0,02 & 0,02 & 0,01 & 0,01 & 0,01 & 0,02 & 0,02 & 0,01 & 0,02 \\
\hline C & LIC10507 & Lp21 & 0,29 & 0,24 & 0,20 & 0,14 & 0,10 & 0,07 & 0,04 & 0,03 & 0,01 & 0,01 & 0,02 \\
\hline D & LIC10704 & Lp22 & 0,04 & 0,02 & 0,01 & 0,02 & 0,03 & 0,03 & 0,02 & 0,02 & 0,01 & 0,00 & 0,03 \\
\hline$E$ & LIC11030 & Lp35 & 0,03 & 0,03 & 0,02 & 0,02 & 0,02 & 0,02 & 0,01 & 0,02 & 0,01 & 0,01 & 0,07 \\
\hline $\mathrm{F}$ & LIC11087 & Lp30 & 0,14 & 0,07 & 0,04 & 0,02 & 0,03 & 0,02 & 0,01 & 0,02 & 0,01 & 0,02 & 0,07 \\
\hline G & LigAc & LigAc & 0,53 & 0,48 & 0,38 & 0,26 & 0,16 & 0,10 & 0,06 & 0,04 & 0,02 & 0,02 & 0,04 \\
\hline $\mathrm{H}$ & FliCi & FliCi & 0,51 & 0,18 & 0,08 & 0,04 & 0,02 & 0,01 & 0,01 & 0,02 & 0,03 & 0,03 & 0,03 \\
\hline 1 & Bacterina & Bacterina & 0,49 & 0,58 & 0,68 & 0,82 & 0,83 & 0,70 & 0,54 & 0,35 & 0,21 & 0,13 & 0,08 \\
\hline & & & 100 & 200 & 400 & 800 & 1.600 & 3.200 & 6.400 & 12.800 & 25.600 & 51.200 & 102.400 \\
\hline & $\mathrm{na}+\mathrm{Al}(\mathrm{OH})$ & 13 & 1 & 2 & 3 & 4 & 5 & 6 & 7 & 8 & 9 & 10 & 11 \\
\hline A & LIC10009 & Lp25 & 0,00 & 0,01 & 0,01 & 0,01 & 0,01 & 0,00 & 0,00 & 0,00 & 0,00 & 0,00 & 0,00 \\
\hline B & LIC10301 & Lp11 & 0,01 & 0,01 & 0,01 & 0,00 & 0,00 & 0,00 & 0,00 & 0,00 & 0,00 & 0,00 & 0,00 \\
\hline C & LIC10507 & Lp21 & 0,15 & 0,09 & 0,03 & 0,04 & 0,09 & 0,02 & 0,00 & 0,01 & 0,00 & 0,00 & 0,00 \\
\hline D & LIC10704 & Lp22 & 0,07 & 0,02 & 0,04 & 0,03 & 0,02 & 0,02 & 0,01 & 0,00 & 0,00 & 0,00 & 0,00 \\
\hline$E$ & LIC11030 & Lp35 & 0,06 & 0,03 & 0,01 & 0,00 & 0,00 & 0,00 & 0,01 & 0,00 & 0,00 & 0,00 & 0,00 \\
\hline $\mathrm{F}$ & LIC11087 & Lp30 & 0,14 & 0,08 & 0,05 & 0,02 & 0,01 & 0,01 & 0,00 & 0,00 & 0,00 & 0,00 & 0,00 \\
\hline G & LigAc & LigAc & 0,55 & 0,51 & 0,40 & 0,28 & 0,17 & 0,08 & 0,04 & 0,02 & 0,01 & 0,00 & 0,00 \\
\hline $\mathrm{H}$ & FliCi & FliCi & 0,48 & 0,16 & 0,06 & 0,02 & 0,00 & 0,00 & 0,00 & 0,00 & 0,00 & 0,00 & 0,00 \\
\hline I & Bacterina & Bacterina & 0,25 & 0,35 & 0,27 & 0,35 & 0,24 & 0,15 & 0,10 & 0,02 & 0,02 & 0,01 & 0,01 \\
\hline & & & 100 & 200 & 400 & 800 & 1.600 & 3.200 & 6.400 & 12.800 & 25.600 & 51.200 & 102.400 \\
\hline
\end{tabular}




\begin{tabular}{|c|c|c|c|c|c|c|c|c|c|c|c|c|c|}
\hline \multicolumn{2}{|c|}{ 6) Bacterina + FliCi } & & 1 & 2 & 3 & 4 & 5 & 6 & 7 & 8 & 9 & 10 & 11 \\
\hline A & LIC10009 & Lp25 & 0,02 & 0,02 & 0,01 & 0,00 & 0,00 & 0,00 & 0,00 & 0,00 & 0,00 & 0,00 & 0,00 \\
\hline B & LIC10301 & Lp11 & 0,08 & 0,02 & 0,02 & 0,02 & 0,01 & 0,01 & 0,00 & 0,00 & 0,00 & 0,00 & 0,00 \\
\hline C & LIC10507 & Lp21 & 0,59 & 0,62 & 0,51 & 0,33 & 0,21 & 0,11 & 0,03 & 0,02 & 0,00 & 0,00 & 0,00 \\
\hline$E$ & LIC11030 & Lp35 & 0,32 & 0,18 & 0,11 & 0,06 & 0,03 & 0,01 & 0,00 & 0,00 & 0,00 & 0,00 & 0,00 \\
\hline $\mathrm{F}$ & LIC11087 & Lp30 & 0,58 & 0,34 & 0,19 & 0,11 & 0,04 & 0,02 & 0,00 & 0,00 & 0,00 & 0,00 & 0,00 \\
\hline \multirow{2}{*}{ I } & Bacterina & Bacterina & 0,49 & 0,40 & 0,30 & 0,20 & 0,12 & 0,02 & 0,01 & 0,03 & 0,02 & 0,01 & 0,01 \\
\hline & & & 100 & 200 & 400 & 800 & 1.600 & 3.200 & 6.400 & 12.800 & 25.600 & 51.200 & 102.400 \\
\hline \multirow{2}{*}{\multicolumn{2}{|c|}{ 7) $\mathrm{LigAc}+\mathrm{Al}(\mathrm{OH}) 3$}} & & & & & & & & & & & & \\
\hline & & & 1 & 2 & 3 & 4 & 5 & 6 & 1 & 8 & 9 & 10 & 11 \\
\hline A & LIC10009 & Lp25 & 0,08 & 0,05 & 0,02 & 0,01 & 0,01 & 0,00 & 0,00 & 0,00 & 0,00 & 0,00 & 0,00 \\
\hline $\mathrm{F}$ & LIC11087 & Lp30 & 0,26 & 0,16 & 0,08 & 0,06 & 0,03 & 0,01 & 0,00 & 0,00 & 0,00 & 0,00 & 0,00 \\
\hline G & LigAc & LigAc & 0,43 & 0,40 & 0,55 & 0,67 & 0,73 & 0,66 & 0,51 & 0,35 & 0,22 & 0,15 & 0,08 \\
\hline $\mathrm{H}$ & FliCi & FliCi & 0,46 & 0,30 & 0,15 & 0,05 & 0,02 & 0,01 & 0,00 & 0,00 & 0,00 & 0,00 & 0,00 \\
\hline \multirow[t]{2}{*}{ I } & Bacterina & Bacterina & 0,33 & 0,43 & 0,46 & 0,61 & 0,45 & 0,26 & 0,10 & 0,06 & 0,01 & 0,00 & 0,00 \\
\hline & & & 100 & 200 & 400 & 800 & 1.600 & 3.200 & 6.400 & 12.800 & 25.600 & 51.200 & 102.400 \\
\hline \multicolumn{2}{|c|}{ 8) $\mathrm{LigAc}+\mathrm{FliCi}$} & & 1 & 2 & 3 & 4 & 5 & 6 & 7 & 8 & 9 & 10 & 11 \\
\hline A & LIC10009 & Lp25 & 0,03 & 0,03 & 0,01 & 0,02 & 0,01 & 0,01 & 0,01 & 0,01 & 0,01 & 0,00 & 0,00 \\
\hline B & LIC10301 & Lp11 & 0,04 & 0,02 & 0,02 & 0,01 & 0,02 & 0,01 & 0,01 & 0,00 & 0,00 & 0,00 & 0,00 \\
\hline C & LIC10507 & Lp21 & 0,26 & 0,27 & 0,27 & 0,29 & 0,18 & 0,10 & 0,07 & 0,04 & 0,02 & 0,01 & 0,01 \\
\hline D & LIC10704 & Lp22 & 0,21 & 0,18 & 0,15 & 0,11 & 0,07 & 0,06 & 0,10 & 0,02 & 0,01 & 0,01 & 0,00 \\
\hline \multicolumn{2}{|c|}{ 9) $\mathrm{Pool}+\mathrm{Al}(\mathrm{OH}) 3$} & & 1 & 2 & 3 & 4 & 5 & 6 & 7 & 8 & 9 & 10 & 11 \\
\hline A & LIC10009 & Lp25 & 0,58 & 0,30 & 0,06 & 0,22 & 0,04 & 0,06 & 0,02 & 0,00 & 0,02 & 0,02 & 0,01 \\
\hline B & LIC10301 & Lp11 & 0,31 & 0,17 & 0,11 & 0,05 & 0,03 & 0,02 & 0,01 & 0,00 & 0,00 & 0,00 & 0,00 \\
\hline C & LIC10507 & Lp21 & 0,43 & 0,64 & 0,62 & 0,70 & 0,67 & 0,68 & 0,52 & 0,34 & 0,23 & 0,15 & 0,09 \\
\hline D & LIC10704 & Lp22 & 0,26 & 0,02 & 0,10 & 0,08 & 0,15 & 0,09 & 0,09 & 0,06 & 0,04 & 0,02 & 0,01 \\
\hline$E$ & LIC11030 & Lp35 & 0,37 & 0,38 & 0,31 & 0,26 & 0,28 & 0,15 & 0,08 & 0,05 & 0,03 & 0,02 & 0,02 \\
\hline $\mathrm{F}$ & LIC11087 & Lp30 & 0,44 & 0,69 & 0,43 & 0,55 & 0,53 & 0,40 & 0,22 & 0,13 & 0,06 & 0,03 & 0,02 \\
\hline G & LigAc & LigAc & 0,30 & 0,14 & 0,04 & 0,09 & 0,20 & 0,18 & 0,16 & 0,09 & 0,05 & 0,03 & 0,02 \\
\hline $\mathrm{H}$ & $\mathrm{FliCi}$ & $\mathrm{FliCi}$ & 0,55 & 0,10 & 0,10 & 0,02 & 0,01 & 0,00 & 0,00 & 0,00 & 0,00 & 0,00 & 0,00 \\
\hline \multirow[b]{3}{*}{10} & Bacterina & Bacterina & 0,32 & 0,31 & 0,36 & 0,35 & 0,24 & 0,13 & 0,04 & 0,02 & 0,01 & 0,01 & 0,01 \\
\hline & & & 100 & 200 & 400 & 800 & 1.600 & 3.200 & 6.400 & 12.800 & 25.600 & 51.200 & 102.400 \\
\hline & 10) Pool + FliCi & & 1 & 2 & 3 & 4 & 5 & 6 & 7 & 8 & 9 & 10 & 11 \\
\hline A & LIC10009 & Lp25 & 0,86 & 0,84 & 1,13 & 1,43 & 1,59 & 1,46 & 1,07 & 0,66 & 0,30 & 0,14 & 0,07 \\
\hline B & LIC10301 & Lp11 & 0,44 & 0,61 & 0,76 & 0,89 & 1,13 & 1,25 & 1,19 & 0,96 & 0,60 & 0,33 & 0,16 \\
\hline C & LIC10507 & Lp21 & 0,49 & 0,39 & 0,28 & 0,37 & 0,52 & 0,75 & 0,80 & 0,68 & 0,54 & 0,40 & 0,24 \\
\hline D & LIC10704 & Lp22 & 0,69 & 0,82 & 0,87 & 0,96 & 0,94 & 0,81 & 0,84 & 0,70 & 0,52 & 0,34 & 0,20 \\
\hline$E$ & LIC11030 & Lp35 & 0,30 & 0,64 & 0,89 & 1,06 & 1,07 & 1,03 & 1,05 & 0,93 & 0,71 & 0,52 & 0,30 \\
\hline $\mathrm{F}$ & LIC11087 & Lp30 & 0,29 & 0,60 & 0,88 & 1,06 & 1,08 & 1,09 & 1,02 & 0,89 & 0,69 & 0,47 & 0,24 \\
\hline G & LigAc & LigAc & 0,28 & 0,33 & 0,48 & 0,71 & 0,90 & 1,04 & 0,96 & 0,78 & 0,59 & 0,36 & 0,20 \\
\hline $\mathrm{H}$ & FliCi & FliCi & 0,36 & 0,35 & 0,28 & 0,39 & 0,61 & 0,83 & 0,81 & 0,64 & 0,45 & 0,27 & 0,16 \\
\hline
\end{tabular}




\begin{tabular}{|c|c|c|c|c|c|c|c|c|c|c|c|c|c|}
\hline \multicolumn{3}{|c|}{ 11) Pool + Lig A + Al $(\mathrm{OH}) 3$} & 1 & 2 & 3 & 4 & 5 & 6 & 7 & 8 & 9 & 10 & 11 \\
\hline A & LIC10009 & Lp25 & 0,29 & 0,23 & 0,07 & 0,01 & 0,04 & 0,00 & 0,01 & 0,00 & 0,00 & 0,00 & 0,00 \\
\hline C & LIC10507 & Lp21 & 0,45 & 0,43 & 0,32 & 0,30 & 0,22 & 0,11 & 0,06 & 0,03 & 0,01 & 0,00 & 0,00 \\
\hline $\mathrm{E}$ & LIC11030 & Lp35 & 0,03 & 0,09 & 0,12 & 0,09 & 0,05 & 0,03 & 0,02 & 0,01 & 0,00 & 0,00 & 0,00 \\
\hline $\mathrm{F}$ & LIC11087 & Lp30 & 0,52 & 0,43 & 0,35 & 0,24 & 0,13 & 0,09 & 0,05 & 0,02 & 0,01 & 0,01 & 0,01 \\
\hline G & LigAc & LigAc & 0,37 & 0,42 & 0,55 & 0,63 & 0,61 & 0,47 & 0,33 & 0,21 & 0,12 & 0,07 & 0,05 \\
\hline I & Bacterina & Bacterina & 0,31 & 0,24 & 0,35 & 0,42 & 0,37 & 0,25 & 0,11 & 0,05 & 0,02 & 0,01 & 0,01 \\
\hline & & & 100 & 200 & 400 & 800 & 1.600 & 3.200 & 6.400 & 12.800 & 25.600 & 51.200 & 102.400 \\
\hline & 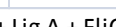 & & & & & & & & & & 0 & 10 & \\
\hline A & LIC10009 & Lp25 & 1,08 & 0,92 & 0,68 & 0,33 & 0,20 & 0,11 & 0,05 & 0,02 & 0,01 & 0,00 & 0,00 \\
\hline B & LIC10301 & Lp11 & 1,26 & 1,37 & 1,23 & 1,04 & 0,83 & 0,54 & 0,32 & 0,17 & 0,08 & 0,04 & 0,02 \\
\hline $\mathrm{F}$ & LIC11087 & Lp30 & 0,52 & 0,69 & 0,66 & 0,75 & 0,61 & 0,45 & 0,27 & 0,13 & 0,06 & 0,03 & 0,02 \\
\hline G & LigAc & LigAc & 0,34 & 0,32 & 0,44 & 0,44 & 0,73 & 0,75 & 0,63 & 0,46 & 0,29 & 0,15 & 0,09 \\
\hline $\mathrm{H}$ & $\mathrm{FliCi}$ & $\mathrm{FliCi}$ & 0,38 & 0,31 & 0,24 & 0,09 & 0,27 & 0,49 & 0,57 & 0,51 & 0,35 & 0,21 & 0,12 \\
\hline I & Bacterina & Bacterina & 0,15 & 0,24 & 0,39 & 0,47 & 0,37 & 0,21 & 0,09 & 0,03 & 0,01 & 0,00 & 0,00 \\
\hline & & & 100 & 200 & 400 & 800 & 1.600 & 3.200 & 6.400 & 12.800 & 25.600 & 51.200 & 102.400 \\
\hline
\end{tabular}


Desvios-padrões das médias das curvas de titulação

\section{(Parte II - 2a Sangria)}

\begin{tabular}{|c|c|c|c|c|c|c|c|c|c|c|c|c|c|}
\hline \multicolumn{2}{|c|}{ 1) PRÉ-IMUNE } & & \multirow{2}{*}{$\begin{array}{r}1 \\
0,01\end{array}$} & \multirow{2}{*}{$\begin{array}{r}2 \\
0,01\end{array}$} & \multirow{2}{*}{$\begin{array}{r}3 \\
0,00\end{array}$} & \multirow{2}{*}{$\begin{array}{r}4 \\
0,00\end{array}$} & \multirow{2}{*}{$\begin{array}{r}5 \\
0,00\end{array}$} & \multirow{2}{*}{$\begin{array}{r}6 \\
0,00\end{array}$} & \multirow{2}{*}{$\begin{array}{r}7 \\
0,00\end{array}$} & \multirow{2}{*}{$\begin{array}{r}8 \\
0,00\end{array}$} & \multirow{2}{*}{$\begin{array}{r}9 \\
0,00\end{array}$} & \multirow{2}{*}{$\begin{array}{r}10 \\
0,00\end{array}$} & \multirow{2}{*}{$\begin{array}{r}11 \\
0,00\end{array}$} \\
\hline$A$ & LIC10009 & Lp25 & & & & & & & & & & & \\
\hline C & LIC10507 & Lp21 & 0,34 & 0,21 & 0,14 & 0,07 & 0,03 & 0,02 & 0,00 & 0,00 & 0,00 & 0,00 & 0,00 \\
\hline$E$ & LIC11030 & Lp35 & 0,05 & 0,02 & 0,01 & 0,01 & 0,01 & 0,00 & 0,00 & 0,00 & 0,00 & 0,00 & 0,00 \\
\hline $\mathrm{F}$ & LIC11087 & Lp30 & 0,06 & 0,04 & 0,02 & 0,10 & 0,00 & 0,00 & 0,00 & 0,00 & 0,00 & 0,00 & 0,00 \\
\hline G & LigAc & LigAc & 0,73 & 0,58 & 0,39 & 0,21 & 0,11 & 0,05 & 0,02 & 0,01 & 0,00 & 0,00 & 0,00 \\
\hline I & & & 100 & 200 & 400 & 800 & 1.600 & 3.200 & 6.400 & 12.800 & 25.600 & 51.200 & 102.400 \\
\hline & & & & & & & & & & & & & \\
\hline & $\mathrm{Il}(\mathrm{OH}) 3$ & & 1 & 2 & 3 & 4 & 5 & 6 & 7 & 8 & 9 & 10 & 11 \\
\hline$A$ & LIC10009 & Lp25 & 0,01 & 0,01 & 0,01 & 0,00 & 0,00 & 0,00 & 0,00 & 0,00 & 0,00 & 0,00 & 0,00 \\
\hline B & LIC10301 & Lp11 & 0,02 & 0,03 & 0,02 & 0,01 & 0,01 & 0,00 & 0,00 & 0,00 & 0,00 & 0,00 & 0,00 \\
\hline G & LigAc & LigAc & 0,56 & 0,51 & 0,38 & 0,23 & 0,14 & 0,08 & 0,03 & 0,01 & 0,00 & 0,00 & 0,00 \\
\hline $\mathrm{H}$ & FliCi & FliCi & 0,29 & 0,10 & 0,03 & 0,02 & 0,01 & 0,00 & 0,00 & 0,00 & 0,00 & 0,00 & 0,00 \\
\hline I & Bacterina & Bacterina & 0,48 & 0,32 & 0,14 & 0,14 & 0,12 & 0,08 & 0,04 & 0,02 & 0,01 & 0,01 & 0,01 \\
\hline & & & 100 & 200 & 400 & 800 & 1.600 & 3.200 & 6.400 & 12.800 & 25.600 & 51.200 & 102.400 \\
\hline & & & & & & & & & & & & & \\
\hline & $\mathrm{liCi}$ & & 1 & 2 & 3 & 4 & 5 & 6 & 7 & 8 & 9 & 10 & 11 \\
\hline A & LIC10009 & Lp25 & 0,03 & 0,02 & 0,02 & 0,02 & 0,02 & 0,01 & 0,00 & 0,00 & 0,00 & 0,00 & 0,00 \\
\hline B & LIC10301 & Lp11 & 0,05 & 0,04 & 0,03 & 0,02 & 0,02 & 0,01 & 0,01 & 0,00 & 0,00 & 0,00 & 0,00 \\
\hline C & LIC10507 & Lp21 & 0,55 & 0,41 & 0,34 & 0,26 & 0,15 & 0,11 & 0,05 & 0,03 & 0,01 & 0,00 & 0,00 \\
\hline D & LIC10704 & Lp22 & 0,19 & 0,12 & 0,09 & 0,07 & 0,05 & 0,04 & 0,02 & 0,01 & 0,00 & 0,00 & 0,00 \\
\hline$E$ & LIC11030 & Lp35 & 0,20 & 0,13 & 0,06 & 0,03 & 0,02 & 0,02 & 0,00 & 0,00 & 0,00 & 0,00 & 0,00 \\
\hline A & LIC10009 & Lp25 & 0,30 & 0,19 & 0,09 & 0,05 & 0,03 & 0,01 & 0,00 & 0,00 & 0,00 & 0,00 & 0,00 \\
\hline B & LIC10301 & Lp11 & 0,09 & 0,04 & 0,03 & 0,03 & 0,12 & 0,00 & 0,00 & 0,00 & 0,00 & 0,00 & 0,00 \\
\hline C & LIC10507 & Lp21 & 0,70 & 0,51 & 0,35 & 0,21 & 0,12 & 0,06 & 0,03 & 0,01 & 0,00 & 0,00 & 0,00 \\
\hline D & LIC10704 & Lp22 & 0,10 & 0,09 & 0,04 & 0,04 & 0,03 & 0,02 & 0,01 & 0,00 & 0,00 & 0,00 & 0,00 \\
\hline$E$ & LIC11030 & Lp35 & 0,16 & 0,09 & 0,06 & 0,02 & 0,01 & 0,00 & 0,00 & 0,00 & 0,00 & 0,00 & 0,00 \\
\hline $\mathrm{F}$ & LIC11087 & Lp30 & 0,23 & 0,12 & 0,07 & 0,03 & 0,02 & 0,01 & 0,01 & 0,00 & 0,00 & 0,00 & 0,00 \\
\hline G & LigAc & LigAc & 0,91 & 0,75 & 0,58 & 0,42 & 0,23 & 0,13 & 0,07 & 0,03 & 0,01 & 0,00 & 0,00 \\
\hline $\mathrm{H}$ & FliCi & FliCi & 0,45 & 0,14 & 0,05 & 0,02 & 0,01 & 0,00 & 0,00 & 0,00 & 0,00 & 0,00 & 0,00 \\
\hline I & Bacterina & Bacterina & 0,56 & 0,56 & 0,60 & 0,80 & 0,79 & 0,77 & 0,69 & 0,50 & 0,34 & 0,20 & 0,11 \\
\hline & & & 100 & 200 & 400 & 800 & 1.600 & 3.200 & 6.400 & 12.800 & 25.600 & 51.200 & 102.400 \\
\hline & & & & & & & & & & & & & \\
\hline & $\mathrm{na}+\mathrm{Al}(\mathrm{OH})$ & ) 3 & 1 & 2 & 3 & 4 & 5 & 6 & 7 & 8 & 9 & 10 & 11 \\
\hline A & LIC10009 & Lp25 & 0,02 & 0,01 & 0,01 & 0,00 & 0,00 & 0,00 & 0,00 & 0,00 & 0,00 & 0,00 & 0,00 \\
\hline B & LIC10301 & Lp11 & 0,03 & 0,29 & 0,01 & 0,01 & 0,00 & 0,00 & 0,00 & 0,00 & 0,00 & 0,00 & 0,00 \\
\hline C & LIC10507 & Lp21 & 0,44 & 0,33 & 0,24 & 0,15 & 0,08 & 0,05 & 0,03 & 0,01 & 0,00 & 0,00 & 0,00 \\
\hline D & LIC10704 & Lp22 & 0,16 & 0,10 & 0,06 & 0,04 & 0,03 & 0,02 & 0,00 & 0,00 & 0,00 & 0,00 & 0,00 \\
\hline$E$ & LIC11030 & Lp35 & 0,43 & 0,24 & 0,10 & 0,04 & 0,01 & 0,00 & 0,00 & 0,00 & 0,00 & 0,00 & 0,00 \\
\hline $\mathrm{F}$ & LIC11087 & Lp30 & 0,19 & 0,08 & 0,03 & 0,01 & 0,01 & 0,01 & 0,00 & 0,00 & 0,00 & 0,00 & 0,00 \\
\hline G & LigAc & LigAc & 0,64 & 0,50 & 0,36 & 0,25 & 0,07 & 0,08 & 0,04 & 0,02 & 0,01 & 0,00 & 0,00 \\
\hline $\mathrm{H}$ & $\mathrm{FliCi}$ & $\mathrm{FliCi}$ & 0,73 & 0,27 & 0,09 & 0,02 & 0,01 & 0,01 & 0,00 & 0,00 & 0,00 & 0,00 & 0,00 \\
\hline I & Bacterina & Bacterina & 0,60 & 0,63 & 0,67 & 0,65 & 0,74 & 0,71 & 0,57 & 0,48 & 0,30 & 0,17 & 0,09 \\
\hline & & & 100 & 200 & 400 & 800 & 1.600 & 3.200 & 6.400 & 12.800 & 25.600 & 51.200 & 102.400 \\
\hline
\end{tabular}




\begin{tabular}{|c|c|c|c|c|c|c|c|c|c|c|c|c|c|}
\hline \multicolumn{2}{|c|}{ 6) Bacterina + FliCi } & \multirow[b]{2}{*}{ Lp25 } & \multirow{2}{*}{$\begin{array}{r}1 \\
0,03\end{array}$} & \multirow{2}{*}{$\begin{array}{r}2 \\
0,01\end{array}$} & \multirow{2}{*}{$\begin{array}{r}3 \\
0,01\end{array}$} & \multirow{2}{*}{$\begin{array}{r}4 \\
0,00\end{array}$} & \multirow{2}{*}{$\begin{array}{r}5 \\
0,00\end{array}$} & \multirow{2}{*}{$\begin{array}{r}6 \\
0,00\end{array}$} & \multirow{2}{*}{$\begin{array}{r}7 \\
0,00\end{array}$} & \multirow{2}{*}{$\begin{array}{r}8 \\
0,00\end{array}$} & \multirow{2}{*}{$\begin{array}{r}9 \\
0,00\end{array}$} & \multirow{2}{*}{$\begin{array}{r}10 \\
0,00\end{array}$} & \multirow{2}{*}{$\begin{array}{r}11 \\
0,00\end{array}$} \\
\hline A & LIC10009 & & & & & & & & & & & & \\
\hline B & LIC10301 & Lp11 & 0,04 & 0,03 & 0,02 & 0,04 & 0,01 & 0,00 & 0,00 & 0,00 & 0,00 & 0,00 & 0,00 \\
\hline C & LIC10507 & Lp21 & 0,62 & 0,48 & 0,29 & 0,16 & 0,08 & 0,04 & 0,02 & 0,01 & 0,00 & 0,01 & 0,01 \\
\hline D & LIC10704 & Lp22 & 0,33 & 0,21 & 0,12 & 0,07 & 0,05 & 0,03 & 0,01 & 0,00 & 0,00 & 0,00 & 0,00 \\
\hline $\mathrm{E}$ & LIC11030 & Lp35 & 0,17 & 0,08 & 0,04 & 0,01 & 0,01 & 0,01 & 0,00 & 0,00 & 0,00 & 0,00 & 0,00 \\
\hline $\mathrm{F}$ & LIC11087 & Lp30 & 0,22 & 0,11 & 0,04 & 0,03 & 0,01 & 0,01 & 0,00 & 0,00 & 0,00 & 0,00 & 0,00 \\
\hline G & LigAc & LigAc & 0,75 & 0,66 & 0,48 & 0,31 & 0,18 & 0,10 & 0,06 & 0,03 & 0,01 & 0,00 & 0,00 \\
\hline $\mathrm{H}$ & FliCi & FliCi & 0,45 & 0,48 & 0,55 & 0,61 & 0,69 & 0,61 & 0,42 & 0,23 & 0,14 & 0,07 & 0,05 \\
\hline \multirow[t]{2}{*}{ I } & Bacterina & Bacterina & 0,70 & 0,72 & 0,75 & 0,78 & 0,83 & 0,76 & 0,60 & 0,39 & 0,24 & 0,13 & 0,09 \\
\hline & & & 100 & 200 & 400 & 800 & 1.600 & 3.200 & 6.400 & 12.800 & 25.600 & 51.200 & 102.400 \\
\hline & $\mathrm{Al}(\mathrm{OH}) 3$ & & 1 & 2 & 3 & 4 & 5 & 6 & 7 & 8 & 9 & 10 & 11 \\
\hline A & LIC10009 & Lp25 & 0,05 & 0,03 & 0,01 & 0,01 & 0,01 & 0,00 & 0,00 & 0,00 & 0,00 & 0,00 & 0,00 \\
\hline B & LIC10301 & Lp11 & 0,09 & 0,05 & 0,03 & 0,02 & 0,02 & 0,01 & 0,01 & 0,00 & 0,00 & 0,00 & 0,00 \\
\hline C & LIC10507 & Lp21 & 0,63 & 0,46 & 0,32 & 0,21 & 0,12 & 0,08 & 0,03 & 0,02 & 0,01 & 0,00 & 0,00 \\
\hline D & LIC10704 & Lp22 & 0,20 & 0,21 & 0,08 & 0,05 & 0,04 & 0,02 & 0,01 & 0,00 & 0,00 & 0,00 & 0,00 \\
\hline$E$ & LIC11030 & Lp35 & 0,45 & 0,23 & 0,11 & 0,05 & 0,01 & 0,01 & 0,00 & 0,00 & 0,00 & 0,00 & 0,00 \\
\hline $\mathrm{F}$ & LIC11087 & Lp30 & 0,62 & 0,37 & 0,19 & 0,09 & 0,04 & 0,02 & 0,01 & 0,00 & 0,00 & 0,00 & 0,00 \\
\hline G & LigAc & LigAc & 0,44 & 0,48 & 0,49 & 0,52 & 0,61 & 0,65 & 0,66 & 0,54 & 0,35 & 0,20 & 0,09 \\
\hline $\mathrm{H}$ & FliCi & FliCi & 0,08 & 0,04 & 0,02 & 0,01 & 0,00 & 0,00 & 0,00 & 0,00 & 0,00 & 0,00 & 0,00 \\
\hline I & Bacterina & Bacterina & 0,40 & 0,27 & 0,16 & 0,03 & 0,05 & 0,02 & 0,02 & 0,01 & 0,01 & 0,01 & 0,01 \\
\hline & & & 100 & 200 & 400 & 800 & 1.600 & 3.200 & 6.400 & 12.800 & 25.600 & 51.200 & 102.400 \\
\hline & FliCi & & 1 & 2 & 3 & 4 & 5 & 6 & 7 & 8 & 9 & 10 & 11 \\
\hline A & LIC10009 & Lp25 & 0,07 & 0,04 & 0,01 & 0,01 & 0,01 & 0,00 & 0,00 & 0,00 & 0,00 & 0,00 & 0,00 \\
\hline B & LIC10301 & Lp11 & 0,09 & 0,03 & 0,01 & 0,01 & 0,01 & 0,01 & 0,00 & 0,00 & 0,00 & 0,00 & 0,00 \\
\hline C & LIC10507 & Lp21 & 0,50 & 0,42 & 0,32 & 0,19 & 0,09 & 0,04 & 0,01 & 0,00 & 0,01 & 0,00 & 0,00 \\
\hline D & LIC10704 & Lp22 & 0,26 & 0,23 & 0,19 & 0,10 & 0,07 & 0,04 & 0,01 & 0,01 & 0,00 & 0,00 & 0,00 \\
\hline$E$ & LIC11030 & Lp35 & 0,53 & 0,28 & 0,13 & 0,05 & 0,02 & 0,01 & 0,00 & 0,00 & 0,00 & 0,00 & 0,00 \\
\hline $\mathrm{F}$ & LIC11087 & Lp30 & 0,55 & 0,30 & 0,15 & 0,06 & 0,01 & 0,01 & 0,00 & 0,00 & 0,00 & 0,00 & 0,00 \\
\hline G & LigAc & LigAc & 0,52 & 0,53 & 0,58 & 0,65 & 0,65 & 0,65 & 0,46 & 0,26 & 0,13 & 0,06 & 0,03 \\
\hline $\mathrm{H}$ & FliCi & FliCi & 0,51 & 0,58 & 0,81 & 1,03 & 1,20 & 1,27 & 1,12 & 0,78 & 0,50 & 0,31 & 0,20 \\
\hline I & Bacterina & Bacterina & 0,59 & 0,45 & 0,33 & 0,24 & 0,13 & 0,05 & 0,00 & 0,01 & 0,01 & 0,01 & 0,01 \\
\hline & & & 100 & 200 & 400 & 800 & 1.600 & 3.200 & 6.400 & 12.800 & 25.600 & 51.200 & 102.400 \\
\hline & $\mathrm{Al}(\mathrm{OH}) 3$ & & 1 & 2 & 3 & 4 & 5 & 6 & 7 & 8 & 9 & 10 & 11 \\
\hline A & LIC10009 & Lp25 & 1,01 & 0,96 & 0,94 & 0,68 & 0,64 & 0,44 & 0,27 & 0,15 & 0,07 & 0,03 & 0,03 \\
\hline B & LIC10301 & Lp11 & 0,79 & 0,56 & 0,36 & 0,18 & 0,12 & 0,07 & 0,03 & 0,01 & 0,00 & 0,00 & 0,00 \\
\hline C & LIC10507 & Lp21 & 0,82 & 0,76 & 0,77 & 0,68 & 0,57 & 0,37 & 0,31 & 0,21 & 0,14 & 0,08 & 0,05 \\
\hline D & LIC10704 & Lp22 & 0,71 & 0,75 & 0,63 & 0,57 & 0,43 & 0,33 & 0,20 & 0,11 & 0,06 & 0,03 & 0,02 \\
\hline$E$ & LIC11030 & Lp35 & 0,37 & 0,40 & 0,17 & 0,21 & 0,39 & 0,31 & 0,25 & 0,13 & 0,08 & 0,04 & 0,03 \\
\hline $\mathrm{F}$ & LIC11087 & Lp30 & 0,41 & 0,39 & 0,37 & 0,17 & 0,05 & 0,17 & 0,16 & 0,13 & 0,09 & 0,04 & 0,03 \\
\hline G & LigAc & LigAc & 0,51 & 0,51 & 0,57 & 0,42 & 0,29 & 0,20 & 0,13 & 0,09 & 0,06 & 0,04 & 0,02 \\
\hline $\mathrm{H}$ & FliCi & FliCi & $0,03^{\prime}$ & $0,02^{r}$ & $0,03^{\circ}$ & $0,00^{\prime}$ & $0,00^{\prime \prime}$ & $0,00^{\circ}$ & $0,00^{\circ}$ & $0,00^{\prime}$ & $0,00^{\prime}$ & $0,00^{\prime}$ & 0,00 \\
\hline I & Bacterina & Bacterina & 0,61 & 0,54 & 0,35 & 0,27 & 0,17 & 0,12 & 0,07 & 0,05 & 0,04 & 0,02 & 0,02 \\
\hline & & & 100 & 200 & 400 & 800 & 1.600 & 3.200 & 6.400 & 12.800 & 25.600 & 51.200 & 102.400 \\
\hline & FliCi & & 1 & 2 & 3 & 4 & 5 & 6 & 7 & 8 & 9 & 10 & 11 \\
\hline A & LIC10009 & Lp25 & 0,09 & 0,09 & 0,07 & 0,02 & 0,00 & 0,00 & 0,00 & 0,00 & 0,00 & 0,00 & 0,00 \\
\hline B & LIC10301 & Lp11 & 0,84 & 0,91 & 0,86 & 0,55 & 0,33 & 0,14 & 0,06 & 0,01 & 0,00 & 0,00 & 0,00 \\
\hline C & LIC10507 & Lp21 & 0,52 & 0,58 & 0,73 & 0,88 & 0,84 & 0,74 & 0,59 & 0,39 & 0,21 & 0,10 & 0,06 \\
\hline D & LIC10704 & Lp22 & 0,33 & 0,31 & 0,30 & 0,29 & 0,23 & 0,14 & 0,08 & 0,05 & 0,03 & 0,02 & 0,01 \\
\hline$E$ & LIC11030 & Lp35 & 0,57 & 0,51 & 0,67 & 0,51 & 0,36 & 0,16 & 0,01 & 0,03 & 0,00 & 0,02 & 0,01 \\
\hline $\mathrm{F}$ & LIC11087 & Lp30 & 0,46 & 0,55 & 0,39 & 0,32 & 0,15 & 0,04 & 0,06 & 0,06 & 0,03 & 0,03 & 0,01 \\
\hline G & LigAc & LigAc & 0,64 & 0,59 & 0,58 & 0,52 & 0,43 & 0,24 & 0,12 & 0,03 & 0,01 & 0,02 & 0,03 \\
\hline $\mathrm{H}$ & FliCi & FliCi & 0,43 & 0,52 & 0,62 & 0,83 & 1,00 & 1,00 & 0,82 & 0,50 & 0,29 & 0,14 & 0,05 \\
\hline 1 & Bacterina & Bacterina & 0,45 & 0,48 & 0,40 & 0,52 & 0,39 & 0,26 & 0,12 & 0,06 & 0,03 & 0,03 & 0,01 \\
\hline & & & 100 & 200 & 400 & 800 & 1.600 & 3.200 & 6.400 & 12.800 & 25.600 & 51.200 & 102.400 \\
\hline
\end{tabular}




\begin{tabular}{|c|c|c|c|c|c|c|c|c|c|c|c|c|c|}
\hline \multicolumn{3}{|c|}{ 11) Pool + Lig A + Al(OH)3 } & \multirow{2}{*}{$\begin{array}{r}1 \\
0,99\end{array}$} & \multirow{2}{*}{$\begin{array}{r}2 \\
0,91\end{array}$} & \multirow{2}{*}{$\begin{array}{r}3 \\
0,79\end{array}$} & \multirow{2}{*}{$\begin{array}{r}4 \\
0,58\end{array}$} & \multirow{2}{*}{$\begin{array}{r}5 \\
0,56\end{array}$} & \multirow{2}{*}{$\begin{array}{r}6 \\
0,36\end{array}$} & \multirow{2}{*}{$\begin{array}{r}7 \\
0,23\end{array}$} & \multirow{2}{*}{$\begin{array}{r}8 \\
0,11\end{array}$} & \multirow{2}{*}{$\begin{array}{r}9 \\
0,06\end{array}$} & \multirow{2}{*}{$\begin{array}{r}10 \\
0,03\end{array}$} & \multirow{2}{*}{$\begin{array}{r}11 \\
0,02\end{array}$} \\
\hline A & LIC10009 & Lp25 & & & & & & & & & & & \\
\hline C & LIC10507 & Lp21 & 0,39 & 0,35 & 0,18 & 0,09 & 0,02 & 0,02 & 0,02 & 0,02 & 0,03 & 0,01 & 0,01 \\
\hline $\mathrm{E}$ & LIC11030 & Lp35 & 0,33 & 0,17 & 0,07 & 0,11 & 0,24 & 0,18 & 0,11 & 0,07 & 0,03 & 0,02 & 0,01 \\
\hline $\mathrm{F}$ & LIC11087 & Lp30 & 0,38 & 0,37 & 0,45 & 0,30 & 0,15 & 0,08 & 0,02 & 0,02 & 0,03 & 0,02 & 0,01 \\
\hline G & LigAc & LigAc & $0,19^{\prime}$ & $0,26^{\prime}$ & $0,32^{\top}$ & $0,44^{\top}$ & $0,50^{\prime}$ & $0,58^{\prime}$ & $0,57^{\prime}$ & $0,49^{\prime}$ & $0,33^{\prime}$ & $0,21^{\top}$ & 0,10 \\
\hline \multirow{2}{*}{1} & & & 100 & 200 & 400 & 800 & 1.600 & 3.200 & 6.400 & 12.800 & 25.600 & 51.200 & 102.400 \\
\hline & & & & & & & & & & & & & \\
\hline \multicolumn{3}{|c|}{ 12) Pool + Lig A + FliCi } & 1 & 2 & 3 & 4 & 5 & 6 & 7 & 8 & 9 & 10 & 11 \\
\hline A & LIC10009 & Lp25 & 1,02 & 1,05 & 0,98 & 0,54 & 0,41 & 0,20 & 0,08 & 0,05 & 0,01 & 0,00 & 0,00 \\
\hline B & LIC10301 & Lp11 & 0,02 & 0,10 & 0,25 & 0,35 & 0,30 & 0,28 & 0,17 & 0,09 & 0,04 & 0,03 & 0,02 \\
\hline G & LigAc & LigAc & 0,27 & 0,31 & 0,29 & 0,38 & 0,42 & 0,49 & 0,38 & 0,23 & 0,13 & 0,07 & 0,04 \\
\hline $\mathrm{H}$ & FliCi & FliCi & 0,29 & 0,36 & 0,43 & 0,64 & 0,85 & 0,91 & 0,86 & 0,48 & 0,37 & 0,21 & 0,10 \\
\hline \multirow[t]{2}{*}{1} & Bacterina & Bacterina & 0,45 & 0,32 & 0,10 & 0,01 & 0,02 & 0,03 & 0,02 & 0,01 & 0,02 & 0,01 & 0,01 \\
\hline & & & 100 & 200 & 400 & 800 & 1.600 & 3.200 & 6.400 & 12.800 & 25.600 & 51.200 & 102.400 \\
\hline
\end{tabular}

